Portland State University

PDXScholar

1994

\title{
Source rock geochemistry of the southern Tyee Basin, southwest Oregon
}

David E. Long

Portland State University

Follow this and additional works at: https://pdxscholar.library.pdx.edu/open_access_etds

Part of the Geology Commons

Let us know how access to this document benefits you.

Recommended Citation

Long, David E., "Source rock geochemistry of the southern Tyee Basin, southwest Oregon" (1994).

Dissertations and Theses. Paper 4040.

https://doi.org/10.15760/etd.5924

This Thesis is brought to you for free and open access. It has been accepted for inclusion in Dissertations and Theses by an authorized administrator of PDXScholar. Please contact us if we can make this document more accessible: pdxscholar@pdx.edu. 


\section{THESIS APPROVAL}

The abstract and thesis of David E. Long for the Master of Science degree in Geology were presented May 12, 1994, and accepted by the thesis committee and the department.

COMMITTEE APPROVALS:

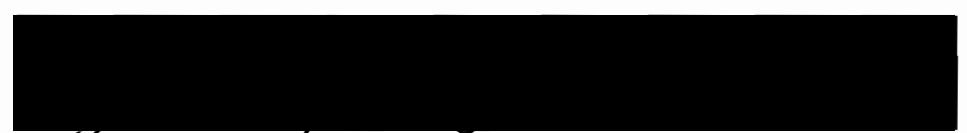

Richard E. Thoms, Chair

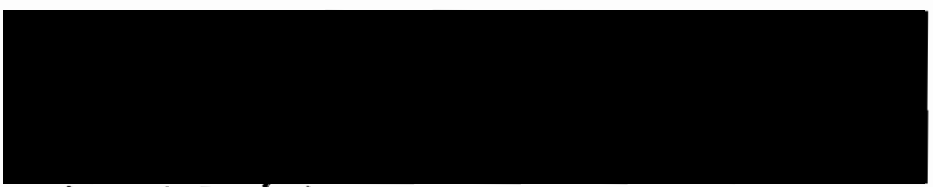

Ansel G. Johnson

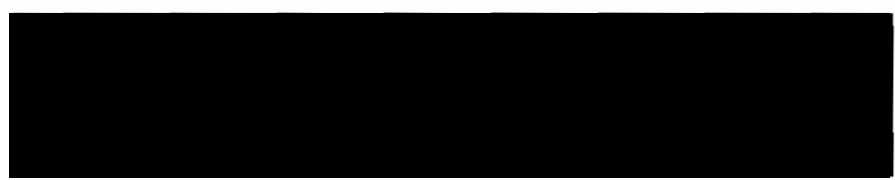

Scott F. Burns

DEPARTMENT APPROVAL:

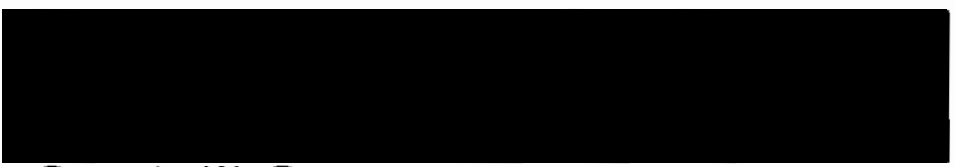

Dennis W. Barnum

Representative of the Office of Graduate Studies

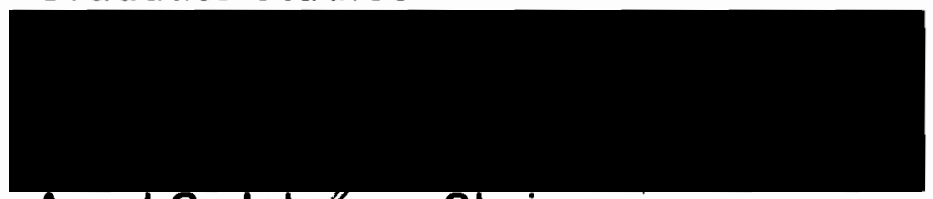

Ansel G. Johorson, Chair

Department of Geology

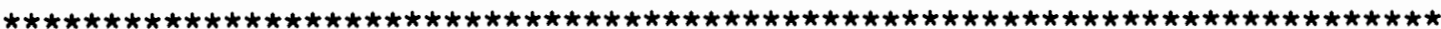

ACCEPTED FOR PORTLAND STATE UNIVERSITY BY THE LIBRARY

by 


\section{ABSTRACT}

An abstract of the thesis of David E. Long for the Master of Science in Geology presented May 12, 1994.

Title: Source Rock Geochemistry of the Southern Tyee Basin, Southwest Oregon.

This study examined source rock geochemistry of the southern Tyee Basin. Total organic carbon, rock-eval pyrolysis, vitrinite reflectance, thermal alteration index and visual assessments were performed on splits from cutting samples from five wells and on outcrop samples from four measured sections. Organic matter was found to be dispersed, averaging about 0.5 weight percent. The organic matter is primarily terrestrial in origin, or type III, with low potential for gas production and no oil potential. Three coal samples are clearly the richest sources of organic matter examined in this study.

Maturity of all samples is low. The most mature samples are near or possibly just within the gas production window. Maturation indices indicate that most of the basin cannot be expected to contain sedimentary rocks that have matured to the point of 
producing hydrocarbons. There is a possibility of deeply buried sediments containing more mature organic matter in the southeastern part of the basin, based on the latest tectonic and stratigraphic models of the basin. While these results do not preclude the discovery of oil or gas in the Tyee basin, the encouragement they offer is limited. 
SOURCE ROCK GEOCHEMISTRY OF THE SOUTHERN

TYEE BASIN, SOUTHWEST OREGON

by

DAVID E. LONG

A thesis submitted in partial fulfillment of the requirements for the degree of

MASTER OF SCIENCE

in

GEOLOGY

Portland State University

1995 
ACKNOWLEDGEMENTS

LIST OF FIGURES

LIST OF TABLES

viii

SOURCE ROCK GEOCHEMISTRY OF THE SOUTHERN TYEE BASIN, SOUTHWEST OREGON.

INTRODUCTION

METHODS

GEOLOGY OF THE SOUTHERN TYEE BASIN

STUDY AREA

PREVIOUS WORK

STRUCTURE AND TECTONIC SETTING

STRATIGRAPHY

SEQUENCE STRATIGRAPHY

OIL AND GAS POTENTIAL OF THE SOUTHERN TYEE BASIN RESERVOIR ROCKS

POROSITY AND PERMEABILITY

58

CAP ROCKS AND SEALS

61

STRUCTURAL TRAPS 
DATA AND ANALYSIS

ORGANIC RICHNESS

CONCLUSIONS

REFERENCES

\section{APPENDICES}

APPENDIX A: Lithology and TOC Data

APPENDIX B: Rock-Eval Pyrolysis Data

APPENDIX C: Vitrinite Reflectance, Thermal Alteration Index and Visual Assessment Summary

APPENDIX D: Vitrinite Reflectance Histograms 


\section{ACKNOWLEDGEMENTS}

Everyone who contributed to the successful completion of this thesis has my sincere and heartfelt thanks. The members of my thesis committee, Dr. Richard Thoms, Dr. Ansel Johnson, Dr. Scott Burns and Dr. Dennis Barnum (all of Portland State University) provided much valuable input. I owe thanks to the entire staff of the Portland State University Geology Department for accommodating my long-running Master's degree program. Particularly I thank Dr. Richard Thoms for taking on the role of my advisor when my need for assistance was at its greatest.

I would also like to thank Wally Dow, Dolores O'Conner, and John Allen of DGSI for their willingness to spend time discussing the results of their geochemical analyses. Discussions with them were critical to the solution of numerous problems.

I owe special thanks to Dr. Alan Niem (Oregon State University) and to In-Chang Ryu (doctoral candidate, Oregon State University). Dr. Niem generously offered me a role in their ongoing project and shared his knowledge of the geology of the Tyee basin. In-Chang Ryu gave freely of his time, his ideas and his data, all of which were indispensable to the completion of this project. Their guidance assured that my work could be usefully integrated with theirs while still standing on its own, a balancing act which could not have succeeded without them. I relied heavily on their work, and their input and review was critical. 
Finally I would like to thank my family, whose patience and support have been vital to the completion of this project. 


\section{LIST OF FIGURES}

FIGURE

1 Location map for the southern Tyee basin.

2 Location of sampled exploration wells and measured sections.

3 The evolution of organic matter in sediments.

4 Redistribution of hydrogen during maturation.

5 Kerogen evolution pathways.

6 Rate of gas release vs time during rock-eval pyrolysis.

7 Units in the study area (nomenclature of Baldwin, 1974).

8 Simplified tectonic model of the Oregon Coast Range.

9 Depotectonic setting of Eocene rock units.

10 General geology and tectonic features of the southern Tyee Basin.

11 Stratigraphic nomenclature for the southern Tyee Basin.

12 Distribution of the Tyee Formation and the Umpqua Group.

13 Lowstand systems tract: fan deposition.

14 Lowstand systems tract: wedge deposition.

15 Transgressive systems tract.

16 Highstand systems tract.

17 Comparison of chronostratigraphic correlation to lithostratigraphic correlation: retrogradational parasequence set. 
18 TOC and HI vs Depth for Great Discovery 2 well.

19 TOC and HI vs Depth for Long Bell 1 well.

20 TOC and HI vs Depth for Liles 1 well.

21 TOC and HI vs Depth for Scott 1 well.

22 TOC and HI vs Depth for Glory Hole 1 well.

23 TOC and $\mathrm{HI}$ vs Elevation in Section for measured section 7 .

24 HI vs OI for all samples.

25 Correlation chart for maturation indices.

26 Tmax, Ro and PI vs Depth for Liles 1 well.

27 Tmax excluding interbeds, Tmax including interbeds and Ro vs Depth for Long Bell 1 well.

28 Extrapolated Tmax, restricted Ro and PI vs Depth for Long Bell 1 well.

29 Tmax, Ro and PI vs Depth for Scott 1 well.

30 Tmax, Ro and PI vs Depth for Great

Discovery 2 well.

31 Tmax, Ro and PI vs Depth for Glory Hole 1 well.

32 Tmax and PI vs Elevation in Section for measured section 7 .

33 T max, Ro and PI vs Elevation for coal samples. 


\section{LIST OF TABLES}

TABLE

PAGE

1 Exploration Wells in the Southern Tyee Basin.

2 Kerogen Classification.

3 Macerals, Kerogen Type and Organic Precursors.

4 Porosity and Permeability of Outcrop Samples.

5 Average TOC.

6 Average Hydrogen Index.

7 Source Potential from Hydrogen Index.

8 Source Potential from TOC.

9 Systematic Variations in Tmax Data. 


\section{SOURCE ROCK GEOCHEMISTRY OF THE SOUTHERN}

TYEE BASIN, SOUTHWEST OREGON.

\section{INTRODUCTION}

Sedimentary basins associated with convergent plate boundaries have become targets for oil and gas exploration in many parts of the world. Advances in sequence stratigraphy (Van Wagoner and others, 1990), basin analysis (Robert, 1985) and organic geochemistry (Tissot and Welte, 1984) have served to improve understanding of the nature of oil and gas accumulations in these tectonically complex regions.

The Oregon Coast Range sediments are a good candidate for oil and gas investigation at a convergent boundary. Thick sedimentary sections contain plentiful traps and reservoir sands (Armentrout and Suek, 1985; Niem and Niem, 1990). The quality of potential source rocks is more questionable, but commercial quantities of gas have been found in the Clark and Wilson Sand of the Cowlitz Formation in the northwest Oregon Coast Range (Armentrout and Suek, 1985).

Based on the advances and improvements in the available database for the region, a re-examination of the early to middle 


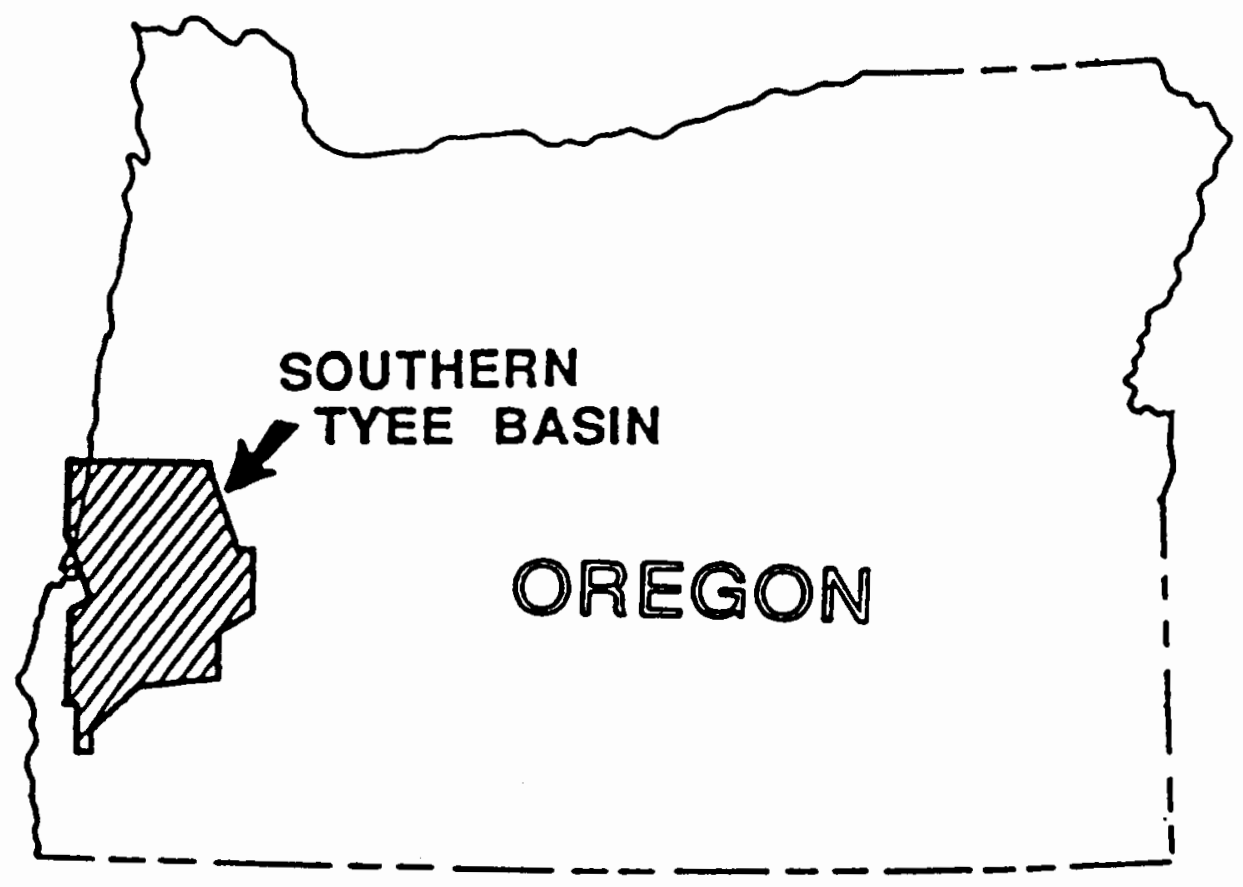

Figure 1: Location map for the southern Tyee basin. (Ryu and others, 1992)

Eocene section in the southern Tyee basin (fig. 1) has been undertaken (Ryu and Niem, 1993). Ryu (personal communication, 1994) has attempted to settle the recent disagreement on depositional models for the sedimentary section caused by divergent stratigraphic interpretations of different workers (Baldwin, 1974; Chan and Dott, 1983; Molenaar, 1985; Heller and Dickinson, 1985). Ryu is also analyzing porosity and permeability and studying the diagenesis of sediments in the basin (I.-C. Ryu, personal communication, 1994). Detailed new mapping by Black 
(1990, 1993) and ongoing projects led by G. Black and R. Wells (A. Niem, personal communication, 1994) have clarified structural and stratigraphic relationships and have led to revisions of the stratigraphic nomenclature for the region.

This study utilized the improved understanding of the basin to target locations where source rock organic geochemical data would be of value in an assessment of the oil and gas potential of the basin, supplementing the limited data already available. The majority of the available organic geochemical data are from surface samples of the undifferentiated Umpqua Group turbidite fan strata, and the Upper Jurassic-Lower Cretaceous Myrtle Group of the Klamath Mountains (Niem and Niem, 1990). Both were sampled over very limited areas. Niem and Niem (1990) point out that the data may not be a representative sample of all the source rock units in the basin. Furthermore, improvements in the mapping, stratigraphy and depositional interpretations for the basin have resulted from the projects led by I.-C. Ryu (personal communication, 1994), A. Niem, G. Black and R. Wells (A. Niem, personal communication, 1994). These factors have given impetus for this study.

The organic geochemical data of this study will be integrated with the results of the ongoing studies described above in the most thorough examination to date of the hydrocarbon potential of the Tyee basin (A. Niem, personal communication, 1994). 


\section{METHODS}

This project began with review of prior studies of the Tyee basin. Emphasis was on studies which included source rock geochemical data. Sampling for this study was designed to supplement the existing source rock data. Sampling was also planned to take advantage of refinements to the mapping and stratigraphic interpretation of the basin by sampling previously unmapped units.

Samples were selected from two sources. The first source was well cuttings from oil and gas exploratory wells. Table 1 lists, with the pertinent data, the twenty oil and gas exploratory wells drilled in the area. Cuttings from five of these wells have been used in this study (fig. 2). The second source was outcrop samples from selected measured sections used in the stratigraphic study of the basin (fig. 2) (Ryu and others, 1992). A total of fifty-one samples were selected for analysis for this study: 38 from well cuttings and 13 from outcrop samples. Rock-eval pyrolysis (Tissot and Welte, 1984) and total organic carbon (TOC) analyses (Hunt, 1979) were performed on all 51 samples by DGSI Labs. Results are tabulated (Appendices $A$ and $B$ ) by well or measured section number as designated on the index map (fig. 2) and in Table 1. Rock-eval pyrolysis and TOC analyses were done on an additional 144 samples, 108 from outcrops and 36 from well cuttings, by the US Geological Survey (USGS) lab in Denver, Colorado. Results from 13 


\begin{tabular}{|c|c|c|c|c|c|c|}
\hline No & D. NAME & OPERATOR & $\underset{\text { (ft) }}{\text { DEF }}$ & $\begin{array}{l}\text { TH } \\
(m)\end{array}$ & LOCATION & DATE \\
\hline 1 & Long Bell 1 & $\begin{array}{l}\text { General } \\
\text { Petroleum }\end{array}$ & 9004 & 2701 & SW $1 / 4 \sec 27, T 20 S, R 10 W$ & 1957 \\
\hline 2 & Well No. 1-4 & $\begin{array}{l}\text { Florida } \\
\text { Exploration }\end{array}$ & 5962 & 1789 & NE $1 / 4 \sec 4, T 21 \mathrm{~S}, \mathrm{R} 6 \mathrm{~W}$ & 1982 \\
\hline 3 & $\begin{array}{l}\text { Sawyer } \\
\text { Rapids } 1\end{array}$ & $\begin{array}{l}\text { Northwest } \\
\text { Exploration }\end{array}$ & 5562 & 1669 & NE $1 / 4 \sec 3, T 23 \mathrm{~S}, \mathrm{R} 9 \mathrm{~W}$ & 1980 \\
\hline 4 & $\begin{array}{l}\text { Weyerhauser } \\
\text { F-1 }\end{array}$ & $\begin{array}{l}\text { Amoco } \\
\text { Production }\end{array}$ & 4401 & 1320 & NE $1 / 4 \mathrm{sec} 10, \mathrm{~T} 25 \mathrm{~S}, \mathrm{R} 1 \mathrm{OW}$ & 1985 \\
\hline 5 & $\begin{array}{l}\text { Weyerhauser } \\
\text { B-1 }\end{array}$ & $\begin{array}{l}\text { Amoco } \\
\text { Production }\end{array}$ & 11,330 & 3399 & SE $1 / 4 \sec 13$, T25S, R9W & 1985 \\
\hline 6 & Oakland & Clark & 2235 & 671 & NE $1 / 4 \sec 8, T 25 S, R 5 W$ & 1926 \\
\hline 7 & $\begin{array}{l}\text { Sutherlin } \\
\text { Unit } 1\end{array}$ & Mobil & 13,177 & 3953 & SW $1 / 4 \sec 36, T 24 S, R 5 W$ & 1979 \\
\hline 8 & Liles 1 & Union & 7002 & 2101 & SE $1 / 4$ sec $27, T 25 S, R 7 W$ & 1951 \\
\hline 9 & Glory Hole 1 & $\begin{array}{l}\text { Hutchins } \\
\text { and Marrs }\end{array}$ & 2987 & 896 & $N W 1 / 4 \sec 20, T 30 S, R 9 W$ & 1983 \\
\hline 10 & $S \operatorname{cott} 1$ & $\begin{array}{l}\text { Community } \\
\text { Oil and Gas }\end{array}$ & 3693 & 1108 & SW $1 / 4 \sec 5, T 27 \mathrm{~S}, \mathrm{R} 6 \mathrm{~W}$ & 1954 \\
\hline 11 & $\begin{array}{l}\text { Hamilton } \\
\text { Ranch } 1\end{array}$ & Diamond Drill & 628 & 188 & $N W 1 / 4 \sec 12, T 27 S, R 7 W$ & 1910 \\
\hline 12 & $\begin{array}{l}\text { Hamilton } \\
\text { Ranch } 2\end{array}$ & Diamond Drill & 1109 & 333 & $N W 1 / 4 \sec 34, T 27 S, R 7 W$ & 1910 \\
\hline 13 & $\begin{array}{l}\text { Hamilton } \\
\text { Ranch } 3\end{array}$ & Diamond Drill & 545 & 164 & SE $1 / 4$ sec 14, T27S, R7W & 1910 \\
\hline 14 & Well No. 1 & Kernin & 3900 & 1170 & NE $1 / 4$ sec 23, T27S, R6W & 1931 \\
\hline 15 & Unnamed & Dillard & 700 & 210 & NE $1 / 4 \sec 6, T 28 S, R 7 W$ & 1910 \\
\hline 16 & Ziedrich 1 & Uranium Oil \& Gas & 54368 & 1310 & NW $1 / 4 \sec 16, T 29 S, R 8 W$ & 1955 \\
\hline 17 & $\begin{array}{l}\text { Great } \\
\text { Discovery } 2\end{array}$ & $\begin{array}{l}\text { Hutchins } \\
\text { and Marrs }\end{array}$ & 3510 & 1053 & NW $1 / 4 \sec 20, T 30 S$, R9W & $?$ \\
\hline 18 & Wollenberg 1 & $\begin{array}{l}\text { Riddle Gas } \\
\& \text { Oil Prod. }\end{array}$ & 1100 & 330 & NE $1 / 4$ sec $28, T 30 \mathrm{~S}, \mathrm{R} 6 \mathrm{~W}$ & 1965 \\
\hline 19 & Aikens 1 & $\begin{array}{l}\text { Riddle Gas } \\
\& \text { Oil Prod. }\end{array}$ & 480 & 144 & SE $1 / 4$ sec $27, T 30 S, R 6 W$ & 1960 \\
\hline 20 & Dayton 1 & $\begin{array}{l}\text { Riddle Gas } \\
\text { \& Oll Prod. }\end{array}$ & 1370 & 411 & SW $1 / 4$ sec $34, T 30 S, R 6 W$ & 1958 \\
\hline
\end{tabular}




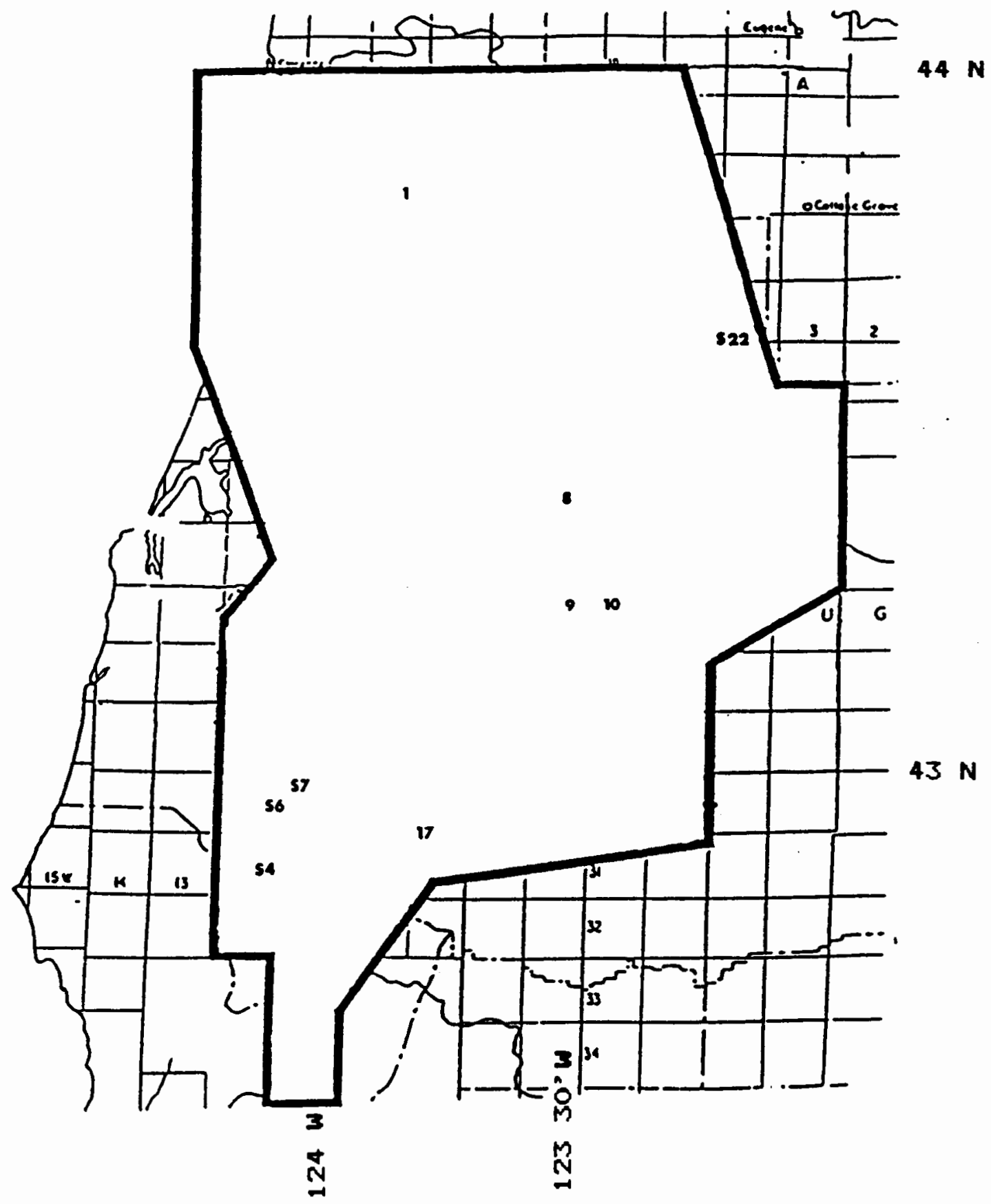

Figure 2: Location of sampled exploration wells and measured sections. (modified from Ryu unpubl.) Well numbers are from Table 1.

S4: Measured section 4 (Sand Rock Mtn.).

S6: Measured section 6 (Rasler Creek).

S7: Composite measured section 7 (Sandy Creek and Remote).

S22: Measured section $22(1-5)$. 
of these USGS samples are included in this study and are also compiled in Appendices A and B.

Using the two rock-eval pyrolysis data sets, samples for possible further analysis were prioritized based on geographic and stratigraphic distribution and quality of pyrolysis data. Budgetary constraints allowed for analysis of 20 of these samples. Vitrinite reflectance (Ro) (Robert,1988), thermal alteration index (TAI) (Engels and Macko, 1993), and visual kerogen assessment (Engels and Macko, 1993) were performed. In addition, the USGS determined vitrinite reflectance on 12 samples from the Long Bell 1 well. Ro, TAl and a summary of the visual assessment data are compiled in Appendix C. More detailed vitrinite reflectance and visual assessment data are compiled in Appendices $D$ and $E$ respectively. The remainder of the USGS data set will be available in later publications on the oil and gas potential of the Tyee basin (P. Lilles, personal communication, 1994; A. Niem, personal communication, 1994).

Well cutting samples were cleaned of obvious contaminants but were not "picked" to remove all cavings or mixed-in nonsource rock material. This could have resulted in some dilution of the source rock and lowering of TOC values in cases where caving did occur. On the other hand, it prevents the biasing of samples where a mixture of lithologies in the cuttings represents fine bedding or laminations rather than caving. This is not a problem with outcrop samples, and the fact that outcrop and cutting samples 
have produced concordant results suggests that mixing was not significant.

Rock-eval pyrolysis data and TOC were determined using Delsi Rock-Eval II units in both DGSI and USGS labs. Vitrinite reflectance, TAI, and visual kerogen assessment were performed by both labs using standard microscopy techniques. Detailed descriptions and discussions concerning these techniques are available from a variety of sources (Rock-eval pyrolysis and TOC: Hunt, 1979; Tissot and Welte, 1984; Powell and others, 1982; Peters, 1986; Microscopy: Engels and Macko, 1993; Robert, 1988). These analyses provide data concerning a variety of source rock parameters, discussed below. Data assessment has involved evaluation of source rock parameters and integration with the structural and stratigraphic data for the basin.

Sufficient quantities of organic matter must be present before a rock can be considered a potential source rock. Generally, 0.5 weight percent organic matter $(0.4 \mathrm{wt} \%$ organic carbon) is considered a minimum value (Dow, 1977b). Shales can range as high as $15 \%$ organic matter, but average about one percent (Hunt, 1972). Of that organic matter about $90 \%$ is kerogen, which is defined as the fraction that is insoluble in organic acids, and the remainder is soluble bitumens (fig. 3) (Hunt, 1979). As temperature increases with increasing burial, large kerogen molecules are broken apart, producing more bitumen. The residual kerogen 


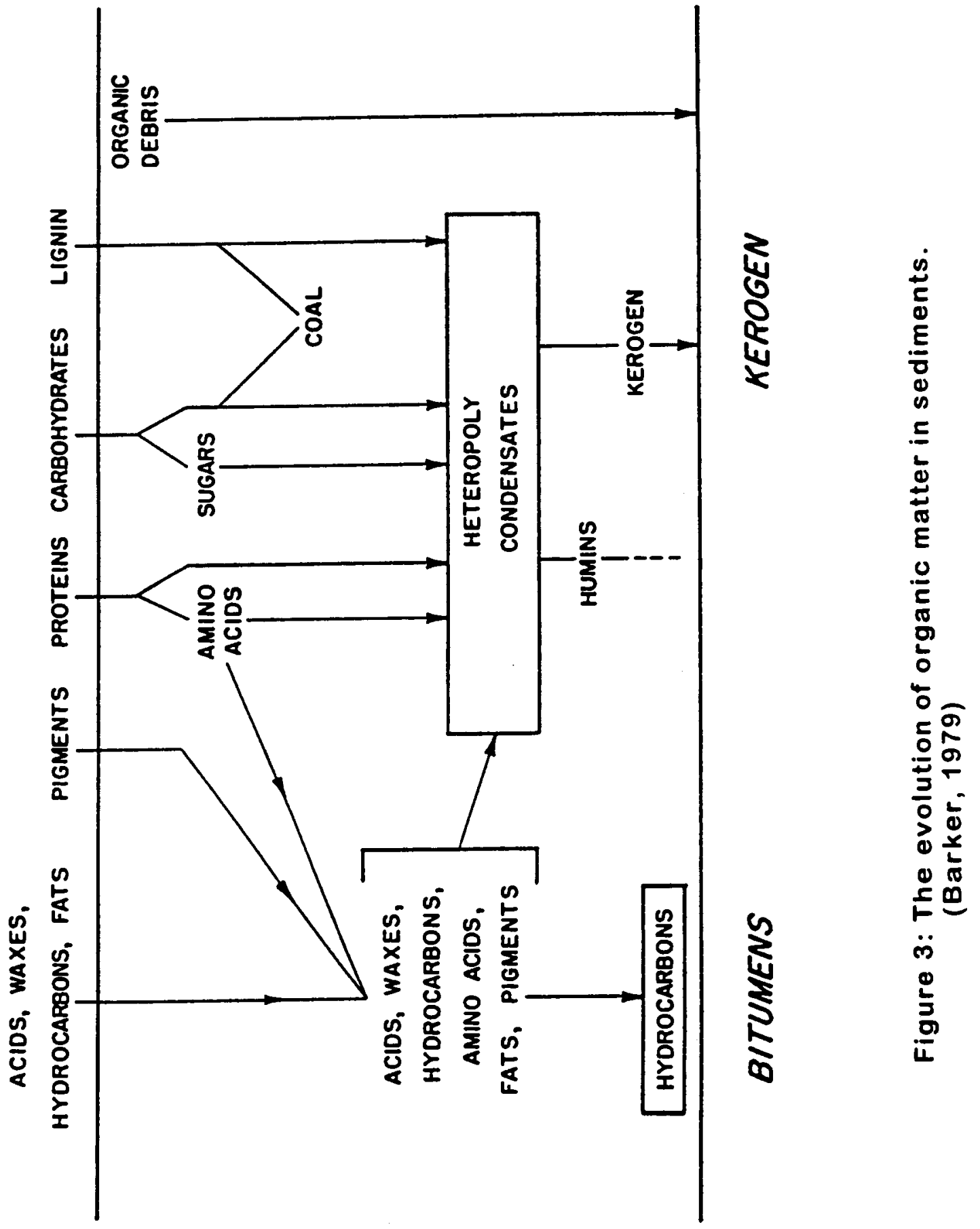


becomes more carbon rich due to loss of hydrogen and the bitumen accumulates as oil and gas (fig. 4) (Barker, 1979).

The ability of kerogen to produce hydrocarbons, as well as the type of hydrocarbons produced, is in part dependent on the nature of the original organic matter. A variety of terminologies have been devised for classifying kerogen (Table 2). While terms from the various classifications are in common use for their descriptive value, the system of Espitalie and others (1977) is especially valuable for source rock characterization. They extended the ideas of Van Krevelen (1961) who used the ratios of hydrogen and oxygen to carbon to classify the organic matter in coals. By correlating Van Krevelen's atomic ratio classification to the data derived from rockeval pyrolysis (discussed below), they were able to classify kerogen according to the type of the original organic matter, predict its evolutionary pathway with continued maturation, and thereby predict the quantity and relative proportions of its products (fig. 5).

Because the changes in kerogen play such an important role in the generation of hydrocarbons, and because kerogen is the most abundant organic matter in rocks, documenting the state of the kerogen in a sample has become an important part of source rock evaluation. Measurable kerogen parameters include changes in color, reflectance, and hydrogen, oxygen and carbon content. These data can be evaluated both individually and in combination to derive information about the source or type of the organic matter, 


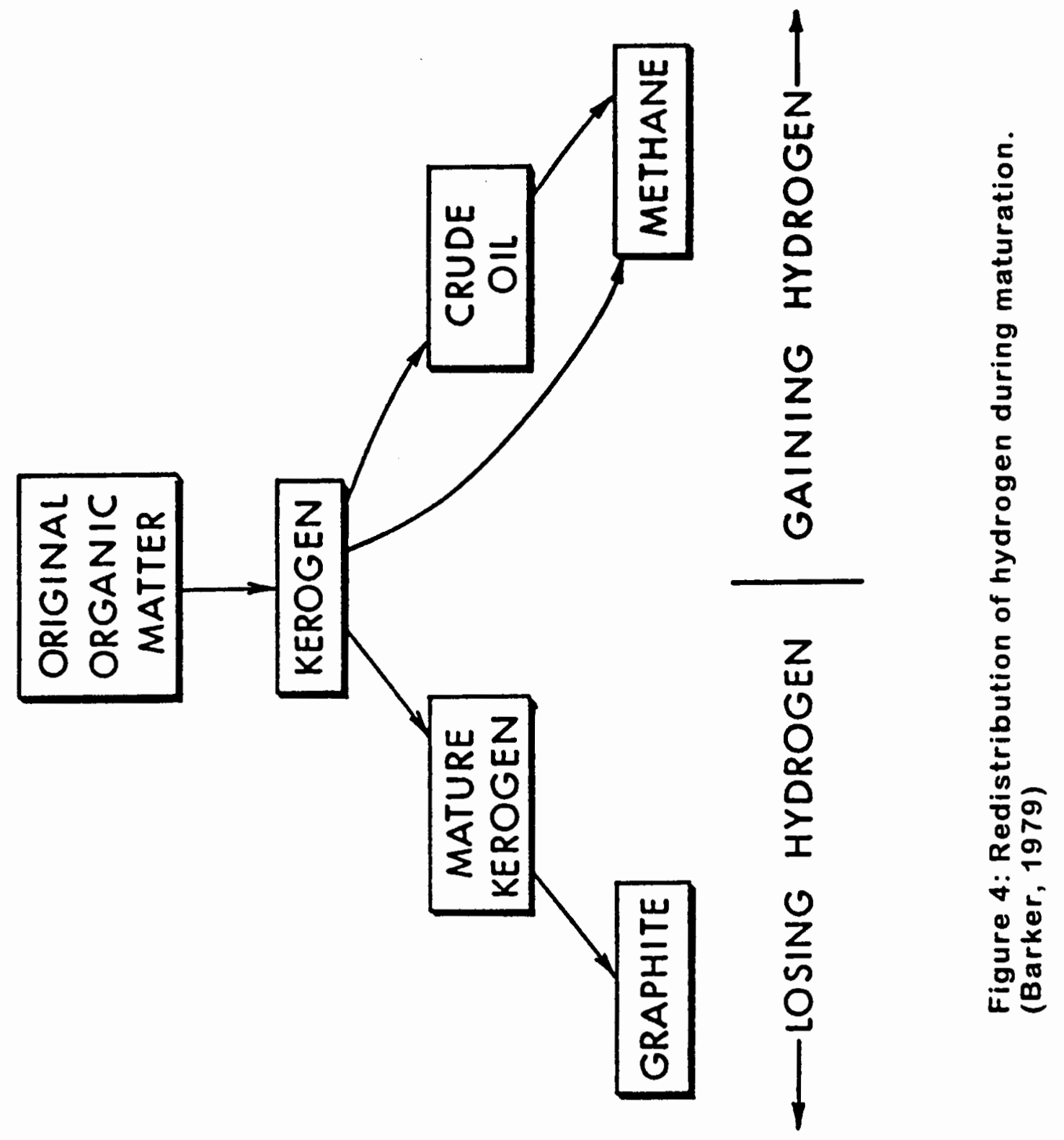


TABLE 2: KEROGEN CLASSIFICATION:

Correlation of terminologies.

(revised from Tissot and Welte, 1984)

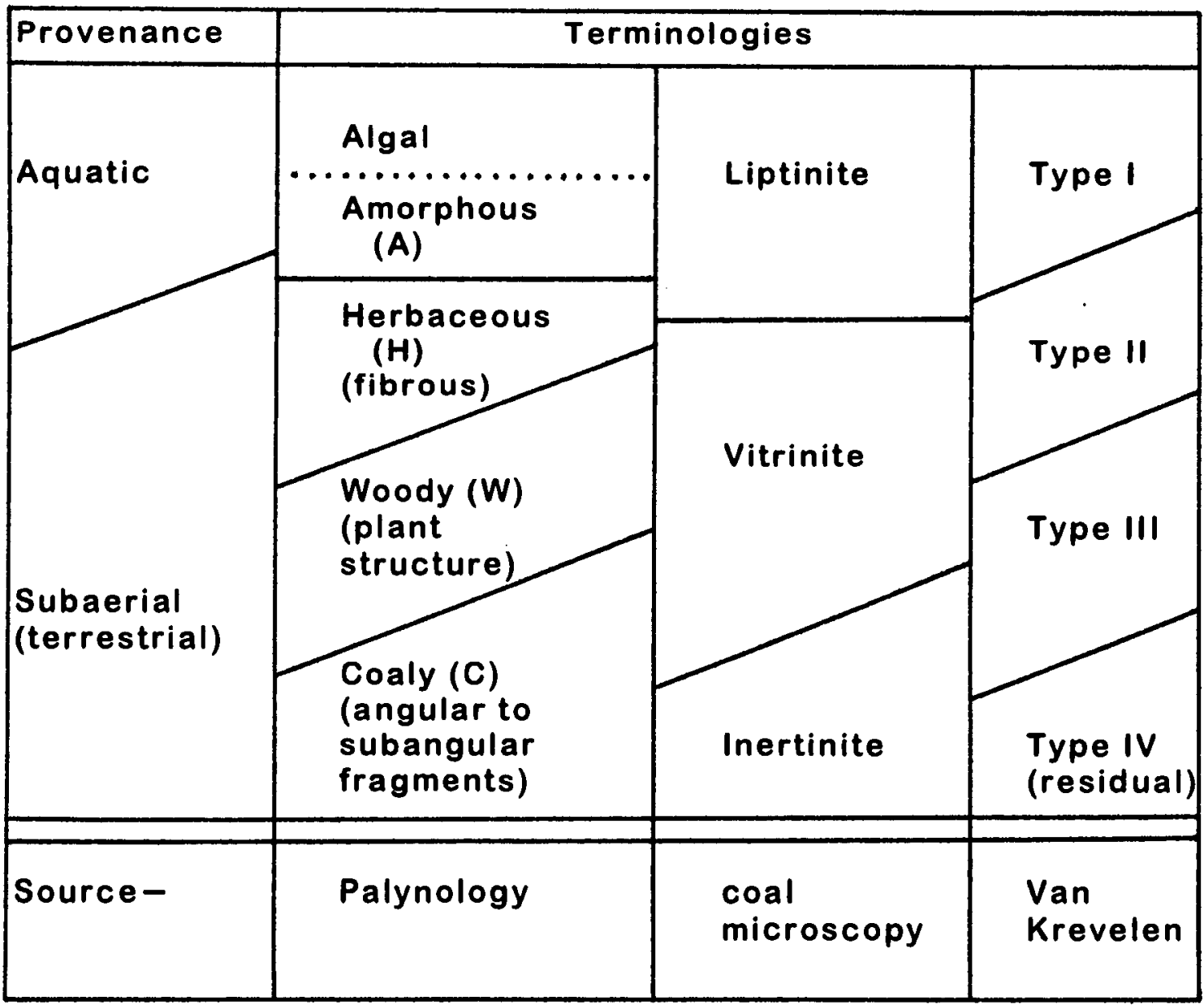

its level of maturation, and its ability to generate more hydrocarbons.

The determination of total organic carbon (TOC) is probably the most basic type of source rock geochemical analysis. In TOC determination the sample is crushed, leached with hydrochloric acid to remove any carbonate carbon and heated in a furnace to 


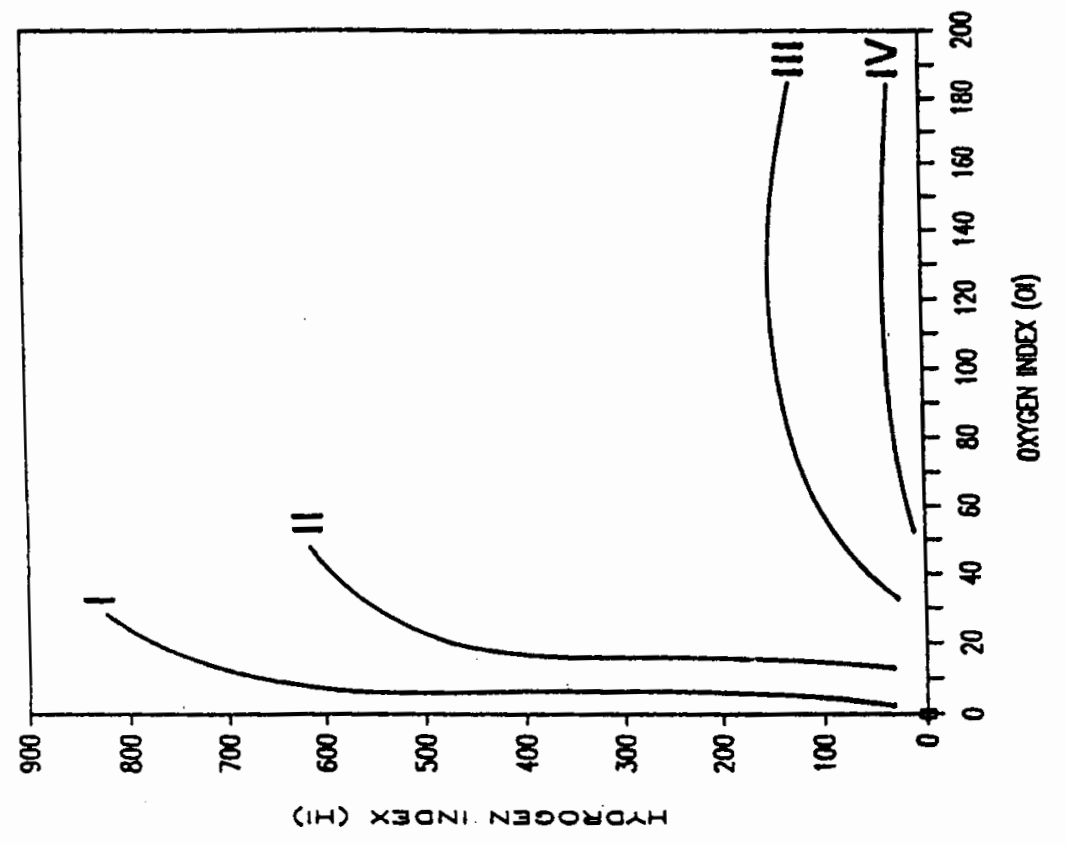

$\infty$

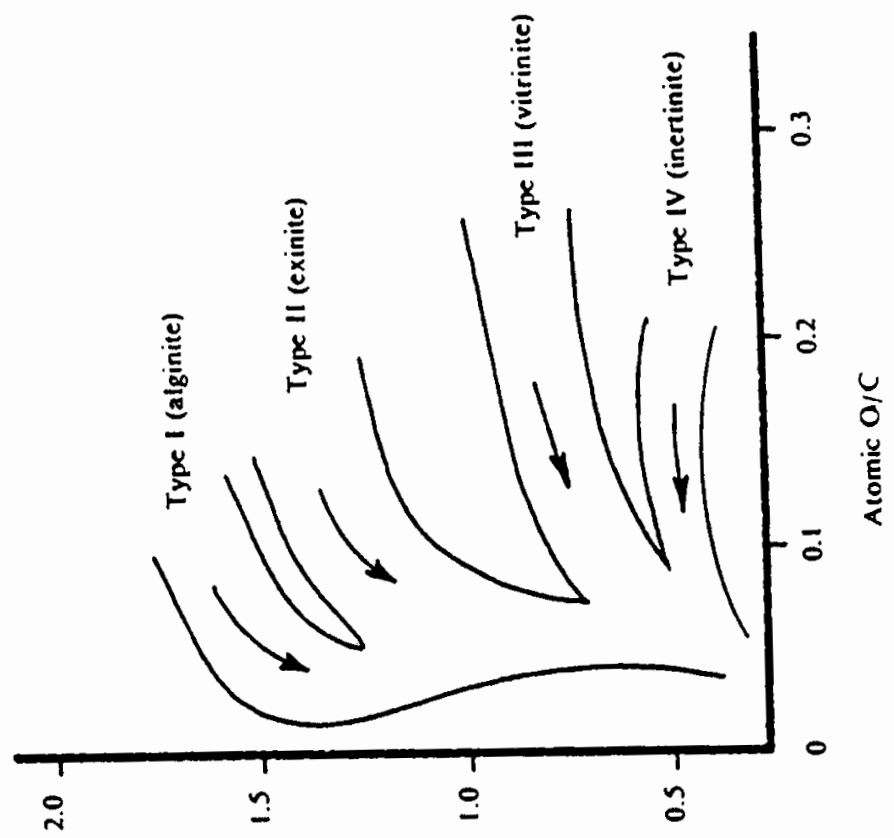


convert remaining carbon to $\mathrm{CO}$ or $\mathrm{CO}_{2}$ (Milner, 1982). The result is a measure of the total organic material in the rock. This is the total of the organic material the rock contains that could ever be converted to hydrocarbons under ideal circumstances. It provides only a rough idea of the value of the rock as a hydrocarbon source because several other factors are equally important. TOC is typically the first analysis to be done on a potential source rock because it is the simplest and cheapest to perform. Usually if TOC values are above about 0.5 wt $\%$, considered a minimal level, and sometimes even if they are not, further analysis is done (DGSI, unpubl.).

Rock-eval pyrolysis also provides a measure of the overall organic richness of the rock (Hunt, 1979). In rock-eval pyrolysis a rock is heated under controlled time and temperature conditions until all convertible hydrocarbons have been evolved as gases. The quantity and timing of the release of these gases are carefully tracked. Usually three peaks of high rates of gas release will result (fig. 6). The first (lowest) temperature peak $\left(S_{1}\right)$, represents release of organic matter that has already been converted to hydrocarbons by nature but remains in the rock. The second peak $\left(S_{2}\right)$ represents organic matter converted to hydrocarbons by the pyrolysis process, and is therefore taken to be analogous to the natural process of hydrocarbon generation. $S_{2}$ is often evaluated with TOC in the hydrogen index $(\mathrm{HI})$ as a measure of the remaining potential of the rock. The third peak $\left(S_{3}\right)$ is the release of oxygen-containing 


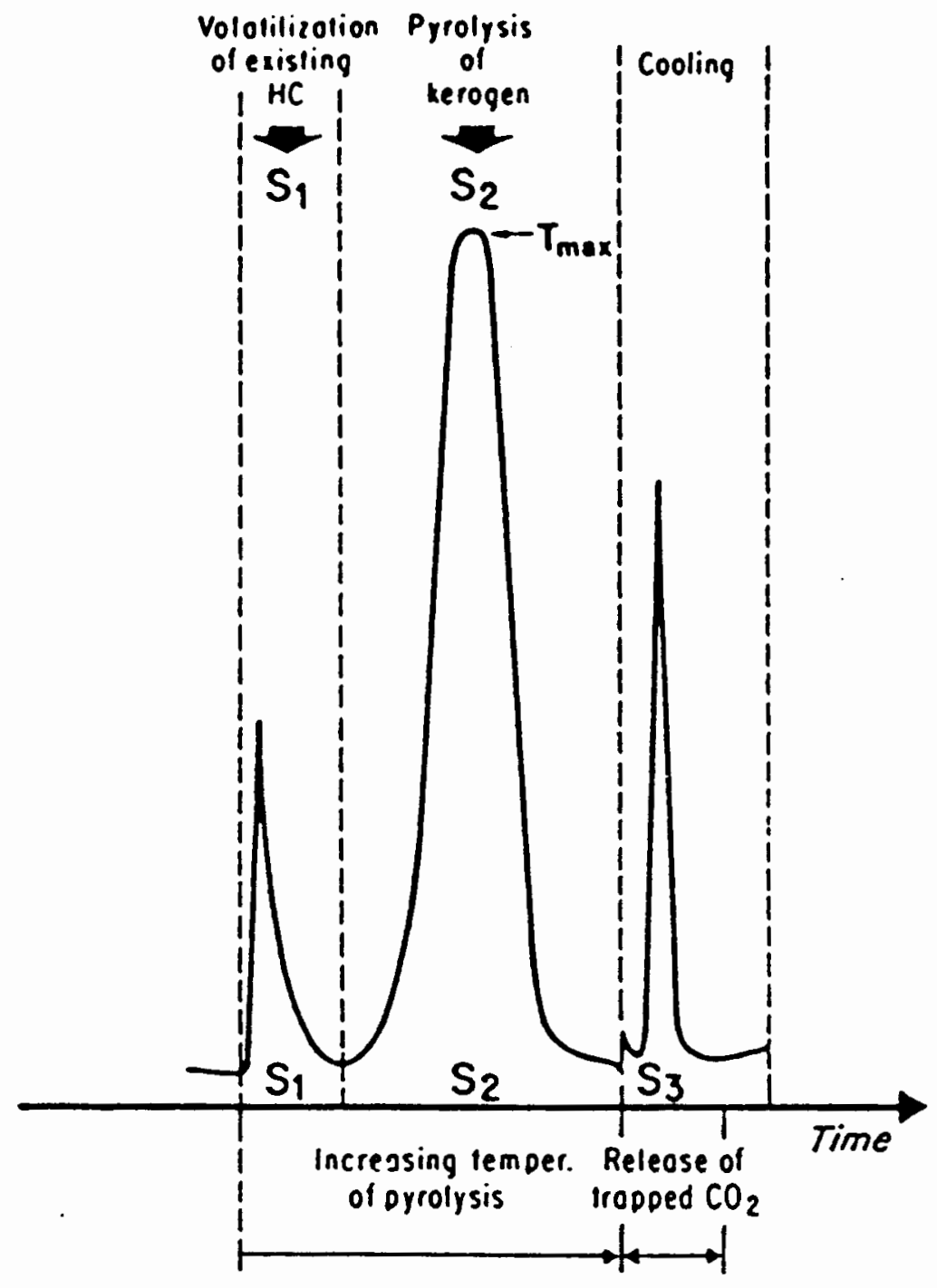

Figure 6: Rate of gas release vs time during rock-eval pyrolysis. (Hunt, 1979) 
volatiles such as $\mathrm{CO}_{2}$ (Tissot and Welte, 1984). The sum of the $S_{1}, S_{2}$ and $S_{3}$ peaks is usually less than the TOC measurement because the temperatures used are insufficient to pyrolyze all the carbon in some rocks. For example, a rock containing graphite and no other organic matter would show a large TOC but essentially no pyrolysis response (Peters, 1986).

Rock-eval pyrolysis can be applied to the determination of source rock maturity. The $S_{1}$ and $S_{2}$ peaks of pyrolysis, when evaluated together, are used to indicate the fraction of possible hydrocarbons already generated by the sample. This is evaluated using the production index (PI; formerly transformation ratio) which equals $S_{1} /\left(S_{1}+S_{2}\right)$. Generally, as maturation increases the $S_{1}$ peak increases at the expense of $S_{2}$. Also, as more of the kerogen is broken down, increasing heat is needed to cause further maturation, so the $S_{2}$ peak shifts to higher temperatures. The temperature of the mode of the $S_{2}$ peak is called Tmax. The Tmax temperature is therefore a measure of maturation by itself. It is also useful in the evaluation of whether or not hydrocarbons have been generated and already migrated out of the rock. If Tmax is high but the $S_{1}$ peak is small, hydrocarbons have probably already migrated away. Alternatively, if the $S_{2}$ peak is large and Tmax is low, substantial generative capacity must remain, whether the $S_{1}$ peak is large or small.

Oil that has migrated into the rock being analyzed can cause significant disruption of data, but its presence is usually detectable 
because it causes bimodality of the $S_{2}$ peak (Peters, 1986).

Conversely, the effects on data due to losses of oil that has formed in the rock and migrated away are normally fairly limited due to the inefficiency of source rocks in generating and releasing hydrocarbons. The amount of generated oil that migrates out of the source rock and eventually forms commercial accumulations is calculated at a maximum of $15 \%$ of the total oil that is formed, and in most cases much less (Hunt, 1977).

The use of rock-eval pyrolysis data to characterize the type of organic matter allows its classification in a general way. The hydrogen index $\left(H I=S_{2} / T O C \times 100\right)$ is the ratio of pyrolysis-generated hydrocarbons to TOC, and the oxygen index $\left(O I=S_{3} / T O C \times 100\right)$ is the ratio of oxygen-containing volatiles to TOC. These are close approximations of the $H / C$ and $O / C$ atomic ratios used by $V a n$ Krevelen (1961) to classify organic matter, and can be used in the same way. Plots of hydrogen index versus oxygen index are successfully used to classify organic matter into types I through IV as described in Figure 5 (Tissot and others, 1984). Type I through IV categorization is also an excellent indicator of the generative potential of the organic matter. The potential of terrestrial organic matter (type III) is much lower than aquatic organic matter (type 1); type 11 is intermediate. Type III is capable of producing natural gas but little or no oil (Hunt, 1979). By observing the plotted position of the sample along one of the generative pathways of the HI vs OI graph a judgment of the remaining potential of the rock can be made 
(Tissot and others, 1974). That is, the closer the sample plots to the origin of the graph the less its potential for generation of hydrocarbons. Note also that this potential is primarily due to the hydrogen index, represented by the vertical position on the graph. An evolution pathway represented by horizontal movement across the graph indicates production of oxygen and little or no hydrocarbon.

A number of studies in recent years have detailed inaccuracies of rock-eval data. It has been shown that results are influenced by a range of variables including the nature of the rock matrix (adsorption by clays if TOC is low), weathering (reduction of $S_{1}$ and $S_{2}$ peaks due to oxidation of organic matter), even sample storage time (loss of $S_{1}$ volatiles) and sample size (adsorption by equipment plumbing resulting in reduction of all peaks) (Dembicki and others, 1983; Demaison and Bourgeois, 1984; Peters, 1986). Some of these problems are easily avoidable (e.g. sample size variations), but in most cases the best course is awareness of potential problems and careful consideration of possible complicating circumstances when evaluating data. Rock-eval pyrolysis is now more frequently being used as a logging tool, often at the well site, to provide data for all or most of the drilled interval. It is followed up with microscopic analyses such as visual kerogen assessment, vitrinite reflectance and thermal alteration index. These techniques provide independent measurements for verification and more detailed analysis (DGSI, unpubl.). 
Source rock maturity evaluation is an attempt to determine how much natural maturation has occurred up to the present time. Probably the most commonly applied technique is the examination of vitrinite reflectance (Sweeney and Burnham, 1990). Vitrinite is a component of organic matter derived from woody tissue of land plants. Vitrinite reflectance is determined microscopically by measuring the proportion of light reflected from individual particles, using a detector calibrated to the reflectance in oil standard (Ro) (DGSI, unpubI.). Vitrinite increases in reflectivity with increasing thermal maturation. Vitrinite reflectance has been shown repeatedly to be a good measure of the degree of heating that the sample has undergone (van Gijzel, 1982). Types of kerogen other than vitrinite mature at different rates, and if vitrinite is not present in the sample another type can be used and calibrated to standard Ro data (DGSI, unpubl.). Each Ro data point is determined from a sample which normally has many vitrinite particles present. Twenty or more particles are examined and their individual reflectance values are plotted on a histogram. An ideal histogram would have a normal curve with a small standard deviation. The reported value is the mode (peak) of the distribution. It is not unusual for a bimodal distribution to be found. Recycling of kerogen in sediments is reported to be a common occurrence. In such a case the mode with the higher reflectance would be interpreted to be due to recycled vitrinite, and the mode with the lower reflectance would be due to primary vitrinite (Hunt, 1979). Histograms with very broad and 
diffuse curves may result from reworking of material from more than one source, contamination, or mis-identification of vitrinite.

Histograms for Ro determinations made by DGSI Labs are contained in Appendix D. Histograms for USGS Ro determinations may become available with the publication of additional USGS data.

The determination of the thermal alteration index (TAI), is a visual microscopic technique based on the color of exinite (pollen and spores). Just as vitrinite gets more reflective with increased maturation, exinite will darken in color. Using transmitted light, exinite particles are identified visually and compared to a color chart (DGSI, unpubl.). Both Ro and TAl are reported on numerical scales, and for a given set of samples the results should be correlatable.

It is common practice to perform two or more of the maturation analyses (Ro, TAl, Tmax, PI) on each sample to provide verification of data because significant sources of error or bias exist for each of them. For example reflectance, to be consistent, must be measured on only vitrinite and other organic matter must be ignored, but vitrinite is initially identified partly on the basis of its reflectance (Tissot and Welte, 1984). Thermal alteration index is similarly dependent on the proper identification of spores and pollen. Both techniques are statistical in nature and at low levels of maturity variation can be great (Tissot and Welte, 1984).

Both the position and size of the pyrolysis $S_{2}$ peak can be affected by the level of TOC of the sample, thus affecting both Tmax 
(position of $\left.S_{2}\right)$ and production index $\left(S_{1} / S_{1}+S_{2}\right)$ (Peters, 1986). Low TOC (below about 0.4 to $0.5 w t \%$ ) can reduce the volume of $S_{2}$ production and lower the Tmax temperature (Peters, 1986). Tmax temperatures have also been found to vary for different types of organic matter.

Vitrinite reflectance and TAl results must also be interpreted in terms of the type of organic matter present because different types of organic matter have different potentials for the generation of hydrocarbons. Type of organic matter exerts a primary control over the type of the petroleum products generated (Barker, 1982). Visual kerogen assessment provides a determination of type of organic matter. By microscopic visual identification of constituent particles kerogen is classified according to the types of original organic material. These classes can be correlated to other descriptive systems such as the classification of Espitalie and others (1977) shown in Table 3 . Visual assessment data is summarized in Appendix $C$ in terms of normalized percentages of the three main kerogen constituents: vitrinite, liptinite and inertinite. Complete microscopist reports including descriptive information and minor organic constituents are in Appendix E.

Visual assessment also provides an important check on data quality. If weathering of the kerogen in the sample has occurred, degradation will be visually apparent. Weathering greatly reduces TOC and rock-eval responses (W. Dow, personal communication, 1994). 
TABLE 3: MACERALS, KEROGEN TYPE AND ORGANIC PRECURSORS.

(Waples, 1985)

MACERAL

KEROGEN TYPE

ORIGINAL ORGANIC

MATTER

Alginite

1

Fresh-water algae

Exinite

II

Pollen, spores

Cutinite

II

Land-plant cuticle

Resinite

II

Land-plant resins

Liptinite

II

All land-plant lipids; marine algae

Vitrinite

III

Woody and cellulosic material from land plants

Inertinite

IV

Charcoal; highly oxidized or reworked material of any origin 


\section{GEOLOGY OF THE TYEE BASIN}

\section{STUDY AREA}

Cuttings and outcrop samples analyzed for this study were from the southern Tyee basin in southwest Oregon (fig. 1). The Eocene section in the Tyee basin is a $6100 \mathrm{~m}(20,000 \mathrm{ft})$ thick accumulation of sedimentary rocks. The southern portion of the basin probably has a greater oil and gas potential than the area to the north (Niem and Niem, 1990; Ryu and others, 1992). Adjacent pre-Tertiary units of the Klamath Mountains have not been included in this study although some potential source rocks occur there as well (Niem and Niem, 1990).

\section{PREVIOUS WORK}

The Eocene rocks of the southern Tyee basin were first described by Diller (1898) who also discussed adjacent Jurassic and Cretaceous rock units of the northern Klamath Mountains. Baldwin (1974) mapped and developed the stratigraphy and sedimentology of the basin. His stratigraphic interpretation is 
shown in Figure 7. Other sedimentologic studies have been done by Snavely and others (1964) and Lovell (1969).

More recently, depositional models have been defined by Chan (1982), Heller (1983), Chan and Dott (1983) and redefined by Ryu and others, (1992) and Ryu (personal communication, 1994). Ryberg $(1984,1989)$ also discussed depositional environments and described the plate tectonic and structural setting of the basin. A subduction zone boundary between the Roseburg Formation volcanics (nomenclature of Baldwin (1974)) and the pre-Tertiary Klamath Mountains had previously been suggested by Perttu and Benson (1980). Baldwin (1984) interpreted blueschist and greenstone within the Roseburg Formation as olistostromal slide blocks. These have since been reinterpreted as overthrusts and klippen of pre-Tertiary Klamath terrane rocks over Roseburg Formation rocks (Roure, and others, 1986) or as tectonic melange (Niem and Niem, 1990).

Paleontologic studies have been undertaken by a number of workers including Thoms (1965), Bird (1967), McKeel (1972) and Miles (1977). Ryu (personal communication, 1994) has examined subsurface micropaleontology in an effort to improve surface to subsurface correlation.

Niem and Niem (1990) published a preliminary analysis of the oil and gas potential of the Tyee basin involving compilation of preexisting mapping, a brief study of seismic reflection lines, and 


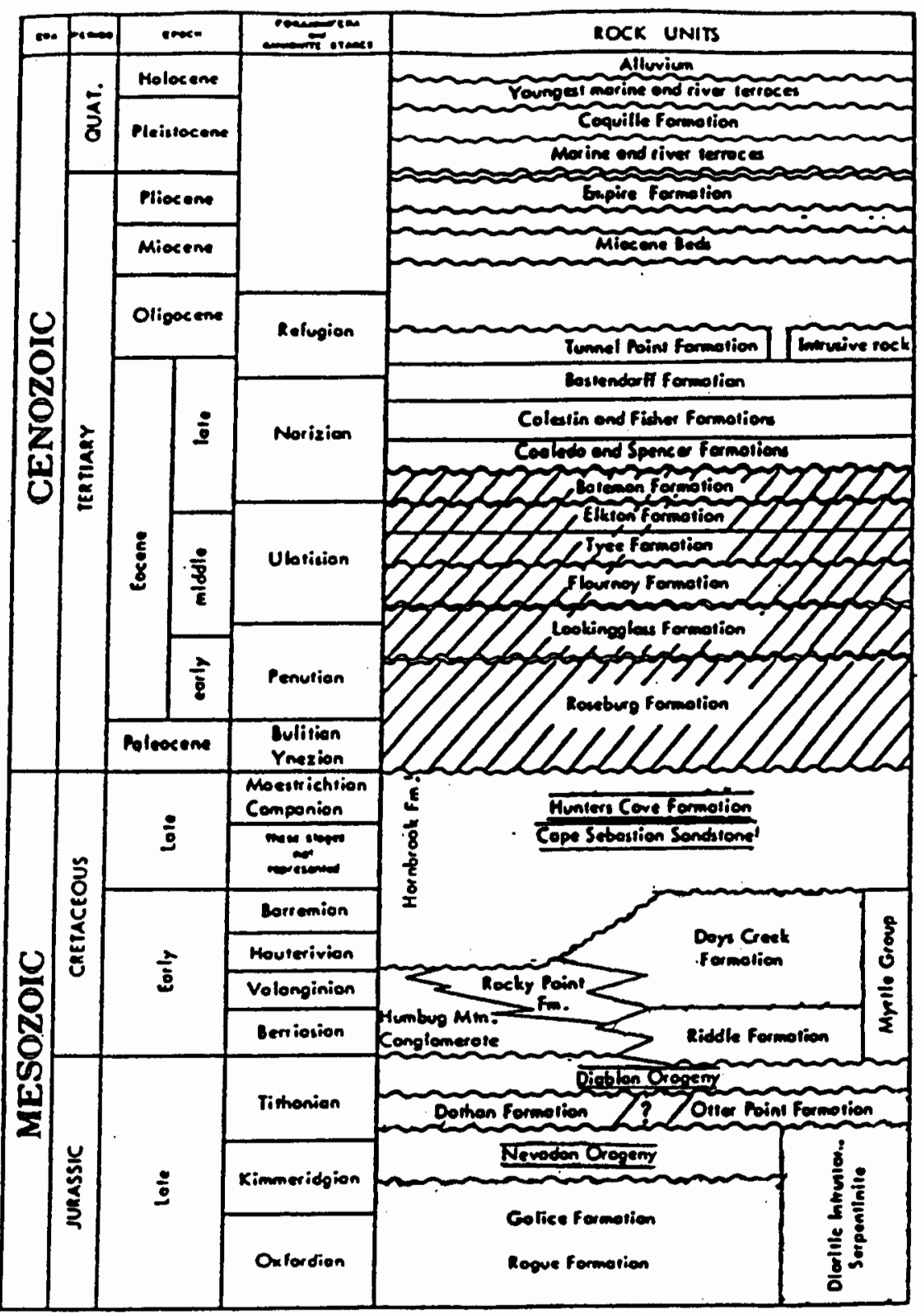

Q7] units in the sucudy area.

Figure 7: Units in the study area (nomenclature of Baldwin, 1974). (Slightly modified from Baldwin, 1974) 
compilation of the limited source rock, maturation, porosity and permeability data from industry and government agencies. Oil and gas shows in exploration wells throughout the basin have led Niem and Niem (1990) to conclude that the petroleum potential of the basin warranted further investigation. As part of that ongoing investigation a fence diagram, correlating stratigraphy revised from Baldwin (1974) and Molenaar (1985) with measured sections and exploration wells in the basin, was produced by Ryu and others (1992).

Prior studies which included organic geochemical data, in most cases very limited, have been done by Browning and Flanagan (1980), Newton (1980), and Law and others (1984). Data from these studies along with data from unpublished reports from Ogle Petroleum Corporation, Amoco Production Company and Mobil Oil Corporation have been compiled in Niem and Niem (1990). Analyses by industry have been concentrated on the Cretaceous Days Creek Formation of the Klamath Mountains and the early Eocene Roseburg Formation of the southern Oregon Coast Range. The younger Eocene Tyee and Flournoy Formations (fig. 7) have been largely ignored, although they contain potentially very abundant coal in the southern part of the basin, where a locus of gas seeps has also been reported (Niem and Niem, 1990). Niem and Niem (1990) have also compiled data from analyses of coals in the basin from Lesher (1914) and other unpublished industry and federal agency sources. 


\section{STRUCTURE AND TECTONIC SETTING}

During the Paleocene and early Eocene subduction of the Farallon and Kula oceanic plates was occurring at the western margin of the North American plate (Atwater, 1970). Coast Range basalts dated between 49 and 62 Ma (Duncan, 1982) coincide with spreading reorganizations of these plates. Several interpretations have been suggested for the origin and emplacement of these mafic volcanics. Duncan (1982) interpreted his age dates, which were youngest near the center of the Coast Range and progressively older to the north and south, as evidence that the tholeiitic basalts were the result of a spreading ridge centered over a hot spot. This ridge then collided with North America as the hot spot was overridden by the North American Plate. Emplacement of the basaltic oceanic crust that forms the basement rocks of the Tyee basin, at the southern end of the Coast Range, is included in this process.

Wells and others (1984), examining the Siletz River volcanics of the Tyee basin (Roseburg basalts of Baldwin, 1974), found too much evidence of continental influence to accept this hypothesis. Citing the presence of Klamath Mountains-derived conglomeratic interbeds and evidence of subaerial flows, they suggested that these basement volcanics were erupted in place during continental margin rifting. 
Many investigators have favored the interpretation that these oceanic basalts are a remnant of the Farallon Plate, accreted onto the North American Plate during a westward jump of the subduction zone of the Farallon Plate beneath the North American plate (fig. 8) (Armentrout and Suek, 1985; Snavely and others, 1980; Perttu and Benson, 1980). It has been proposed that seamounts along the Farallon spreading ridge were partially subducted beneath the North American plate. These seamounts, along with underthrusted slabs of oceanic crust, therefore form the volcanic basement (fig. 9) (Heller and Ryberg, 1983). Ryu and others (1992) have named the deeply buried, northwest-southeast trending Paleocene to early Eocene basin formed by the subsidence of these volcanic rocks the Umpqua basin. The Umpqua arch, a volcanic high which is interpreted to be the remnant of the partially subducted seamounts, separates the basement rocks of the Umpqua basin into two subbasins. These are the Myrtle Point-Sutherlin sub-basin to the south, and the Smith River sub-basin to the north (fig. 10). The Myrtle Point-Sutherlin sub-basin is further divided by the Reston high, a paleotopographic ridge formed by later deformation along the Reston thrust fault.

In each of these interpretations the southern margin of the North American plate in the study area is formed by the Klamath Mountains. The accreted oceanic crust or rift volcanism is represented by the complex, highly deformed pile of trench turbidites (upper part) and volcanic rocks (lower part) of the 

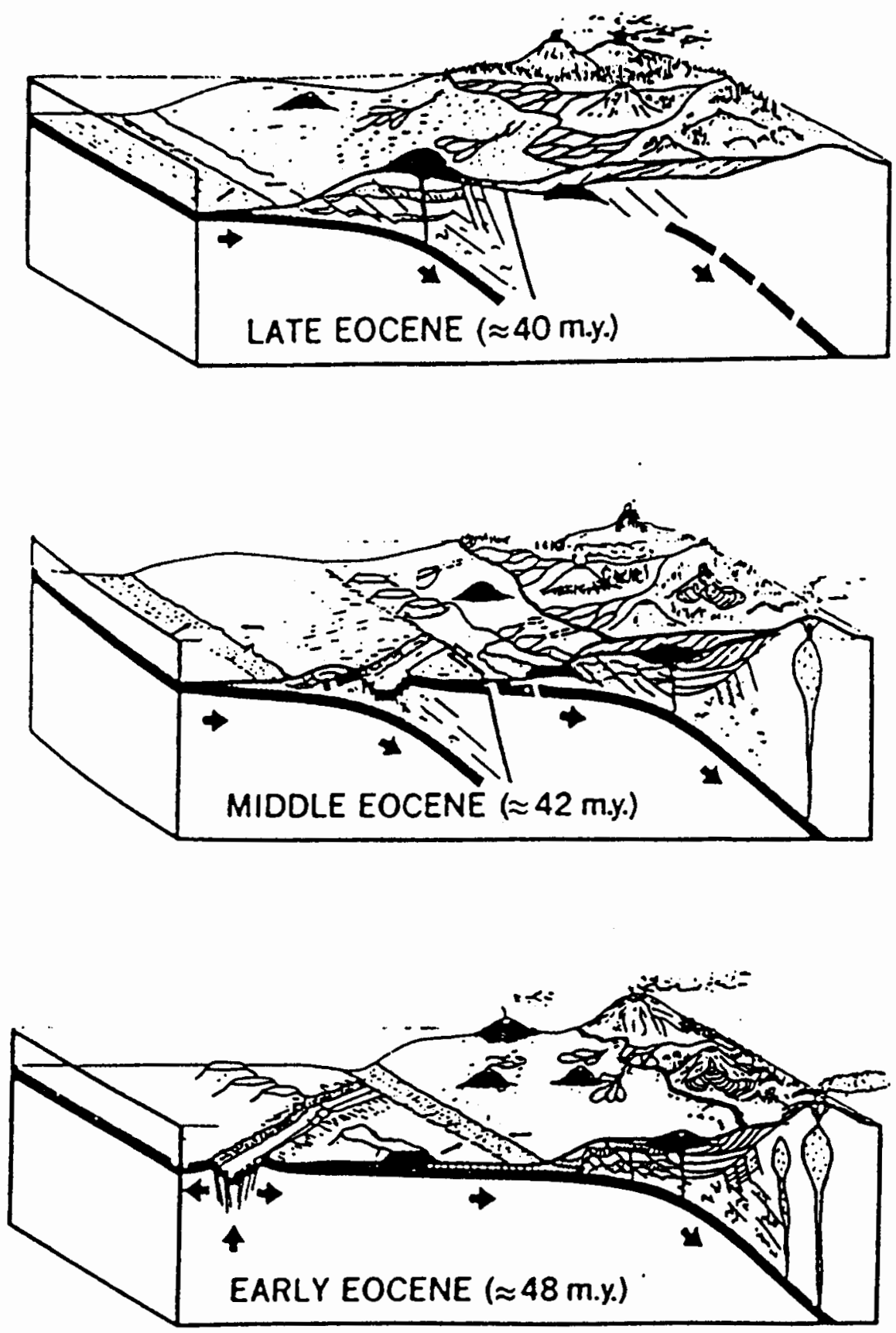

Figure 8: Simplified tectonic model of the Oregon Coast Range. (Armentrout and Suek, 1985) 


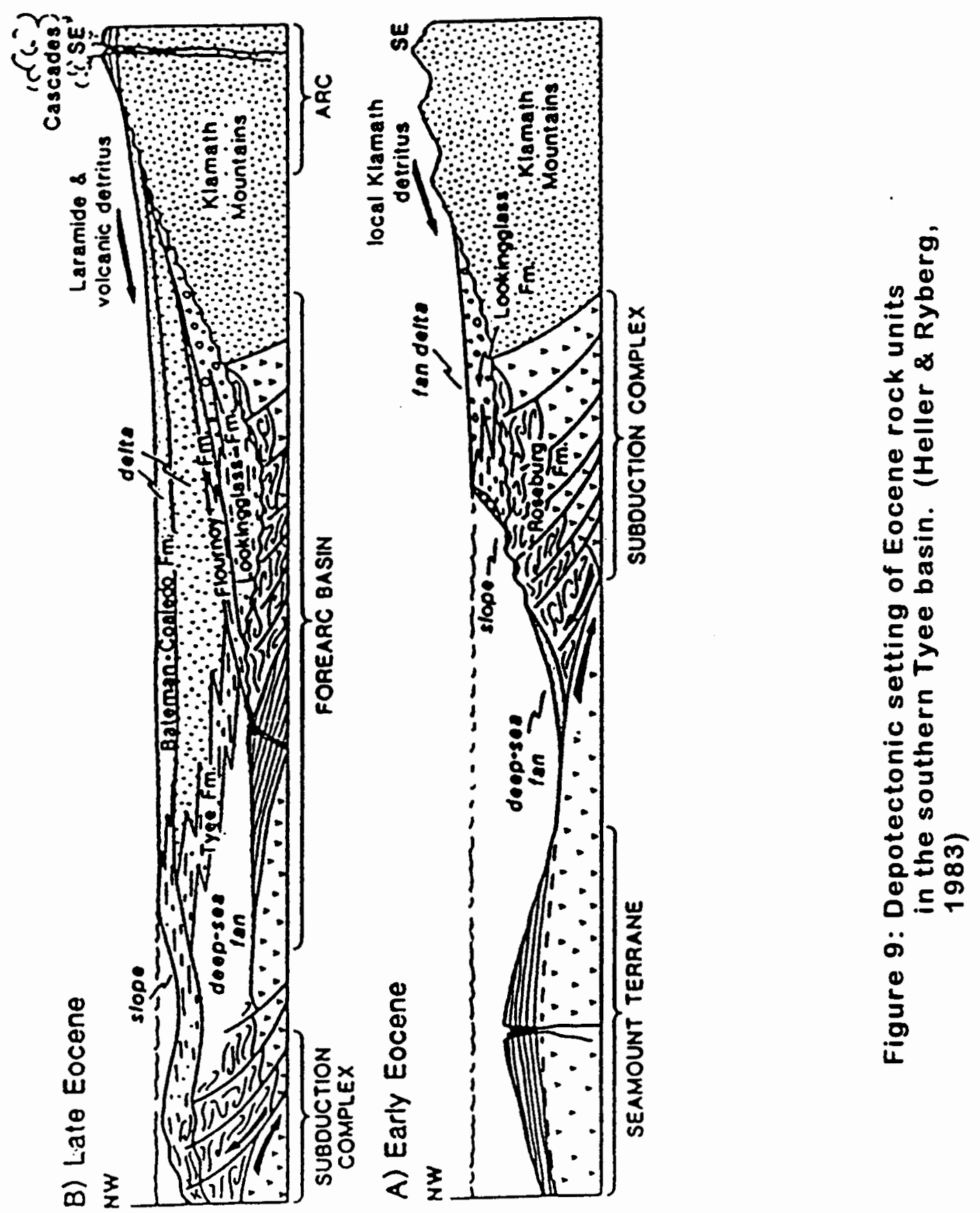




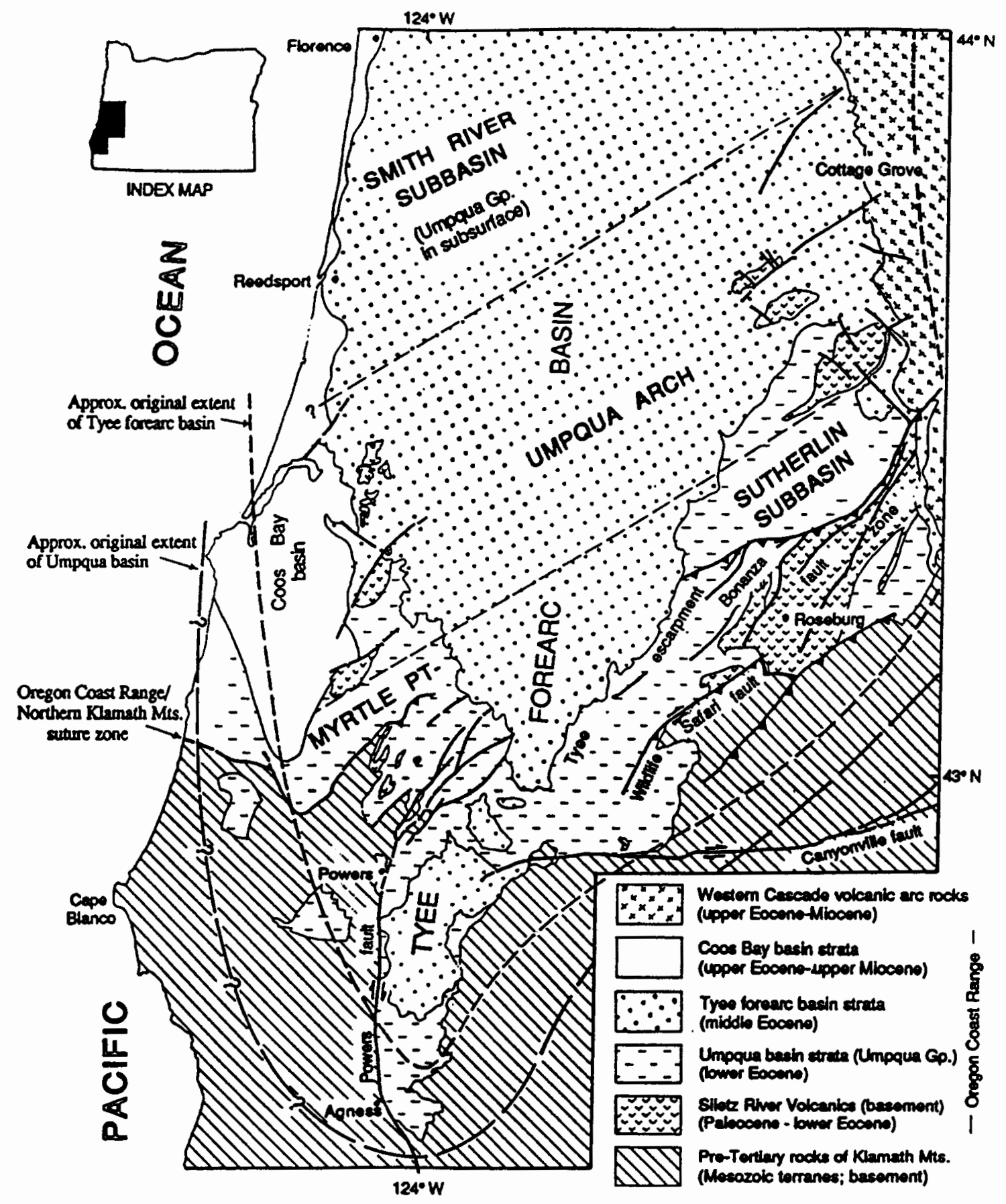

Figure 10: General geology and tectonic features of the southern Tyee basin. (Ryu and others, 1992) 
Roseburg Formation (nomenclature of Baldwin, 1974) (Duncan, 1982; Snavely and others, 1980; Niem and Niem, 1990).

The tectonic relationship of these volcanic rocks to the preTertiary rocks of the Klamath Mountains is an important factor in oil and gas exploration in the Tyee basin (Ryu and others, 1992). The hypotheses described above each imply very different structural relationships among the volcanics, the continental Klamath terranes and the overlying sedimentary rocks. An underthrusting oceanic plate hypothesis implies throughgoing thrust faults and the possibility of Umpqua sediments being subducted to greater depths where organic maturation is more likely to take place. It also implies potential structural traps. Eruption of the mafic volcanics in place in an extensional regime implies either unconformity or strikeslip fault contacts with the Klamath rocks and relatively flat-lying geometries in the mafic volcanics and Eocene sedimentary strata.

Various interpretations of the depositional environments for the units in the basin have strongly influenced interpretations of the tectonic history. The Roseburg Formation sediments and the Lookingglass Formation (Baldwin, 1974) have been interpreted as different parts of the same depositional system in a subduction zone environment (Heller and Ryberg, 1983). Alternatively, the Roseburg Formation may be a trench fill (Baldwin and Perttu, 1989) or submarine fan (Ryberg, 1984) that was deformed by active subduction during deposition. The Lookingglass Formation may be associated fan-delta and upper slope deposits that prograded 
outward over the active subduction zone (fig. 9A) (Ryberg, 1989). Subsequently, during and after accretion of the subduction zone, the thick delta and turbidite sediments of the Flournoy, Tyee, Elkton and Bateman Formations prograded across the newly created forearc basin, burying the seamounts and the partially subducted trench fill of the Roseburg Formation (fig. 9B) (Niem and Niem, 1984). Ryu and others (1992) have described this upper, thick, early to middle Eocene section of predominantly turbidites and deltaic strata as a superimposed basin on the Umpqua basin.

Termed the Tyee forearc basin, it was the tectonically quiet depocenter remaining after accretion was completed and subduction moved farther west in the middle Eocene. The younger and less deformed rocks of the north-south trending sequence of sediments that fill this upper basin overlie both sub-basins of the older Umpqua basin.

\section{STRATIGRAPHY}

The Eocene stratigraphy of the southern Oregon Coast Range was initially studied by Diller (1898). He described the Umpqua Formation and overlying Tyee Formation. Baldwin (1965) recognized unconformities in the Umpqua Formation and separated it into three members. These were later elevated to formation status as the Roseburg, Lookingglass and Flournoy Formations of 
the Umpqua Group (Baldwin, 1974). The Tyee Formation remained the same as described by Diller (1898). Late Eocene strata to the north were described and named the Elkton and Bateman Formations (Baldwin, 1974).

Later workers (Molenaar, 1985; Ryu and others, 1992) revised and refined Baldwin's (1974) stratigraphy. These changes are represented in Figure 11. Molenaar (1985) returned to the use of Diller's broader definition of the Umpqua Formation, dropping the Lookingglass and Flournoy Formations due to confusing mapping and stratigraphic relationships across the basin. He also dropped the Olalla Creek Member of the Lookingglass Formation, including it in the White Tail Ridge Member, and dropped the name Roseburg Formation, following the lead of Thoms (1965) by correlating the basalts with the Siletz River Volcanics. Molenaar mapped as Tyee Formation strata that Baldwin (1974) had assigned to the Flournoy Formation, and interpreted what Baldwin had believed to be unconformable units as having interfingered relationships.

Ryu and others (1992) have reinterpreted the sediment deposition in the basin in terms of sequence stratigraphic criteria, recognizing four unconformity-bounded sequences. This work, together with new mapping (Black, 1990, 1993; A. Niem, personal communication, 1994) has led to further modification of the stratigraphic nomenclature of Molenaar (1985). The Camas Valley, White Tail Ridge, Tenmile and Bushnell Rock Members of Molenaar (1985) have been raised to formation rank within the Umpqua Group 


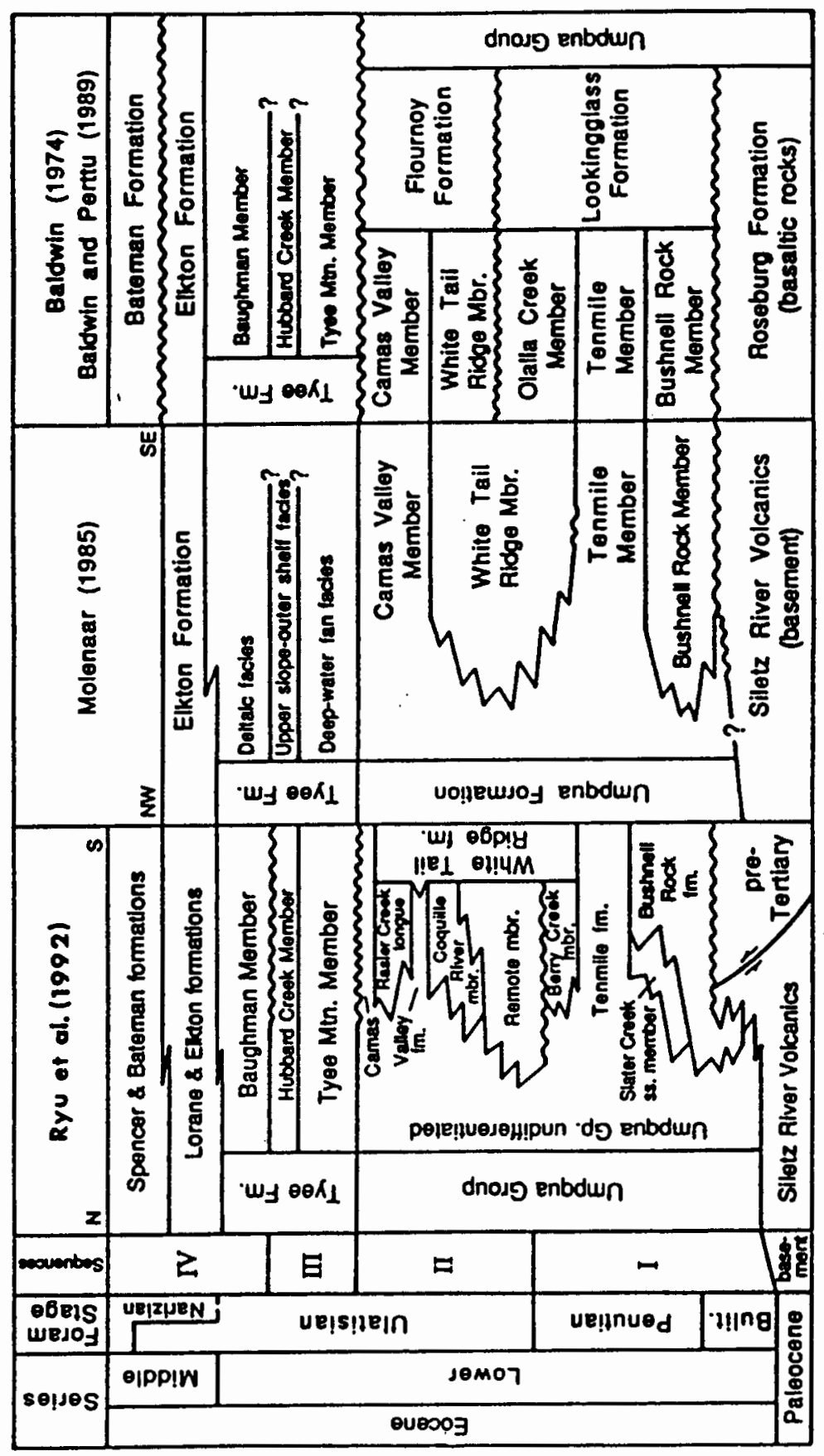

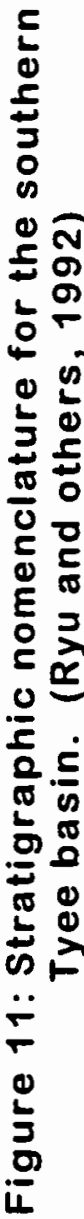


(fig. 11). The Tyee Formation and its three members as named by Baldwin (1974), as well as the Elkton and Bateman Formations, are retained since they can be mapped and correlated throughout the basin (I.-C. Ryu, personal communication, 1994). Molenaar's reinterpretation of the areal extent of the Tyee Formation has been dropped (Ryu and others, 1992). Several new members and tongues have been recognized: the Slater Creek Member of the Bushnell Rock Formation, and the Berry Creek, Remote and Coquille River Members and Rasler Creek Tongue of the White Tail Ridge Formation (fig. 11) (Ryu and others, 1992).

The base of the Cenozoic section in the southern Coast Range is the Roseburg Formation (Baldwin, 1974).* Roseburg Formation basalts in the southern Tyee basin have long been recognized as generally correlative to the Siletz River Volcanics (Thoms, 1965; Baldwin, 1974). Ryu and others (1992) followed Molenaar (1985) who followed Thoms (1965) in using the name Siletz River Volcanics in the southern Tyee basin, although there are some recognized distinctions between these and the type Siletz River Volcanics to the north. The Roseburg/Siletz River Volcanics include pillow basalts, subaerial flows and breccias. Imbricate thrusting and poor exposure make it impossible to determine the thickness of the volcanic section. In the southern Umpqua basin these volcanics

\footnotetext{
*Divergent stratigraphic interpretations of different workers have required references to more than one system of stratigraphic nomenclature throughout this paper. Refer to Figure 11 to avoid confusion.
} 
interfinger with turbidite lithic sandstone and mudstone, as well as polymictic conglomerate derived from the Klamath Mountains (Baldwin, 1974; Ryu and others, 1992). Previously, the conglomerate was termed the Bushnell Rock Member of the Lookingglass Formation and the turbidite sandstones and mudstones were grouped with the volcanics in the Roseburg Formation (Baldwin, 1974). Ryu and others (1992) have used the name Bushnell Rock Formation for the conglomerate and associated coarse-grained lithic sandstone. The turbidite sandstone and mudstone that mainly overlie but also interfinger with the volcanic rocks are termed undifferentiated Umpqua Group. In the central part of the basin the Bushnell Rock Formation pinches out (Ryu and others, 1992). The correlative deep-marine turbidites and mudstones that overlie the Siletz River Volcanics in the northern part of the basin are also included in the undifferentiated Umpqua Group (fig. 11).

The Lookingglass Formation (Baldwin, 1974) unconformably overlies the Roseburg Formation/Siletz River Volcanics and onlaps the pre-Tertiary formations to the south (fig. 9B) (Heller and Ryberg, 1983). Baldwin's Bushnell Rock Member of the Lookingglass Formation has been raised to formation status by Molenaar (1985) and Ryu and others (1992) because there are mappable members within the unit. It locally interfingers with the Siletz River Volcanics near the middle of the basin, then gets thinner, finer and finally pinches out to the north (Ryu and others, 1992). 
The Bushnell Rock Formation is composed of thick-bedded polymictic conglomerates and subordinate, poorly-sorted lithic sandstone. It has previously been interpreted as a fan-delta deposit (Ryberg, 1984; Niem and Niem, 1990), and partially as a submarine canyon or channel deposit (Ryberg, 1984; Molenaar, 1985; Niem and Niem, 1990). Ryu and others (1992) have identified four lithofacies within the Bushnell Rock Formation. These are a fanglomerate and fan-delta facies, a deep-marine conglomerate and sandstone, a thick-bedded fine-grained sandstone (Slater Creek Member), and a coarse-grained shallow-marine and beach sandstone.

The fanglomerate facies occurs in the south-central part of the basin and is as much as $730 \mathrm{~m}(2400 \mathrm{ft})$ thick. Where it is thickest, it unconformably overlies pre-Tertiary Klamath Mountain terrane rocks, which are in turn thrust over Siletz River Volcanic pillow lavas. The fanglomerate thins rapidly to the northeast and northwest. A subordinate fan-delta facies interfingers with the upper part of the fanglomerate. Ryu and others (1992) propose a depositional model of coalescing alluvial fans prograding into the sea as fan deltas. The deep-marine conglomerate and sandstone facies is thickest in the southeastern part of the basin, where it is as much as $300 \mathrm{~m}(1000 \mathrm{ft})$ thick. It is interpreted to be a separate submarine canyon or upper submarine valley fill, deposited as sea level rose across the fanglomerate fan-delta shoreline.

The fan-delta facies is overlain by, and interfingers with, the sandstone Slater Creek Member in the south-central part of the 
basin. The Slater Creek Member is tentatively identified as a shallow marine deposit. It thins very rapidly to the east, and its relationships to the Bushnell Rock and Tenmile Formations on its eastern margin are unclear. In the Great Discovery 2 well it is over $450 \mathrm{~m}(1500 \mathrm{ft}$ ) thick, but just over six km (four $\mathrm{mi}$ ) away to the southeast it cannot be found in outcrop (Ryu and others, 1992). To the west both the Slater Creek Member and the fanglomerate facies thin rapidly to shallow-marine coarse-grained lithic sandstone and pebble conglomerate interpreted as beach and shallow shelf deposits of the Bushnell Rock Formation. These unconformably overlie pre-Tertiary Klamath Mountain terrane rocks. Contact and thrust fault relations indicate that the Bushnell Rock units were deposited contemporaneously with tectonic activity on the continental margin, prograding northward from the uplifted Klamath Mountains (Heller and Ryberg, 1983; Ryu and others, 1992).

The Tenmile Formation (Tenmile Member of Baldwin (1974) and of Molenaar (1985)) (fig. 11) conformably overlies the Bushnell Rock Formation in the southern and southeastern parts of the basin. The Tenmile Formation consists of as much as $900 \mathrm{~m}(3000 \mathrm{ft})$ of thick sequences of alternating thin-bedded turbidites and marine mudstone. These are interpreted as deep-marine deposits, although there is some evidence of shallowing in the southern part of the basin in the uppermost part of the formation (Ryu and others, 1992). Where the Bushnell Rock and White Tail Ridge Formations pinch out farther north, the Tenmile Formation becomes 
indistinguishable from the rocks of the undifferentiated Umpqua Group (fig. 11). Ryberg (1984) tentatively mapped some of the upper part of the Tenmile Formation in the Agness-Powers area (fig. 10) to be fluvial and alluvial fan deposits based on conglomeratic beds similar to the Bushnell Rock Formation in lithology. Ryu and others (1992) include these rocks in the Tenmile Formation, but interpret them as deep-marine channel fill deposits. In the southern part of the basin the Tenmile Formation overlies an unconformity on older Umpqua Group and Siletz River Volcanics, but to the north it interfingers with younger turbidites and mudstone of the undifferentiated Umpqua Group. These relationships indicate that the Tenmile Formation was at least in part deposited contemporaneously with tectonic activity (Heller and Ryberg, 1983; Ryu and others, 1992).

The White Tail Ridge Formation as redefined by Molenaar (1985) and Ryu and others (1992) is the combination of Baldwin's Olalla Creek Member of the Lookingglass Formation and White Tail Ridge Member of the Flournoy Formation. Ryu and others (1992) agree with Molenaar (1985) that the unconformity that Baldwin mapped between the two members is not regional, and may in fact result from deformation due to proximity to local faulting instead. The White Tail Ridge Formation has a maximum thickness of $1070 \mathrm{~m}$ $(3500 \mathrm{ft})$ in the southeastern part of the basin where it infilled paleotopographic lows formed by local penecontemporaneous faulting (Ryu and others, 1992). In the southernmost part of the 
basin the White Tail Ridge Formation consists of an undifferentiated, homogeneous fluvial-deltaic facies.

Farther north four members can be distinguished and mapped (Ryu and others, 1992). These are the Berry Creek Member, Remote Member, Coquille River Member and Rasler Creek Tongue (fig. 11). The Berry Creek Member, a shallow-marine bioturbated sandstone, conformably overlies and may interfinger with the uppermost part of the Tenmile Formation. The Berry Creek Member has been locally erosionally truncated by the overlying Remote Member. The Remote Member, a non-marine fluvial and distributary channel conglomerate, has incised into the Berry Creek Member and in some places rests directly on the Tenmile Formation (Ryu and others, 1992). The Remote Member interfingers with, and grades into, the overlying Coquille River Member (Ryu and others, 1992). The Coquille River Member, a wave-dominated delta front facies that consists of shoaling upward sequences of lithic arkosic sandstone, interfingers with the Camas Valley mudstones and the Rasler Creek Tongue. The Rasler Creek Tongue, within the Camas Valley Formation and undifferentiated White Tail Ridge Formation, is made up of several thickening-upward sequences of wave-dominated delta front and delta coastal plain sandstone. Toward the north the tongue grades into the Camas Valley Formation mudstones, which also overlie and underlie it (fig. 11) (Ryu and others, 1992). All of these sandstone units thin and fine northward, grading into the outer shelf and slope mudstones of the undifferentiated Umpqua 
Group (Ryu and others, 1992). These interpretations are more detailed but in general agreement with facies patterns established by previous workers (Lovell, 1969; Molenaar, 1985).

The Camas Valley Formation, a massive mudstone, is the topmost unit of the Umpqua Group. In the southern part of the basin the Camas Valley formation is separated into lower and upper parts by the Rasler Creek Tongue of the White Tail Ridge Formatian. The lower part rests on and interfingers with the Coquille River Member of the White Tail Ridge Formation (fig. 11). Ryu and others (1992) agree with Molenaar (1985) that the Camas Valley Formation is an outer shelf or upper slope deposit. Farther north, where the Coquille River Member and Rasler Creek Tongue pinch out, the Camas Valley Formation is indistinguishable from the mudstones of the undifferentiated Umpqua Group (Ryu and others, 1992; Molenaar, 1985).

The middle Eocene Tyee Formation overlies the Umpqua Group. It is the most widespread formation in the study area and is estimated to have a maximum thickness of 1500 to $2040 \mathrm{~m} \mathrm{(5000} \mathrm{to}$ $6700 \mathrm{ft}$ ). It is disconformable over the Umpqua Group in the south, but in the central and northern portions of the basin may be conformable (Ryu and others, 1992). It was divided into the Tyee Mountain Member, Hubbard Creek Member, and Baughman Member by Baldwin (1974). Later workers (Molenaar, 1985; Ryu and others, 1992; A. Niem, personal communication, 1994) have continued to use this nomenclature (fig. 11), but due to more detailed mapping 
than had previously been attempted in some areas, have greatly expanded the mapped areal extent of the members of the Tyee Formation (fig. 12). Furthermore, Ryu and others (1992) concluded that some Tyee Formation micaceous turbidite strata in the northern part of the basin had been incorrectly mapped as Flournoy Formation, confusing depositional interpretations (Heller and Dickinson, 1985; Chan and Dott, 1983).

Depositional models for the Tyee Formation had been proposed based on limited mapping and scattered and incomplete measured sections. Chan and Dott (1983) proposed a delta, slope and sandy submarine fan system, and Heller and Dickinson (1985) proposed an interfingering delta and inner and outer ramp environment. They interpreted the vertically stacked members as chronostratigraphic facies, that is, time equivalent units representing the lateral migration of environments and progradation of the deposition of one unit over another, applying Walther's Law (Davis, 1983). But Ryu and others (1992) and Ryu and Niem (1993) have recognized local unconformities, or sequence boundaries, at the base of the Baughman Member, suggesting that the units represent separate depositional events based upon sequence stratigraphic analysis.

The lowermost Tyee Mountain Member is a thick sequence of micaceous, lithic, arkosic turbidite sandstones and mudstones. It is an upward-thickening sequence indicating progradation of a middle fan facies over an outer submarine fan or ramp. The overlying 


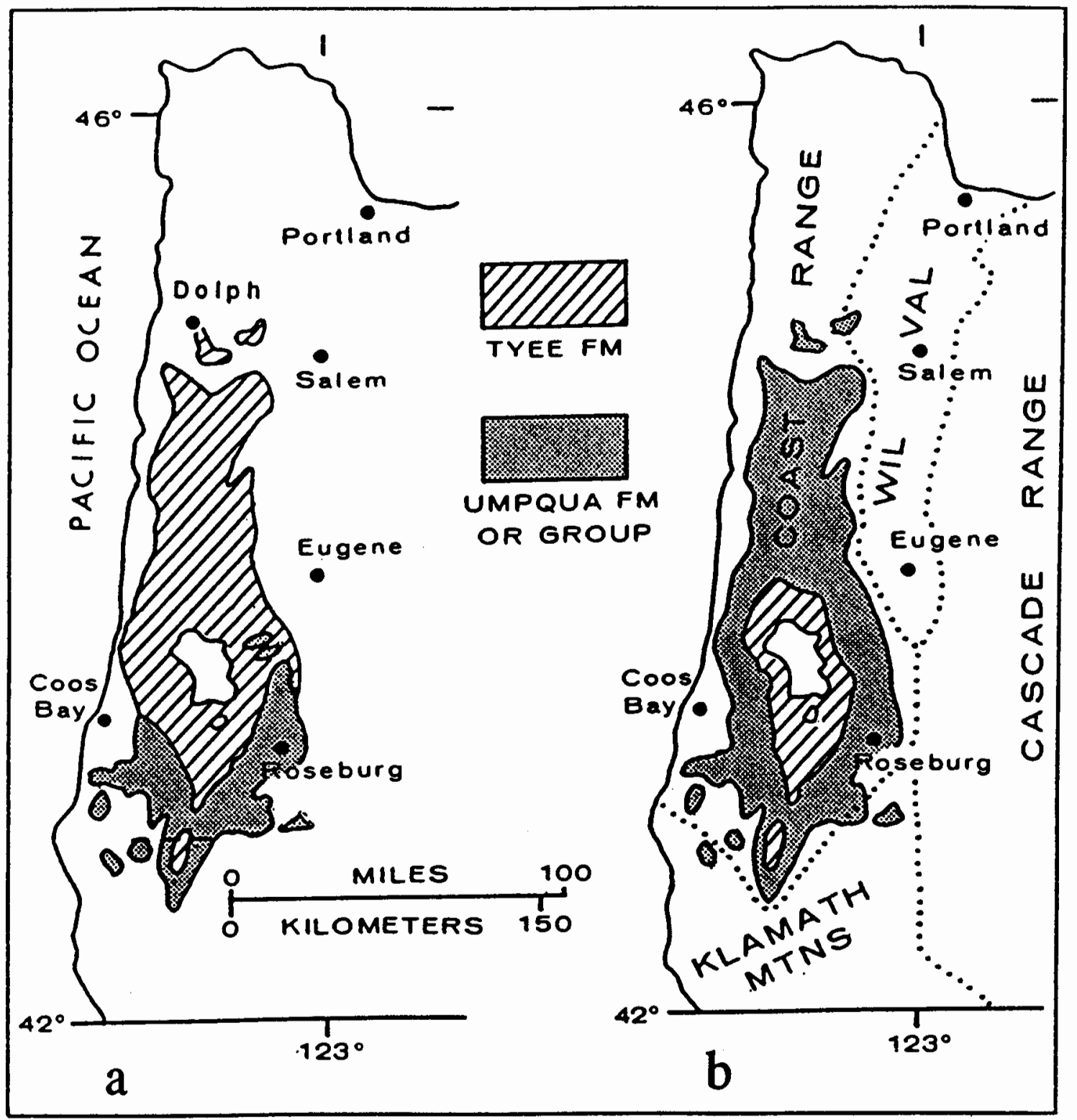

Figure 12: Distribution of Tyee Formation and the Umpqua Group:

a) interpretation of Molenaar (1985),

b) interpretation of Baldwin (1974). (Molenaar, 1985) 
Hubbard Creek Member consists of three units: a massive mudstone, a local channelized turbidite sandstone and an upper massive, bioturbated mudstone. They are interpreted as lower slope, channel, and outer shelf to upper slope deposits respectively (Ryu and others, 1992). The unconformably overlying Baughman Member is predominantly a clean, coarse-grained, cross-bedded, micaceous, lithic arkosic sandstone. It consists of a deltaic facies and a fluvial facies. The fluvial facies contains local pebble conglomerate-filled channels and is restricted to the southernmost part of the basin (Agness to Powers area) (fig. 10). It interfingers with the deltaic facies. The local unconformity at its base is a sharp, irregular, erosional contact. Ryu and others (1992) estimate that up to $150 \mathrm{~m}(500 \mathrm{ft})$ of the Hubbard Creek Member has been eroded in some places. The units are conformable in the northern, deeper part of the basin where deltaic facies of the Baughman Member overlie Hubbard Creek mudstone, defining a sequence boundary.

Four other units occur in the basin but are of lesser significance for this source rock study. They occur high in the section and are either of very limited extent in the study area or are erosionally cut out. They are the Elkton Formation, the Lorane Shale, and the Spencer and Bateman Formations. The Elkton Formation consists of deep-marine mudstone and two intervals of shallow-marine laminated or locally hummocky-bedded turbidite sandstone. It interfingers with the underlying Baughman Member of 
the Tyee Formation, and the contact is gradational. It is preserved only in the center of the Tyee basin (Niem and Niem, 1990). The Lorane Shale, which primarily occurs to the north (Bird, 1967), can be found in the northeast corner of the study area (Niem and Niem, 1990). It is a deep-marine mudstone that has been correlated to the Elkton Formation (Bird, 1967). The Bateman Formation occurs near the center of the basin as a small erosional remnant of a wavedominated delta and shoreface sequence (Weatherby, 1991). It predominantly consists of delta front, distributary mouth bar and distributary channel facies and has a gradational contact with the underlying Elkton Formation. The middle to late Eocene Spencer Formation is a fluvial to deltaic sandstone which occurs primarily north of the study area, resting unconformably over the Lorane Shale. It is probably laterally equivalent to the Bateman Formation (Ryu and others, 1992).

\section{SEQUENCE STRATIGRAPHY}

Sequence stratigraphy is a useful tool for oil and gas exploration because of its genetic approach (Van Wagoner and others, 1990). By relating the sequences of sedimentary strata to the processes that formed them, it makes possible prediction of subsurface geometries and facies changes. In general, changes in sedimentation are related to tectonic or eustatic changes in relative 
sea level at the time and location of deposition. As relative sea level varies through time, predictable changes in depositional environments occur (Van Wagoner and others, 1990).

A hierarchy of terms for stratigraphic units is defined in sequence stratigraphic terminology. A parasequence is a relatively conformable succession of genetically related beds or bedsets bounded by marine flooding surfaces and their correlative surfaces (Van Wagoner and others, 1990). Parasequence sets are genetically related parasequences forming a distinctive stacking pattern and bounded by major marine flooding surfaces and their correlative surfaces (Van Wagoner and others, 1990). Parasequence and parasequence set boundaries form in response to an increase in water depth.

Parasequences and parasequence sets are the building blocks of sequences. A sequence is a relatively conformable succession of genetically related strata that is bounded at its top and base by unconformities and their correlative conformities. Sequence boundaries form in response to relative falls in sea level (Van Wagoner and others, 1990). The exposure of the shelf during a lowstand produces the unconformable surface, while deep in the basin relatively conformable strata are still being deposited.

Landward transgression of the sea initiates the deposition of the next sequence on top of the unconformity surface.

Application of the sequence stratigraphic model relies on the recognition of the systems tract: the linkage of contemporaneous 


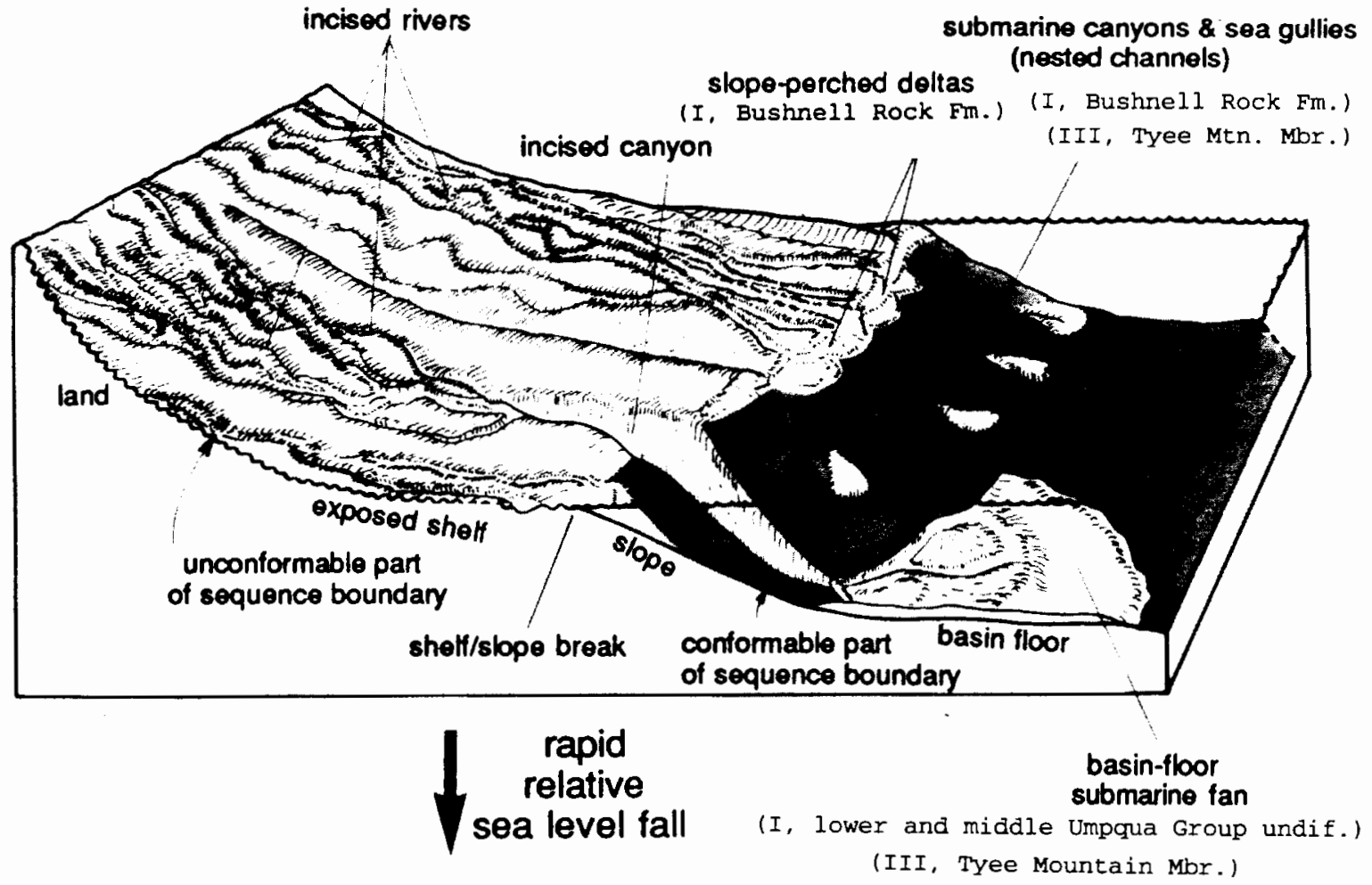

Figure 13: Lowstand systems tract: fan deposition. (Ryu and others, 1992, modified from Van Wagoner, 1990)

depositional systems (Brown and Fisher, 1977). When relative sea level falls, the continental shelf will become exposed. Rivers will at first incise into the shelf, deltas may perch at the shelf/slope break, and deposition will take place deep in the basin via submarine fans. This is a lowstand systems tract (LST) (fig. 13). As sea level 


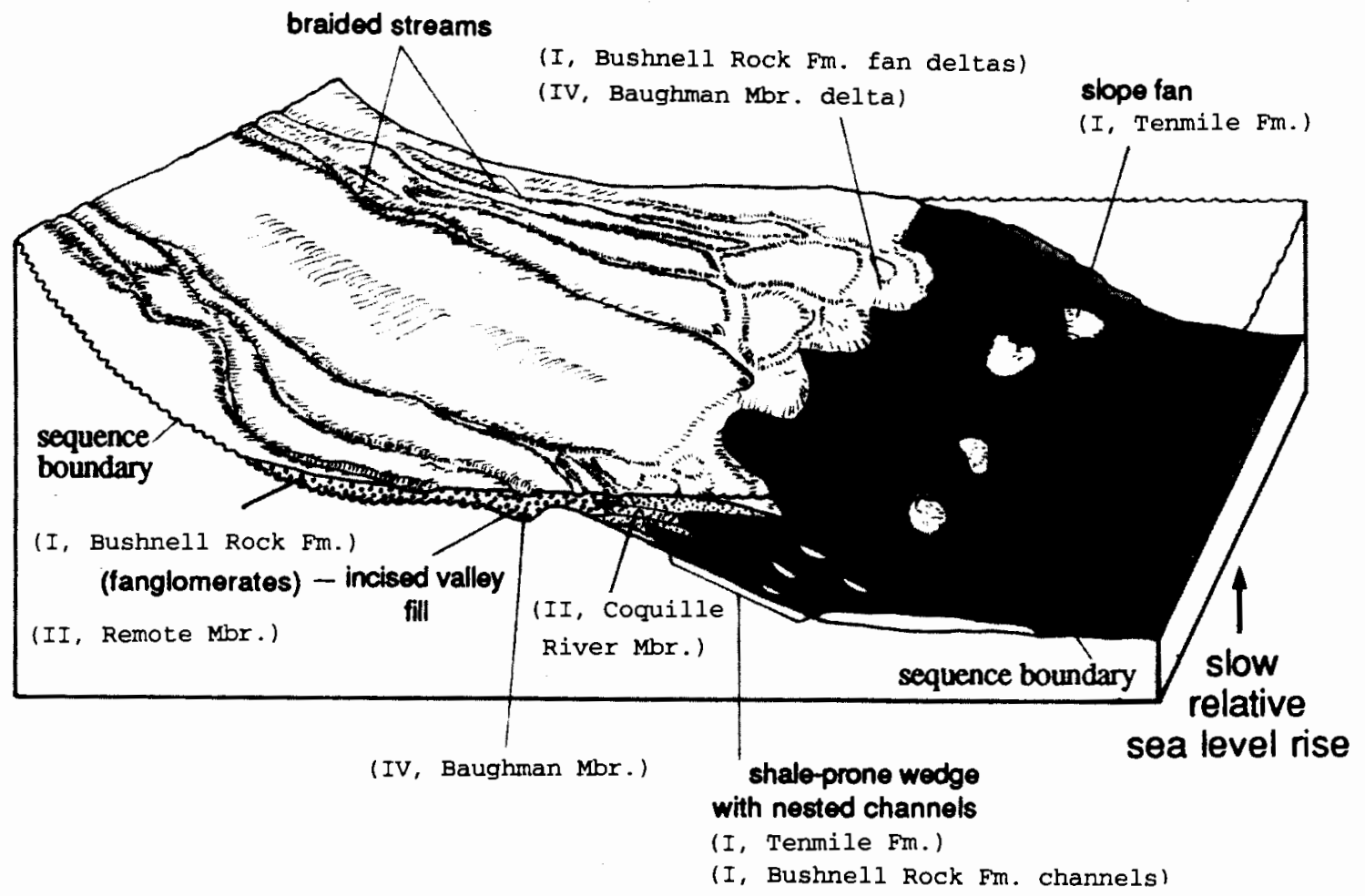

Figure 14: Lowstand systems tract: wedge deposition. (Ryu and others, 1992, modified from Van Wagoner, 1990)

stabilizes, in the second phase of the LST, stream incision is completed and estuaries can form, receiving mixed sands and muds, and depositing a wedge of muds and less abundant turbidite sands that downlap onto the submarine fan (fig. 14). When relative sea level is rising again the transgressive systems tract (TST) produces 


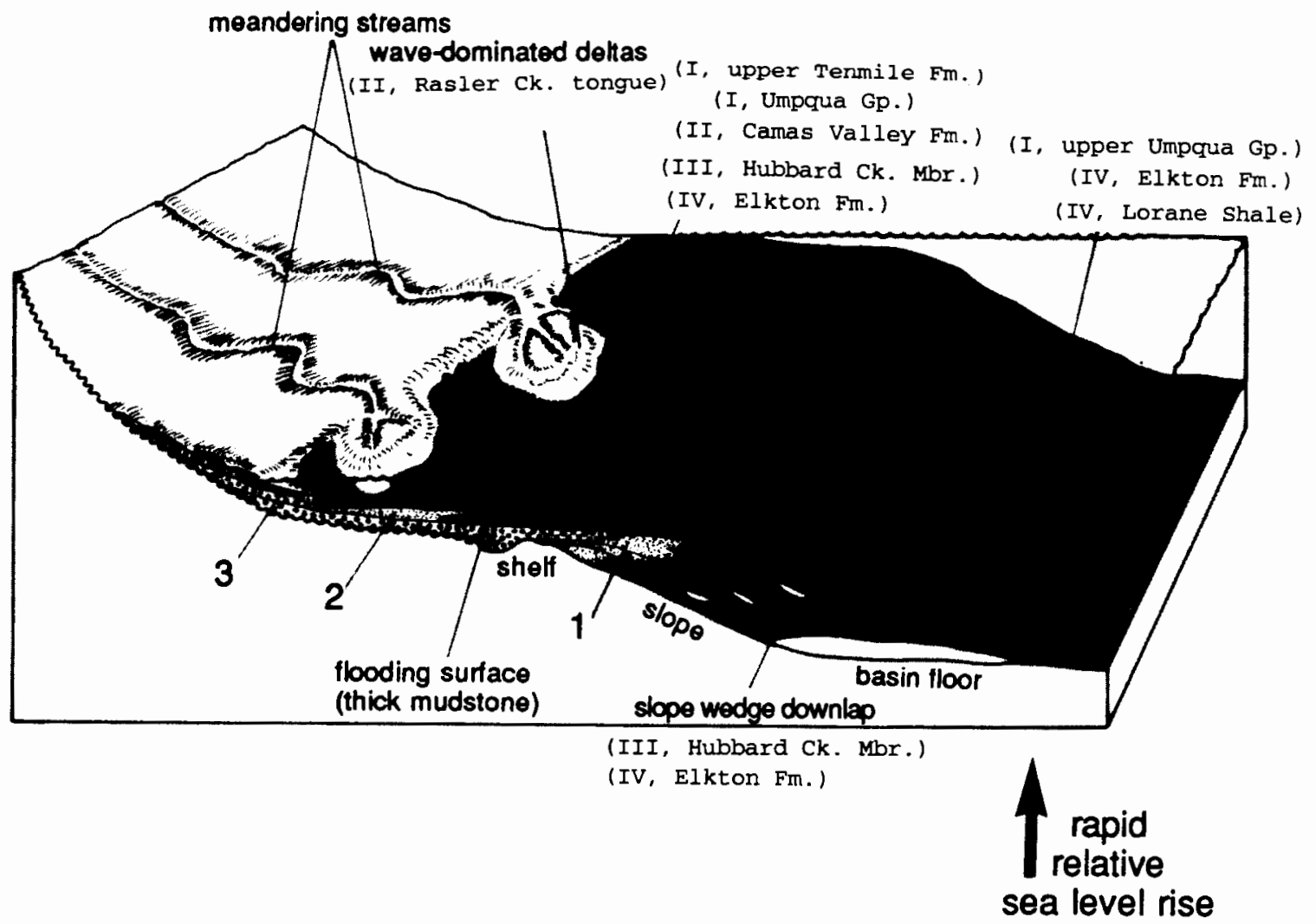

Figure 15: Transgressive systems tract. (Ryu and others, 1992, modified from Van Wagoner, 1990)

retrogradational sets of parasequences as depositional

environments move shoreward. Incised valleys may be backfilled and braided streams deposit sands as the valleys are filled further (fig. 15). When relative sea level is high, streams deposit sands on the continental shelf, deltas prograde toward the basin, and muds 


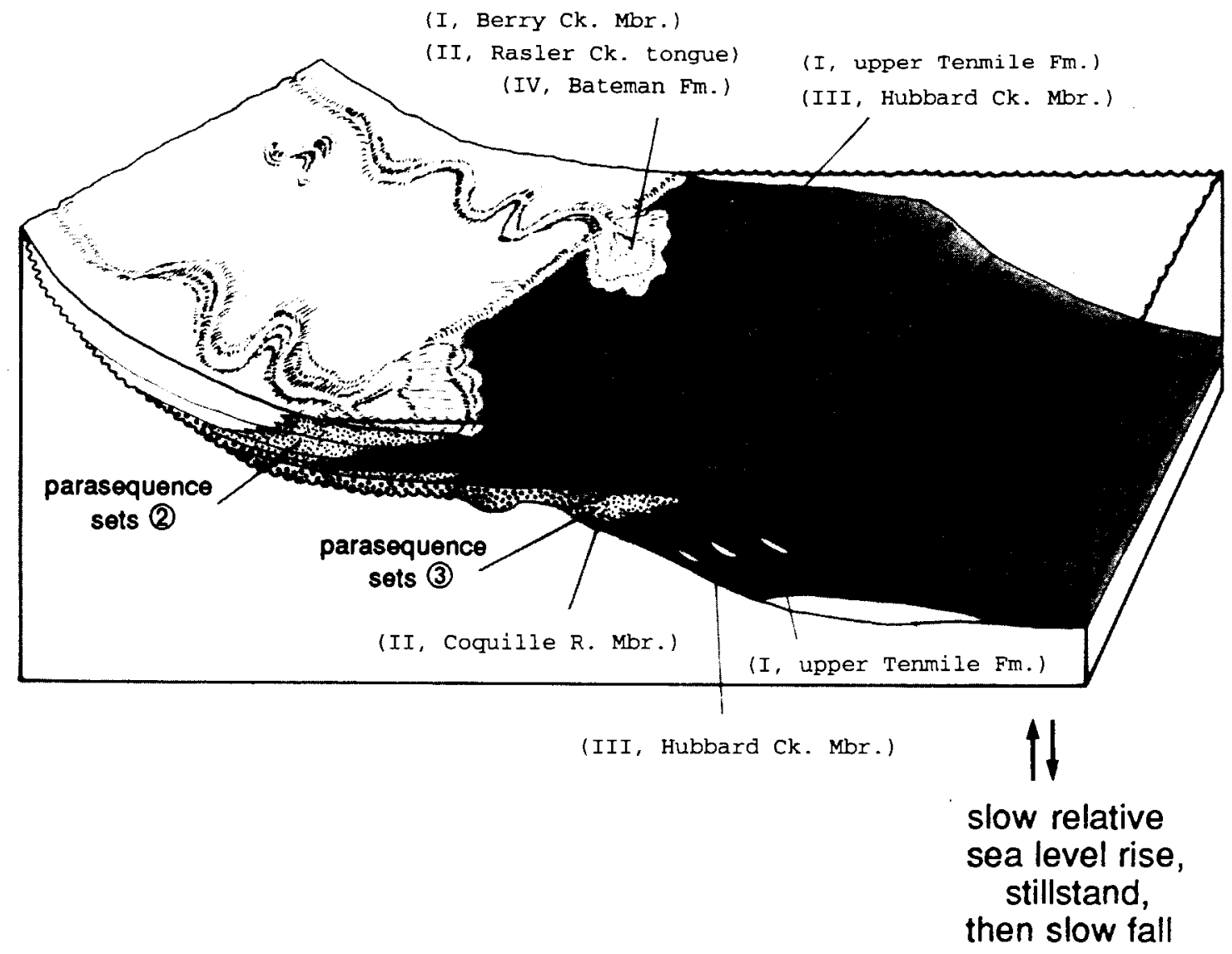

Figure 16: Highstand systems tract. (Ryu and others, 1992, modified from Van Wagoner, 1990)

are deposited farther out on the shelf and downlap into the basin.

This type of environment is called a highstand systems tract (HST) (fig. 16).

It is important to realize the effect that correlation by depositional sequences has on basin analysis. Lithostratigraphic 
units (formations, members) are time transgressive; deposition of a given unit occurs over a period of time that can only be correlated with other units by independent means, such as biostratigraphy. The sequence boundary, on the other hand, like parasequence and parasequence set boundaries, has chronostratigraphic significance; each is a surface that closely approximates a time marker and can therefore be correlated throughout its extent (Wilson, 1975; Anderson and others, 1984; Van Wagoner and others, 1990). The resulting differences in subsurface interpretation can be dramatic (fig. 17), resulting in equally dramatic effects on exploration strategies (Posamentier and Vail, 1988; Posamentier and others, 1988; Van Wagoner and others, 1990).

Sequence stratigraphic concepts were originally developed from studies of cratonic sediments and applied to passive continental margins (Sloss, 1988). Their application to active margins requires the integration of the structural and tectonic history of the region. Tectonic forces will interact with eustatic sea level changes, influencing sedimentation patterns and in some cases resulting in variations from the predicted depositional sequences defined for passive continental margins (Sloss, 1963; Vail and others, 1977; Weimer, 1984; Van Wagoner and others, 1988). In the southern Tyee basin synaepositional tectonism has interrupted the formation of ideal sequences (Ryu and others, 1992). 


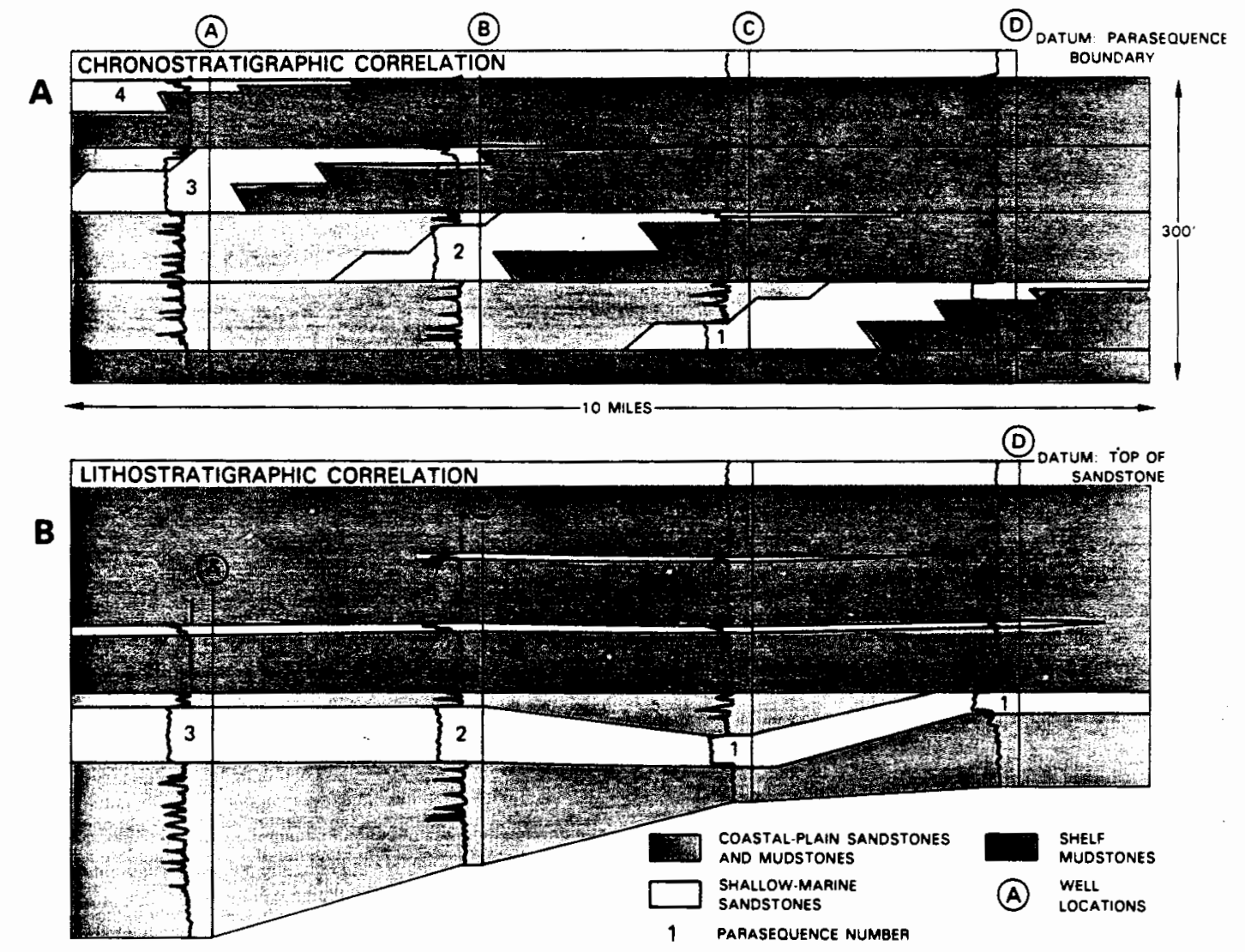

Figure 17: Comparison of A) chronostratigraphic correlation to B) lithostratigraphic correlation: retrogradational parasequence set. (Van Wagoner, 1990)

Ryu (personal communication, 1994) and Ryu and Niem (1993) have applied the sequence stratigraphic model to the Tyee basin with some modifications. They have defined four unconformitybounded sequences (fig. 11). The first sequence (I) began with tectonism and uplift of the northern Klamath Mountains. Streams downcut into the Klamath Mountain terranes and submarine 
channels were cut into the Siletz River Volcanics by turbidite flows

(fig. 13). As sea level began to rise slowly, fanglomerate, fan delta, canyon and inner fan facies of the Bushnell Rock Formation backfilled the canyons that had been eroded (fig. 14). These fans probably fed outer fan turbidites of the undifferentiated Umpqua Group to the north. Much of the overlying Tenmile Formation represents a lowstand wedge with small slope fans (fig. 14). Its deep-marine lithic turbidite strata, trapped in local sub-basins by the Umpqua Arch of Siletz River Volcanic seamounts and oceanic islands, were deposited during a slow transgression as relative sea level rose along the northern Klamath Mountains source terrain. As relative sea level rose more rapidly the upper part of the Tenmile Formation was deposited as a transgressive, outer shelf to upper slope mudstone (fig. 15). At the same time a thin condensed section of deep-marine mudstone accumulated over the Umpqua Arch. The sequence is topped by the sandstone Berry Creek Member of the White Tail Ridge Formation, a highstand progradational delta front deposit, which may be laterally equivalent to the bioturbated mudstones of the upper Tenmile Formation (fig. 16) (Ryu and others, 1992).

The second depositional sequence (II) begins with the Remote Member of the White Tail Ridge Formation. An angular unconformity at its base and the composition and large size of boulders and cobbles near Slater Creek indicate both deformation and local uplift of the Klamath Mountains. The Remote Member has filled steep, 
incised valleys cut into, and sometimes through, the underlying Berry Creek Member and into the upper part of the Tenmile Formation (figs. 13 and 14). To the north and west the Remote Member grades, both laterally and upward, into the delta front and delta plain deposits of the Coquille River Member. Rapid transgression then deposited the deep-marine Camas Valley Formation (fig. 15). It was deposited uniformly over the Reston High of the Myrtle Point-Sutherlin sub-basin (Ryu and others, 1992). The Rasler Creek Tongue, which extends into the Camas Valley Formation, is a highstand progradational delta front deposit (fig. 16). The thin interval of Camas Valley upper slope mudstone that overlies the Rasler Creek Tongue is a transgressive deposit (fig. 15). A mudstone overlying a sandstone does not conform to the sequence stratigraphic model, which predicts that the highstand systems tract, probably truncated by the overlying sequence boundary, will form the top of the sequence (Van Wagoner and others, 1990). Ryu and others (1992) have introduced the term tectonism-forced transgression to describe this case. A tectonismforced transgression occurs when tectonic activity changes the geometry of a basin, leading to a basin-wide rise in relative sea level.

The third sequence (III) includes only the Tyee Mountain and Hubbard Creek members of the Tyee Formation. In the northern part of the basin the Tyee Mountain Member is a very thick basinfloor fan conformable over the Camas Valley Formation. To the 
south, however, it consists of a thin sequence of turbidite sandstone beds filling local feeder channels eroded into the Camas Valley mudstone during a sea level lowstand (fig. 13). The overlying Hubbard Creek Member consists of three units: a massive, lower slope mudstone, a channelized, turbidite sandstone and an outer shelf to upper slope mudstone. The sequence may represent facies from lowstand, transgressive and highstand systems tracts. It may reflect rapid sea level rise and progradation of a highstand deltaic facies that fed the Tyee Mountain Member lowstand fan.

Subsequently the delta was largely eroded away by the late middle Miocene uplift of the southern Oregon Coast Range and northern Klamath Mountains (Ryu and others, 1992).

The fourth sequence (IV) consists of the Baughman Member of the Tyee Formation and the Lorane, Elkton, Bateman and Spencer Formations (Ryu and others, 1992). The Baughman Member consists of a northern deltaic facies that prograded northward and a southern fluvial facies formed by cutting and then backfilling channels eroded into the Hubbard Creek Member (figs. 13 and 14). It is interpreted as indicating a rapid fall, lowstand, then gradual rise of sea level. Eventually the deltaic facies of the Baughman Member, in the central part of the Tyee basin, was covered by transgressive deep marine slope mudstones of the Elkton Formation (fig. 15). The Bateman Formation prograded over the Elkton Formation with a highstand systems tract of deltaic, distributary 
channel and overbank deposits (fig. 16) (Weatherby, 1991; Ryu and others, 1992).

The Bateman Formation represents the final stage of infilling of the Tyee basin in the middle to late Eocene that is preserved today. Subsequent to Bateman Formation deposition a possible plate reorganization in the latest Eocene (Snavely, 1984;

Armentrout, 1987) resulted in renewed rapid oblique subduction, creating the Coos Bay basin (late Eocene to late Miocene strata) on the western edge of the Tyee basin and creating a regional sequence boundary (Ryu and others, 1992). Major late Eocene to late Miocene eruptions of the Western Cascade calcalkaline arc eventually blocked fluvial input of micaceous arkosic sand from the continent (Buckovic, 1979; Armentrout and Franz, 1983).

Subsequent uplift and stream erosion of the southern Oregon Coast Range and northern Klamath Mountains have deeply dissected the middle to upper Eocene Tyee forearc basin sequence. These processes have also re-exposed the underlying, more highly deformed, Umpqua Group subduction complex in the Myrtle PointSutherlin sub-basin and the Siletz River Volcanics basement on the flanks of the forearc basin (fig. 10) (Ryu and others, 1992). 


\section{OIL AND GAS POTENTIAL OF THE TYEE BASIN}

\section{RESERVOIR ROCKS}

Porosity and Permeability

Published porosity and permeability data on potential Eocene reservoir rocks in the Tyee basin (Table 4 ) are limited to a small number of outcrop samples (23 samples from 16 locations) (Niem and Niem, 1990). The sample locations are scattered across the basin. Measured porosity and permeability values were highest in the Flournoy Formation followed by the Roseburg Formation turbidites (undifferentiated Umpqua Group of Ryu and others, 1992) and the Lookingglass Formation. No measurements were performed on samples from any other formations in the study area (Newton,

TABLE 4: POROSITY AND PERMEABILITY OF OUTCROP SAMPLES. (revised from Niem and Niem, 1990)

Geologic Unit

Flournoy

Roseburg

Lookingglass
Porosity (\%)

Avg. Std. Dev. $n$

$17.5 \quad 12.7$

$10.3 \quad 9.4$

7.0
Permeability (md) Avg. Std. Dev. n

$34.9 \quad 44.6 \quad 12$

$\begin{array}{lll}33.8 & 19.0 & 3\end{array}$


1980; Niem and Niem, (1990), reporting results of Mobil, 1980). New analyses of over 50 porosity and permeability samples from all the formations and members of the Tyee basin are now underway (1.-C. Ryu, personal communication, 1995).

In a brief review of earlier diagenesis studies Niem and Niem (1990) concluded that the porosity and permeability of both the Eocene units of the Tyee basin (Table 4) and the upper Jurassiclower Cretaceous units of the adjacent northern Klamath Mountains are generally low. This was attributed to burial compaction and to extensive diagenesis which formed clay minerals and pore-filling cements through chemical alteration of unstable lithics (volcanic and metamorphic) and feldspathic minerals in the sandstones (Burns and Ethridge, 1979). Chan (1985) suggested high rates of erosion and a lack of chemical weathering before rapid redeposition as a possible cause of the formation of the abundant chemically unstable lithic fraction which would be subject to extensive diagenesis in the sandstones (Galloway, 1974). In addition, authigenic mineralization was in part facies controlled; welldeveloped clay and zeolite cements are abundant in deltaic and shelf to inner-fan facies. Local carbonate cements occur in sandstones of many facies. Outer fan (turbidite) sandstones, with less original porosity and permeability and more detrital clay matrix, have less well-developed clay and zeolite cement, and are generally less cemented than near-shore facies. Secondary porosity was found to be rare (Chan, 1985). A more extensive study 
of the diagenesis of Tyee basin units is now underway (1.-C. Ryu, personal communication, 1995).

The most recent field studies (Ryu and others, 1992; A. Niem, personal communication, 1994) have suggested that potential reservoir sandstones are best developed in the older and youngest shelf-deltaic facies and more quartzo-feldspathic units. Examples are the lower part of the Tyee Mountain Member turbidite facies of the Tyee Formation, the Coquille River Member of the White Tail Ridge Formation, the coarse-grained distributary channel sandstones of the Remote Member of the White Tail Ridge Formation, and the Spencer and Bateman Formations. These units are concentrated in the southern part of the basin, and wedge out, are erosionally cut out, or undergo facies changes to slope mudstones and deeper marine less porous and permeable turbidites to the north (Niem and Niem, 1990; Ryu and others, 1992; A. Niem, personal communication, 1994).

Other convergent margin basins (e.g. California) have produced commercial quantities of gas from similar, seemingly tightly cemented, lithic and quartzo-feldspathic sandstones (Niem and Niem, 1990). Secondary fracture porosity produced by tectonic activity could be a factor in such production, and certainly could be present in the Tyee basin. If such fracturing is present, hand specimens that have been examined to date may not be typical of the units at depth (Niem and Niem, 1990). 
Cap Rocks and Seals

In the Tyee basin there are numerous thick marine mudstone members that either overlie or are locally up dip from potential sandstone reservoirs. The Bushnell Rock Formation and its Slater Creek sandstone member are both overlain by the Tenmile Formation, which contains thick sequences of deep-marine mudstone and tight turbidite sandstone. The Camas Valley Formation mudstone overlies the sandstones of the Remote and Coquille River Members of the White Tail Ridge Formation. They pinch out against, and locally onlap, the Siletz River Volcanics of the Reston High, which is overlain by the Camas Valley mudstone seal. The sandstone-dominated Rasler Creek tongue of the White Tail Ridge Formation conformably overlies the Coquille River Member in the southernmost part of the basin, but farther north is entirely enclosed by the Camas Valley mudstone. In general, the members of the Bushnell Rock and White Tail Ridge Formations pinch out toward the north against the mudstones and turbidites of the undifferentiated Umpqua Group (Molenaar, 1985; Ryu and others, 1992). The Umpqua Group rocks are of varying clay percentage, but are generally finer-grained toward the north (Ryu and others, 1992). The progradational lowstand submarine fan facies of the Tyee Mountain Member (Tyee Formation) also fines to 
the north and its beds thicken up section. It is overlain by the massive mudstone of the Hubbard Creek Member.

Structural Traps

A map and cross-sections of the southern Tyee basin have been compiled by Niem and Niem (1990) from numerous sources, including seismic lines, study of aerial photographs, and preliminary field mapping. More detailed mapping has been completed and will soon be available (A. Niem, personal communication, 1995). Niem and Niem (1990) report that both structural and stratigraphic traps are abundant in the basin. There are several untested anticlines and fault-bounded blocks that could act as structural traps.

Oil and gas shows have been reported in the southern part of the basin in oil and gas exploration wells, water wells and natural seeps (Niem and Niem, 1990). Some of these occurrences appear to be associated with thrust and high-angle reverse fault zones (Niem and Niem, 1990). Imbricate northeast-southwest striking thrust faults and high-angle reverse faults are numerous in the southern part of the basin and are commonly segmented by high-angle reverse or oblique-slip faults. A few asymmetric folds have also been mapped (Niem and Niem, 1990). The intensity of folding and faulting increases toward the Wildlife Safari Fault, near the 
southern edge of the outcrop area of Eocene strata (fig. 10). The Wildlife Safari reverse fault has been interpreted as the suture between Mesozoic Klamath Mountain terranes and accreted Tertiary ocean-floor volcanics (Ryberg, 1984; Ryu and others, 1992; A. Niem, personal communication, 1994). Movement on the fault was oblique; it is estimated to have five $\mathrm{km}$ (three $\mathrm{mi}$ ) of right-lateral separation (Ryberg, 1984). Niem and Niem (1990) suggest that some of these oldest faults, that were active during the early stages of formation of the basin, may have been reactivated by oblique-slip motion when subduction began farther to the west on the outer continental shelf/slope of Oregon. The Canyonville Fault Zone, for example, offsets Klamath terrane rocks as much as $40 \mathrm{~km}(25 \mathrm{mi})$ and may have involved the Bushnell Rock and Tenmile Formations and lower members of the White Tail Ridge Formation as well (fig. 10) (Perttu, 1976).

In the northern part of the study area folding is more open, with broad synclines, and anticlines with Siletz River basalts in their cores. Preliminary study of seismic lines in the central and northern parts of the study area suggests that many thrusts and volcanic-cored folds extend beneath the relatively undeformed forearc strata of the White Tail Ridge and Tyee Formations (Niem and Niem, 1990). Preliminary study by Niem and Niem (1990) also suggests that a few small, local, normal and reverse faults may have broken the Tyee, Elkton and Bateman Formations into small fault blocks with opposing attitudes. 
Stratigraphic Traps

The formation of stratigraphic traps was a possibility during most stages of the development of the Tyee basin. Control of depositional facies by tectonics and by the Siletz River Volcanic paleo-high has been suggested by several investigators. Perttu (1976) described both deformational and depositional effects of tectonic activity during the Eocene. Heller and Ryberg (1983) argued that compositional changes within the sandstone section documented the transition from subduction zone to forearc basin deposition. Perttu and Benson (1980) measured paleocurrent indicators that implied growth of folds during deposition of Umpqua basin sediments around and over them.

Numerous stratigraphic traps may occur in the Tyee basin through pinch-out of sandy facies by mudstone facies. Investigators studying deposition of sediments have repeatedly recognized thinning and fining of units across the basin, depositional facies changes and various effects of paleogeography (Lovell, 1969; Baldwin, 1974; Chan and Dott, 1983; Heller and Dickinson, 1985). Ryu and others (1992) documented relationships that could produce stratigraphic traps including scour and fill, pinchouts, interfingering, upward fining and upward thinning of parasequences. Depositional facies changes involving nearly every 
potential reservoir unit in the section have been observed.

Progradational and retrogradational sequences, disconformities, and angular unconformities characterize the sedimentary section (Ryu and others, 1992; 1.-C. Ryu, personal communication, 1994).

\section{SOURCE ROCKS}

A number of depositional units in the southern Tyee basin could be source rocks for oil andlor gas. The Camas Valley Formation is predominantly shallow-marine to deep-marine slope mudstone. The Tenmile Formation and the Hubbard Creek Member of the Tyee Formation are both deep marine slope mudstones. Basinal mudstones of the undifferentiated Umpqua Group are principally found north of the Umpqua Arch (fig. 10). A locally thick section of these mudstones and subordinate turbidite sandstones is present south of the Umpqua Arch and east of the Reston High in the Myrtle Point-Sutherlin sub-basin (Ryu and others, 1992). This greater than $1525 \mathrm{~m}(5000 \mathrm{ft})$ thick sequence may be an overthickened and repeated section, owing its presence so far south to underthrusting (Ryu and others, 1992). Subduction processes may have transported blocks of Umpqua Group mudstone to still greater depths. If interpretation of the Wildlife Safari Fault as the underthrust boundary between oceanic and continental rocks 
is correct, Umpqua Group mudstones may even occur beneath the pre-Tertiary Klamath Mountain rocks (Niem and Niem, 1990).

Sequence stratigraphic concepts can be used to predict spatial and stratigraphic positions of the best source rocks. Two key factors are the type of organic matter and the sedimentation rate (Creaney and Passey, 1993). Different types of organic matter have different potentials for oil and gas production. Generally, marine organic matter has potential for oil and gas production, while terrestrial organic matter is much less productive and produces only gas. Sedimentation rate is important because high rates of sedimentation generally result in low organic matter concentrations. There may be a minimum organic matter concentration below which oil and gas cannot be expelled from a source rock (Hinch, 1980). The best source rocks will occur in marine environments where the sedimentation rate is very low. The end of a transgressive phase, prior to highstand progradation, provides these conditions. The marine environment attains its farthest landward position at the end of the transgressive phase (fig. 15), and because of rising sea level, there is no shortage of space (accommodation space) in which sediment can accumulate nearshore. Very little sediment can reach the deeper basin under these conditions. Low basinal sedimentation rates can prevail into the highstand phase if compaction or subsidence maintains sufficient accommodation space to defer progradation of terrestrial sediments (Wignall, 1991; Wignall and Maynard, 1993). The thin, 
potentially organic-rich, predominantly marine sediment that

accumulates in a sediment starved basin near the end of a transgressive phase is known as a condensed section (Loutit and others, 1988). The Tenmile Formation, the Camas Valley Formation and the Hubbard Creek Member of the Tyee Formation may all be parts of transgressive systems. All are interpreted as deep-marine, slope mudstones (Ryu and others, 1992). The central portions of these units, deposited when transgression had reached its most landward position, and before progradation of overlying units had begun, should be the most organic rich (Creaney and Passey, 1993).

The Camas Valley and Tenmile Formation mudstones both grade northward into the deep-water mudstones of the undifferentiated Umpqua Group. These mudstones might be expected to be good source rocks. Ryu and others (1992) also describe a condensed section of Umpqua Group sediments developed on the paleotopographic high of the Umpqua arch. While less than $60 \mathrm{~m}(200 \mathrm{ft})$ thick, it contains a vertical sequence of foraminiferal assemblages identical to those found in the over 1200 m (4000 ft) thick section in the Myrtle Point-Sutherlin sub-basin.

Many exploration wells in the basin have had shows of oil and gas (Olmstead, 1989; Niem and Niem, 1990). The Long Bell 1 well in the northern part of the study area had several oil and gas shows in sedimentary interbeds in the Siletz River Volcanics (Table 1, no. 1). Niem and Niem (1990) also compiled a list of 11 localities where oil and gas seeps or shows in water wells have occurred and five 
localities where surface seeps have been reported. Most of these have been within a fairly small area in the south-central part of the basin, and most are either along or between the Wildlife Safari and Bonanza thrust faults (fig. 10). These faults could be transporting fluids from depth (I.-C. Ryu, personal communication, 1994).

Alternatively, oil and gas shows could originate from coal beds in the basin (A. Niem, personal communication, 1994). Two coal seams, each about two meters (six ft) thick, occur in the southwest part of the study area. They have been studied for possible exploitation and are believed to contain $\mathbf{5 0}$ million tons of coal (Niem and Niem, 1990). Numerous other, very much smaller, scattered occurrences of coal have been noted in the deltaic facies of the Tyee and White Tail Ridge Formations. Niem and Niem (1990) suggest that many other coal seams probably exist, but because of thick forest, soil cover, and low resistance to weathering, have gone unnoticed.

\section{DATA AND ANALYSIS}

Organic Richness

The organic richness of a source rock involves two factors: the quantity of organic matter and the quality of organic matter. The absolute quantity of organic matter is determined from TOC 
analysis. The quality of the organic matter is determined from its type (e.g. marine vs terrestrial), since different types of organic matter have very different abilities to generate hydrocarbons. When these factors are considered along with the maturation level, generative history and potential for further generation of hydrocarbons an overall picture of the hydrocarbon potential of the basin should result.

Average TOC values and standard deviations for the different wells and measured sections are given in Table 5 . Values for individual samples are tabulated with lithologic and stratigraphic data in Appendix A. Determinations of the statistical significance of the various means, correlations and best-fit line slopes discussed below were made using tests at the $90 \%$ significance level in all cases (probability of an incorrect decision one in 10).

The quantity of organic matter in samples from the Tyee basin is consistently below 1.0 weight percent (Appendices $A$ and $B$ ). The average TOC for the 63 non-coal samples is 0.51 weight percent. Variation from this mean is not great (standard deviation $0.18 w t \%$ ).

In the Great Discovery 2 well TOC values are greater at depth (fig. 18), in the Umpqua Group mudstones (average 0.61 wt\%) (standard deviation $0.15 \mathrm{wt} \%$ ), than in the overlying Bushnell Rock and White Tail Ridge Formations (average 0.39 wt\%) (standard deviation $0.07 w t \%)$. Despite the small number of samples $(n=6)$, the $t$ test of the data indicates that a significant difference between the two means has been established. That is, the average organic 
TABLE 5: AVERAGE TOC.

Source of Samples

All Non-Coal Samples

Great Discovery 2

Long Bell 1

Liles 1

$S \operatorname{cott} 1$

Glory Hole 1

Section 7

All Coals
Average TOC

(wt \%)

0.51

0.50

0.43

0.63

0.35

0.68

0.54

29.86
Std. Dev. n

(wt \%)

0.18

61

0.16

6

$0.18 \quad 14$

0.05

14

10

0.15

0.18

4

0.21

13

8.32

3

richness of the Umpqua Group mudstones is significantly greater when compared to the overlying units in the Great Discovery 2 well.

In the central part of the Long Bell 1 data sequence, in the middle of the Umpqua Group, a gradual increase to a peak TOC value of $0.73 w t \%$ can be seen (fig. 19). The entire sampled interval averages TOC 0.43 wt $\%$ (standard deviation $0.18 w t \%$ ).

Measured TOC values from the Liles 1 well, also in undifferentiated Umpqua Group, average 0.63 wt\% (standard deviation $0.05 w t \%$ ) (fig. 20). The mean TOC of the Liles 1 data is nearly as high as the highest TOC found in the Long Bell 1 well. The difference in the means of the Liles 1 and Long Bell 1 TOC data is 
Great Discovery 2

TOC v DEPTH

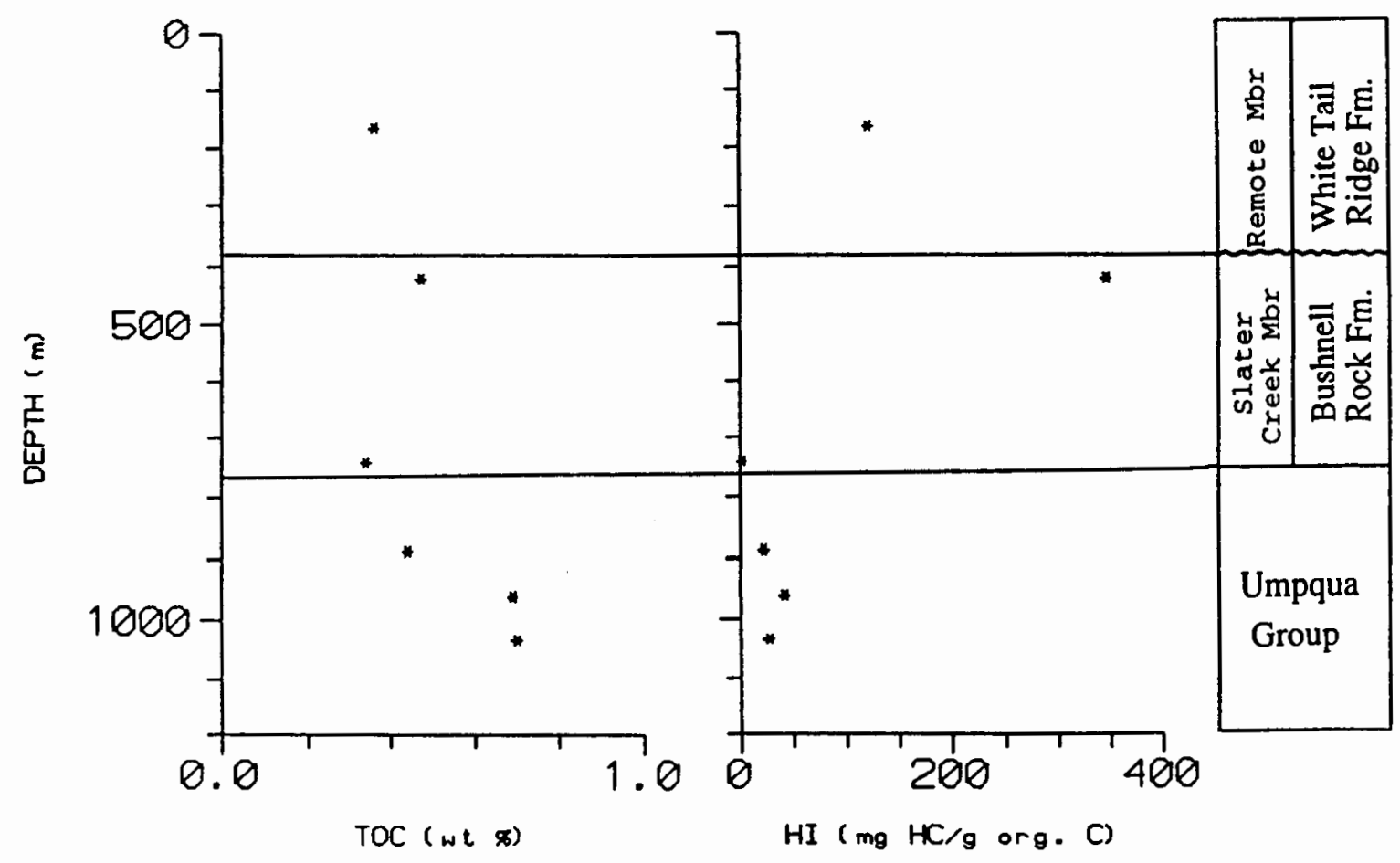

Figure 18: TOC and HI vs Depth for Great Discovery 2 well.

significant. The $t$ test comparing the two means shows that the difference in results between the two wells is not random sampling variation, but instead indicates a greater organic richness of the Umpqua Group sediments in the Liles 1 well when compared to the Long Bell 1 well. 


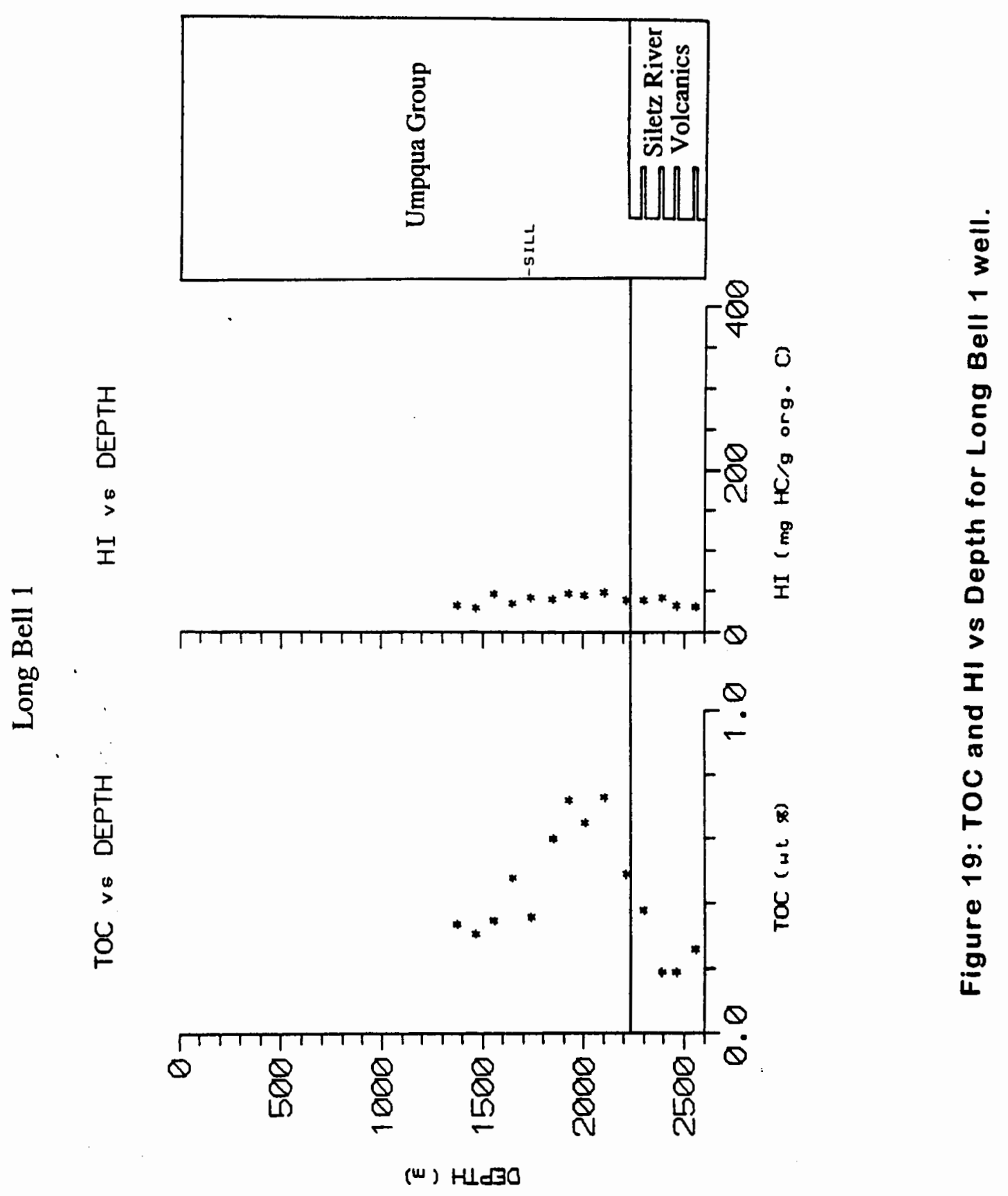




\section{Liles 1}

TOC VE DEPTH

HI ve DEPTH
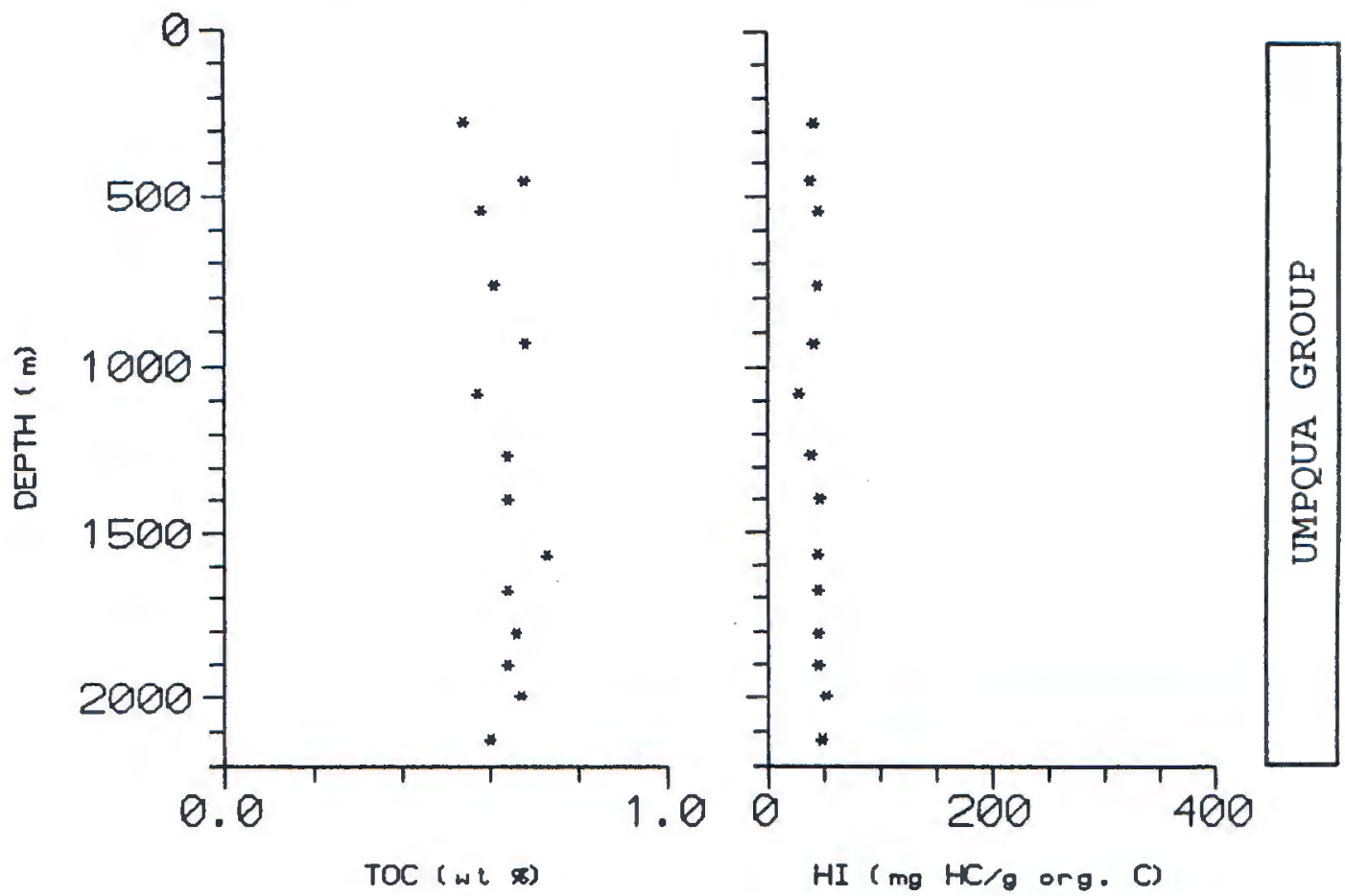

Figure 20: TOC and HI vs Depth for Liles 1 well.

TOC values from the Scott 1 well (fig. 21), from the Bushnell Rock Formation, are generally the lowest of those sampled (average $0.35 w t \%)$ (standard deviation $0.15 w t \%)$. The $t$ test indicates that these values are significantly lower than the average of all the samples from all the wells. 


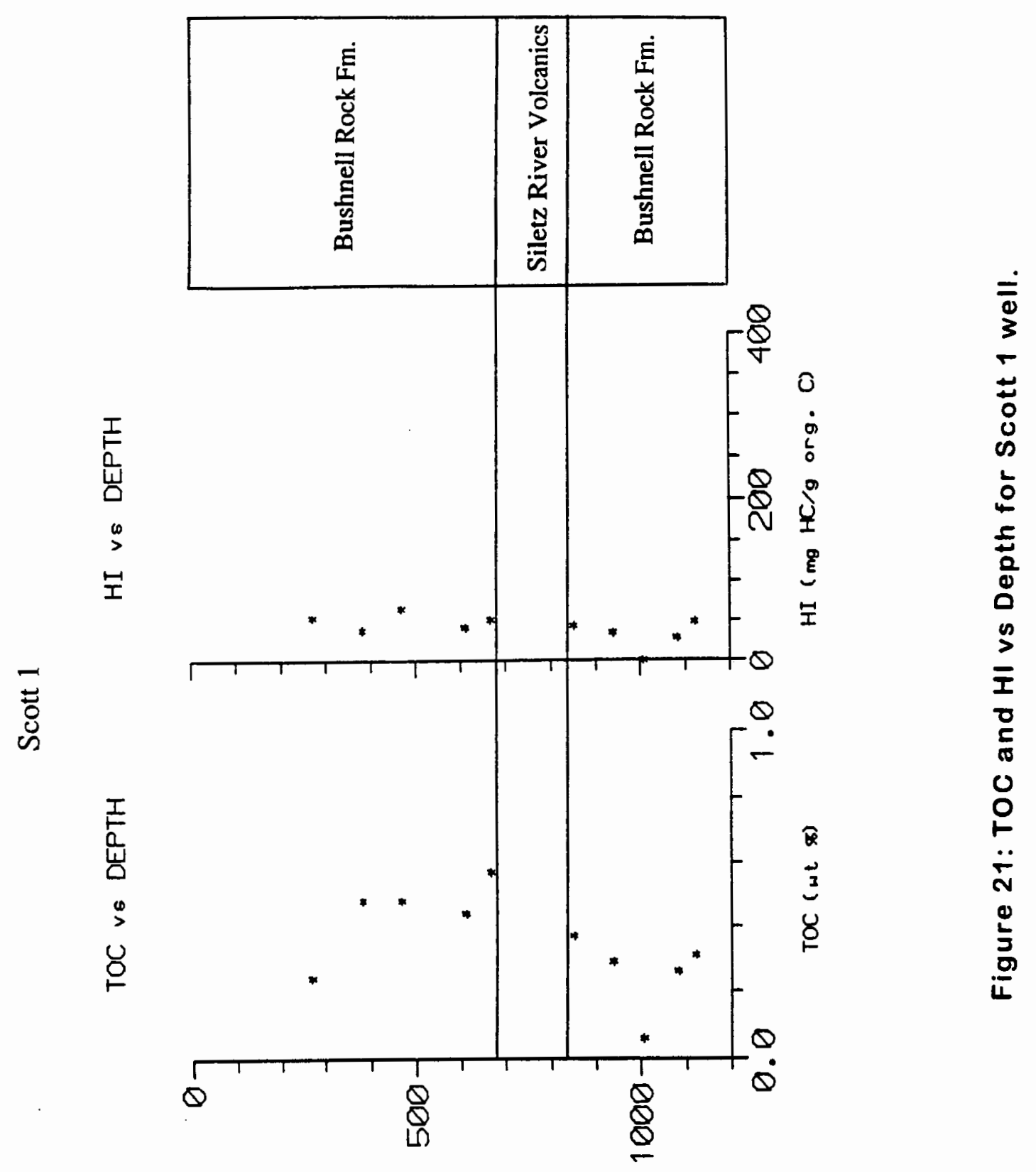

(w) $\mathrm{HLd} 3 \mathrm{O}$ 
Glory Hole 1
TOC ve DEPTH
HI ve DEPTH
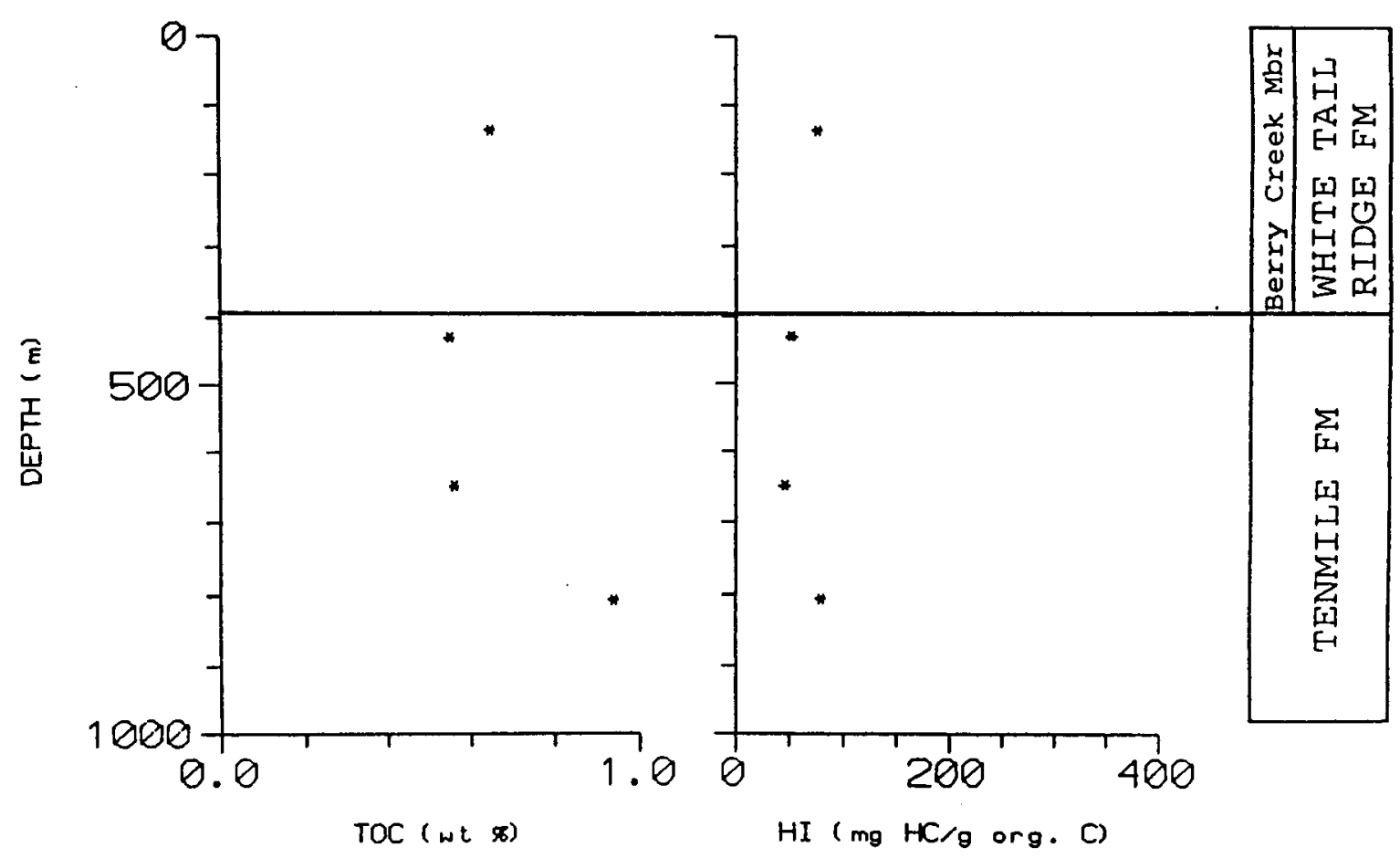

Figure 22: TOC and HI vs Depth for Glory Hole 1 well.

The highest values found (average TOC 0.68 wt\%) (standard deviation $0.18 w t \%)$ are from the Tenmile Formation and the Berry Creek Member of the White Tail Ridge Formation in the Glory Hole 1 well (fig. 22). Although the number of samples is small $(n=4)$ the $t$ test of the data indicates that the Glory Hole 1 samples are significantly more organically rich than the average found in this study. 
TOC values from outcrop samples (fig. 23) averaged 0.54 wt $\%$ (standard deviation 0.21 wt\%). Two outcrop samples (RN-91-396 and RN-91-253) (Appendix A) from the transgressive upper Camas Valley Formation have higher values than most others measured (0.74 and 0.82 wt\% respectively).

Two coal outcrop samples (R-92-027 and RN-91-270) (Appendix A) were analyzed and found to have TOC values of 34.26 and 45.58 weight percent. TOC measurement of a shaly coal (R-92017) (Appendix A), at 9.74 wt\%, reflects dilution of coal by shale. A plot of hydrogen and oxygen indices (HI vs OI) (fig. 24) shows that the organic matter in nearly all of the analyzed samples is type III or type IV kerogen (Espitalie and others, 1977). Type III includes woody and coaly kerogen. Type IV (inertinite) is organic material that has been thoroughly oxidized and has no remaining genetic potential. Some samples that plot below the type III line may do so because of the effects of low TOC, which has been shown to cause a lowering of $\mathrm{HI}$ values due to adsorption of pyrolysis products by minerals in the sample (Peters, 1986). This plot (fig. 24) includes all samples analyzed in this study, which are from various parts of the basin (fig. 2) and several different rock units (Appendix A). The results are entirely consistent with those of Law and others (1984) who used only outcrop samples from various locations in the southern Tyee basin.

Only one sample (51-010) is truly an exception, having a hydrogen index of $346 \mathrm{mg} \mathrm{HClg}$ TOC, much higher than any other 


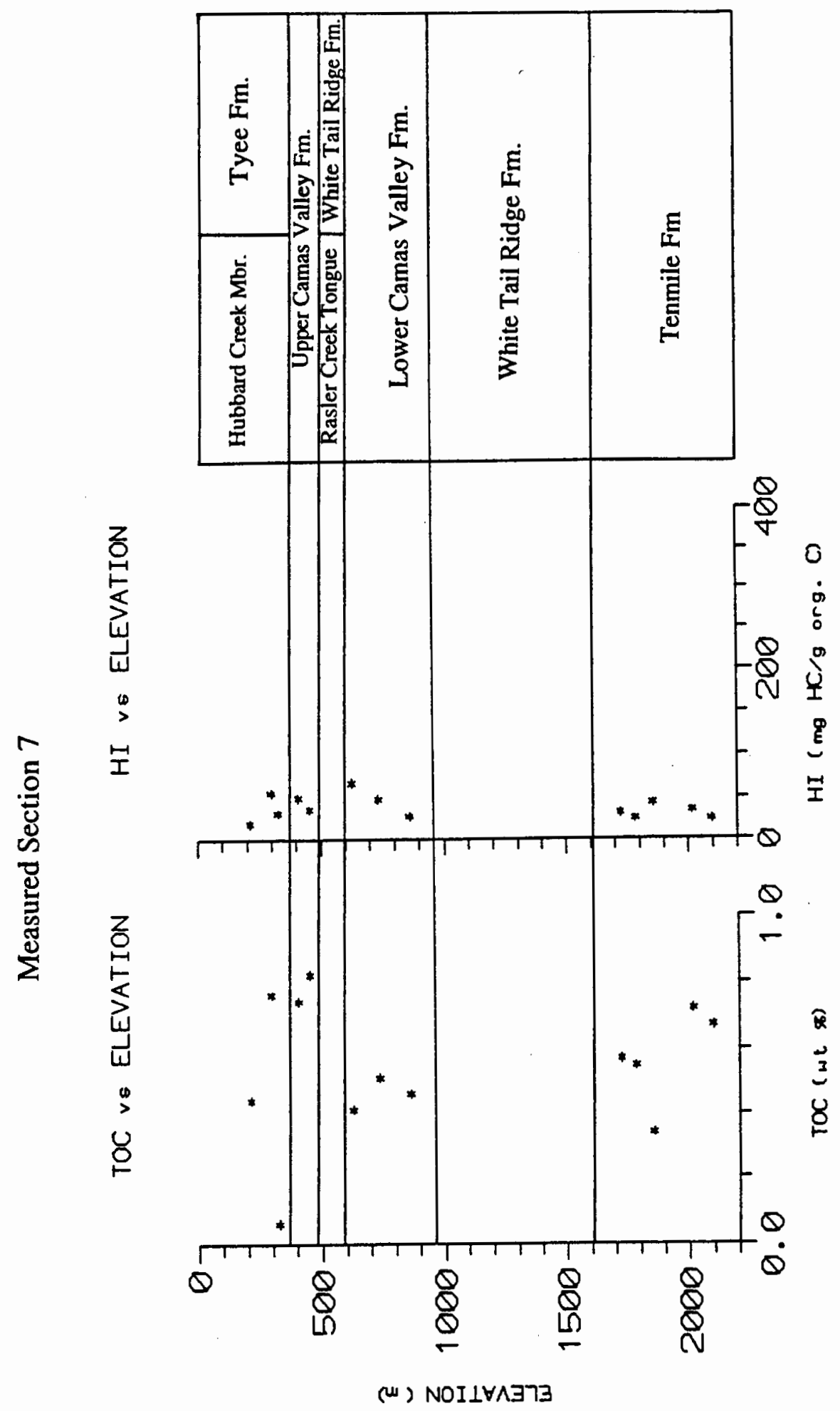

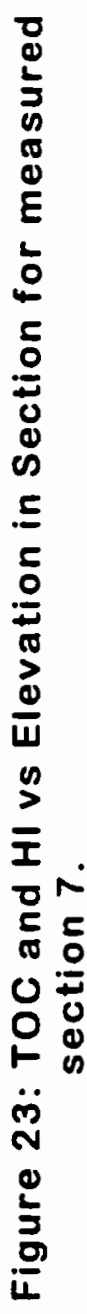


ALL SAMPLES

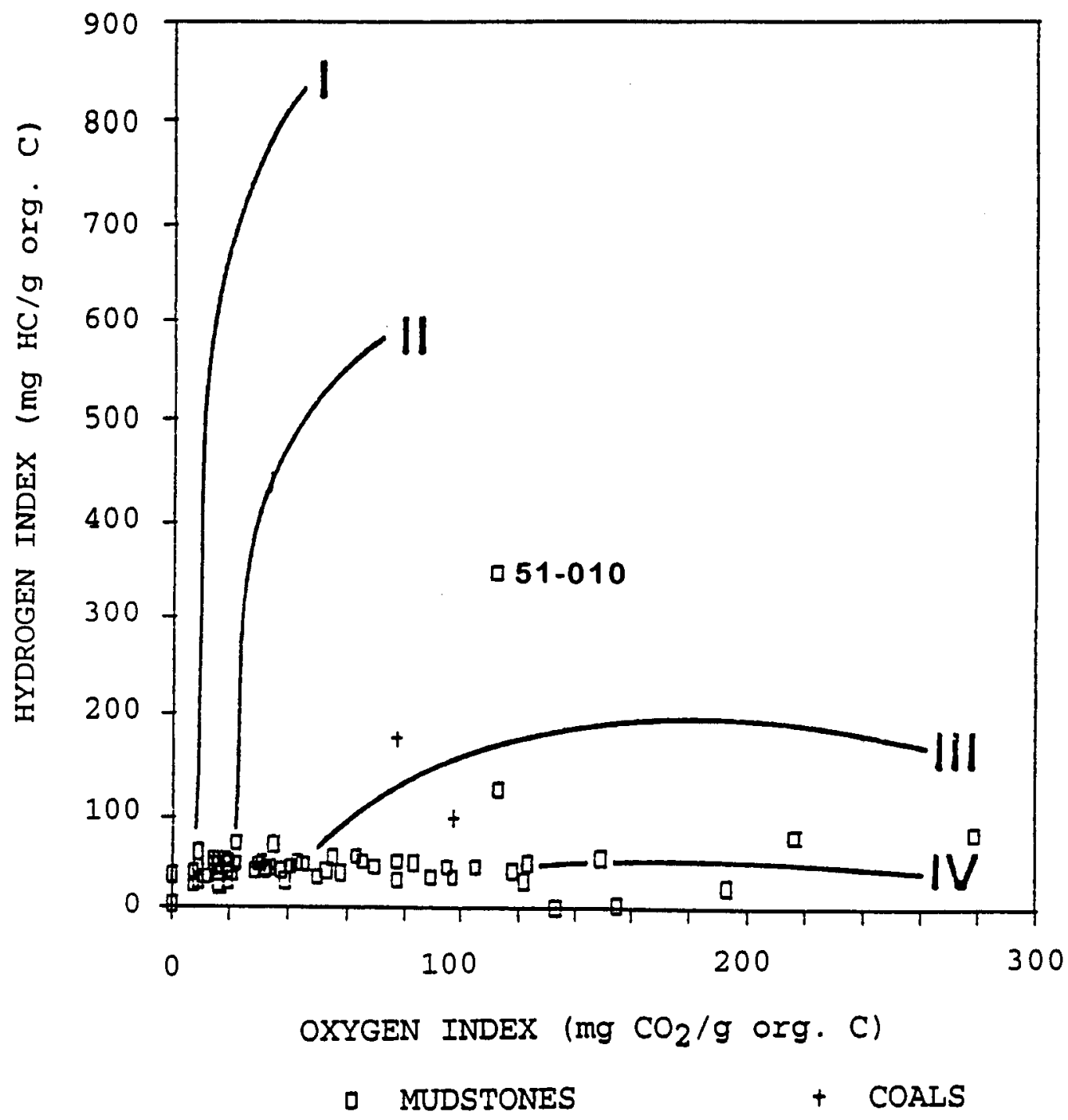

Figure 24: HI vs Ol for all samples.

sample in the study. This sample (51-010) falls far from any of the organic matter evolution pathways (fig. 24), which could be the result of mixing of type 11 and type III organic matter. Alternatively, 
its position on the graph could be the result of partial oxidation of type II organic matter (causing its plotted position to move to the right from the type II line). Oxidation can cause an elevation of Tmax (Peters, 1986), and at $507^{\circ} \mathrm{C}$ (Appendix B), Tmax for 51-010 is anomalously high. The coal samples do not stand out dramatically from the other samples, having only slightly higher hydrogen indices (fig. 24).

Since the evolution of oil or gas from kerogen requires substantial releases of hydrogen and relatively little oxygen is produced, the hydrogen index is often used as a measure of the potential of a source rock. It should be considered along with TOC to develop a picture of organic richness, since the abundance and the type of organic matter combine to determine how much oil or gas can be produced by a given rock. HI is plotted alongside the TOC data for each of the wells or measured sections (figs. 18-23). The average of all non-coal samples is $47 \mathrm{mg} \mathrm{HC} / \mathrm{g} \mathrm{TOC} \mathrm{(standard}$ deviation $43 \mathrm{mg} \mathrm{HC} / \mathrm{g} \mathrm{TOC)}$. Average $\mathrm{HI}$ values and standard deviations for the different wells and measured sections are given in Table 6. Values for individual samples are tabulated with complete rock-eval pyrolysis data in Appendix B.

Based on accepted values of source potential as determined from hydrogen index (Table 7), almost all of the hydrogen index values for Tyee basin samples fall in a range indicating a small potential for gas production and no potential for oil production. 
TABLE 6: AVERAGE HYDROGEN INDEX.

Source of Samples
Average $\mathrm{HI}$ (mg HC/g TOC)
Std. Dev. (mg HC/g TOC) n

61

All Non-Coal Samples

47

43

131

6

39

6

14

43

6

14

40

18

10

Glory Hole 1

63

16

14

13

Section 7

39

107

62

3

TABLE 7: SOURCE POTENTIAL FROM HYDROGEN INDEX.

(Waples, 1985)

Hydrogen Index

(mg HC/g TOC)

$<150$

$150-300$

$300-450$

$450-600$

$>600$
Principal

Product

gas

oil and gas

oil

oil

oil
Relative

Quantity

small

small

moderate

large

very large 
Only two non-coal samples had average $H I$ values greater than 100 $\mathrm{mg} \mathrm{HClg} \mathrm{TOC.} \mathrm{Both} \mathrm{were} \mathrm{from} \mathrm{the} \mathrm{upper} \mathrm{part} \mathrm{of} \mathrm{the} \mathrm{Great} \mathrm{Discovery}$ 2 well. Sample 51-010, with an HI of $346 \mathrm{mg} \mathrm{HC} / \mathrm{g} \mathrm{TOC}$, is from the Slater Creek Member of the Bushnell Rock Formation and sample 51 $009(H I=122 \mathrm{mg} \mathrm{HC} / \mathrm{g} \mathrm{TOC})$ is from the Remote Member of the White Tail Ridge Formation.

The coal samples had $\mathrm{HI}$ values of 94 and $175 \mathrm{mg} \mathrm{HClg} \mathrm{TOC,}$ and the shaly coal $53 \mathrm{mg} \mathrm{HC} / \mathrm{g}$ TOC. These coal values (average 107 $\mathrm{mg} \mathrm{HC} / \mathrm{g}$ TOC) (standard deviation $62 \mathrm{mg} \mathrm{HC} / \mathrm{g} \mathrm{TOC}$ ) are higher than those of non-coals. But like the non-coals they are also in ranges indicating only a small relative quantity of possible production (Table 7). The highest of these values is in a range where a small quantity of oil production is possible (Table 7).

Visual kerogen analysis data are summarized in Appendix C. Averages of nearly $20 \%$ of the organic matter in the Scott 1 well, and more than $10 \%$ in the Liles 1 well, were found to be inertinite (type IV). Approximately $50 \%$ of the organic matter in both wells is vitrinite, which is terrestrial plant material, only some of which has significant oil potential, and the majority of which has only limited gas potential. Vitrinite encompasses type III and may contain some type Il organic matter (Table 2) (Waples, 1985). The HI index values show that the vitrinite in these samples is almost exclusively type 1II. The remainder of the organic matter, about $30 \%$ in both wells, is composed of lipids (primarily fats, oils and waxes) which are the 
main oil and gas productive components of organic matter.

Kerogens with less than about 35 percent lipids yield primarily dry gas, and oil source rocks usually contain greater than 65 percent of these oil generating components (Dow and O'Conner, 1981). The lipid level in these samples is consistent with the HI vs OI plot showing a very low potential from type III kerogen and a significant amount of inertinite.

TOC values found in this study indicate fair to poor source rocks, as defined in Table 8 . Both mudstones and coals classify as either fair or poor on the basis of TOC (Table 8). The low hydrogen index values indicate potential for only small quantities of gas (Table 7). Only two samples (51-010, a mudstone, and RN-91-270, a coal) had $\mathrm{HI}$ values greater than $150 \mathrm{mg} \mathrm{HC} / \mathrm{g} \mathrm{TOC}$, indicating potential for small quantities of oil (Table 7). Even sample 51-010 $(\mathrm{HI}=346 \mathrm{mg} \mathrm{HC} / \mathrm{g} \mathrm{TOC})$, in a hydrogen index range indicating potential for a moderate quantity of oil (Table 7), has a TOC value (0.47 wt\%) indicating a negligible source capacity (Table 8 ). Such rocks, with high $\mathrm{HI}$ values but low TOC, would need to be abundant to produce economic quantities of oil or gas.

The concentration of organic matter in the Tyee basin, as evidenced by TOC values, indicates slight source capacity (Table 8). The quality of the organic matter, evidenced by $\mathrm{HI}$, generally indicates potential for small quantities of gas. The fact that nearly all samples plot near or below the type 111 line (fig. 24) indicates a strong, lasting, terrestrial influence on sedimentation in the basin. 
TABLE 8: SOURCE POTENTIAL FROM TOC.

(modified from Waples, 1985 and Geochem Labs, 1980)

TOC Value (wt\%)

$<0.5 \%$

$0.5 \%-1.0 \%$

$1.0 \%-2.0 \%$

$2.0 \%-4.0 \%$

$>4.0 \%$
Rating

poor

fair

good

very good

excellent
Source Rock Implications

negligible source capacity

possibility of slight source capacity

possibility of modest source capacity

possibility of good to excellent source capacity

possibility of good to excellent source capacity

This terrestrial influence is undoubtedly also an important factor in the low concentration of organic matter. The stratigraphy and lithologies of the basin indicate high rates of sediment influx, resulting in the dilution of organic matter.

The presence of deep-marine mudstones at several levels in the stratigraphic column (Hubbard Creek Member of the Tyee Formation, upper Tenmile Formation, upper Umpqua Group) indicates temporary respites from this high rate of terrestrial sedimentation. The fact that organic matter is only slightly more concentrated in these rocks than it is in those with more terrestrial input may be due to degradation of the organic matter prior to 
burial. The presence of a large proportion of inertinite in all visually analyzed samples supports this interpretation. A low sedimentation rate by itself will not result in the concentration of organic matter if the other conditions for preservation are not met. If deep basin waters are well oxygenated, for example by longshore currents, the preservation rate may be very low. Under such conditions the formation of a non-deposition surface or submarine hardground can occur, where incoming organic material is rapidly oxidized or swept away (Creaney and Passey, 1993).

The coals clearly represent much better source rocks than any of the shales or mudstones examined in this or other studies (Law and others, 1984; Niem and Niem, 1990). While there is a reported tendency for pyrolysis to exaggerate the hydrogen index of coals (Peters, 1986), it is clear that the coals are the richest sources of organic matter found in the basin.

Maturity of Organic Matter

Measurements that reveal the maturity of organic matter include vitrinite reflectance (Ro), thermal alteration index (TAI), rock-eval pyrolysis Tmax and production index (PI). Two or more of these analyses need to be and commonly are performed on each sample for verification of results. 
Rock-eval pyrolysis results can be influenced by a variety of factors. An important factor in the evaluation of rock-eval pyrolysis data from the Tyee basin is the effect of low TOC. Low TOC (below about 0.4 to $0.5 \mathrm{wt} \%$ ) can reduce the volume of pyrolysis $S_{2}$ production and lower the Tmax temperature (Peters, 1986). A large part of the pyrolysis data for the Tyee basin is from samples with TOC lower than 0.5 weight percent. Tmax temperatures have also been shown to be dependent on the type of organic matter (Dow, 1977a). This dependence has been accounted for in Figure 25, where the ranges of oil and gas production are shown for different types of organic matter relative to the scales of several methods of maturation measurement. The onset of gas production is in the Tmax range of $465-470^{\circ} \mathrm{C}$ for type III kerogen (Tissot and others, 1987).

Systematic errors of two types were suspected to have occurred in the Tmax data for this study: variation of Tmax relative to TOC, and variation of Tmax relative to which lab performed the analysis. The statistics in Table 9 illustrate these points.

There theoretically is no required relationship between Tmax and TOC since Tmax is a measure of maturation, independent of the quantity of organic matter. A difference in $T$ max of $36^{\circ} \mathrm{C}$ between samples above and below TOC $=0.40$ wt $\%$ is enough to greatly effect data interpretation, as illustrated on Figure 25 where points $A$ and $B$ are plotted $36^{\circ} \mathrm{C}$ apart adjacent to the dry gas graphic. Point 


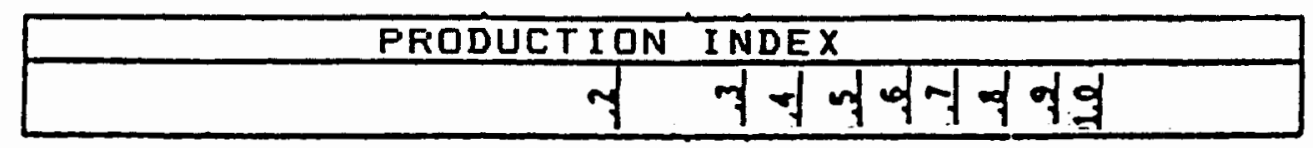
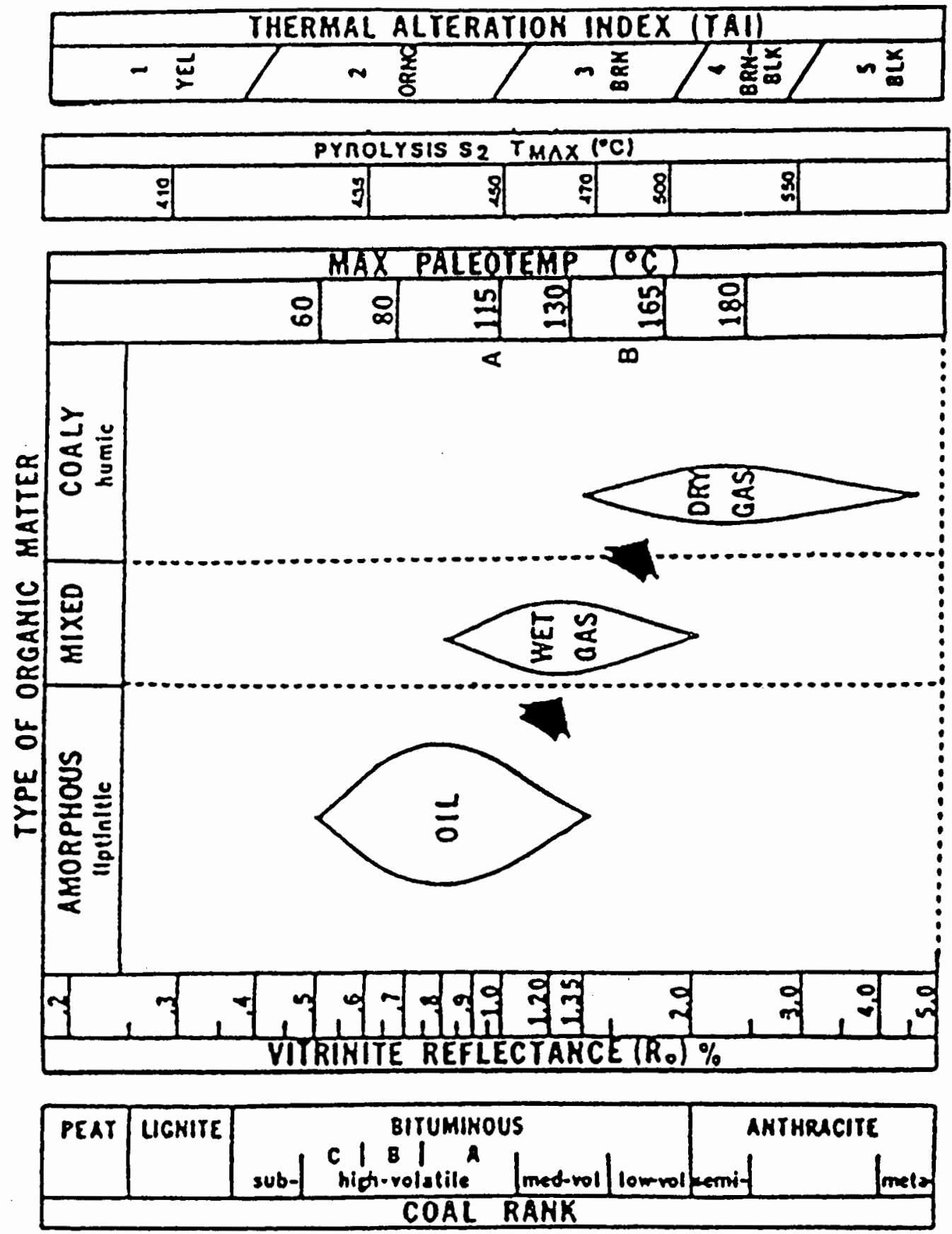

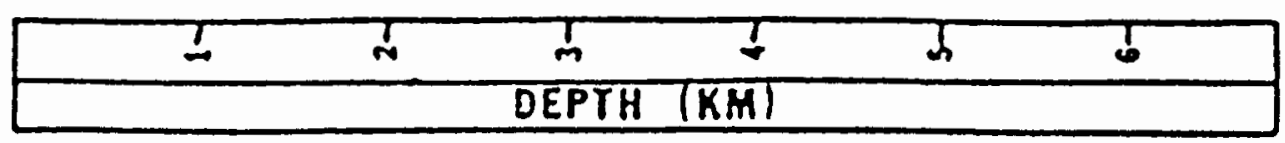


TABLE 9: SYSTEMATIC VARIATIONS IN TMAX DATA.

$\begin{array}{lrcccl}\text { Lab } & n & \begin{array}{c}\text { TOC } \\ (w t \%)\end{array} & \begin{array}{c}\text { Mean Tmax } \\ \left({ }^{\circ} \mathrm{C}\right)\end{array} & \begin{array}{c}\text { Std. Dev. } \\ \left({ }^{\circ} \mathrm{C}\right)\end{array} & \text { Sampled } \\ \text { DGSI } & 16 & <0.40 & 403 & 50 & \text { all DGSI samples } \\ \text { DGSI } & 38 & >0.40 & 439 & 29 & \text { all DGSI samples } \\ & & & & & \\ \text { DGSI } & 14 & >0.50 & 444 & 8.7 & \text { Liles } 1 \text { well* } \\ \text { USGS } & 8 & >0.50 & 431 & 3.7 & \text { Liles } 1 \text { well* }\end{array}$

*Additional USGS Liles 1 well data will be available at a later date (A. Niem, personal communication, 1994).

$A$ is at a temperature where no gas could have been produced by coaly or terrestrial organic matter, while point $B$ is within the range of dry gas production. The $t$ test of the Tmax means of the high TOC $(>0.4 w t \%)$ and low TOC $(<0.4 w t \%)$ sample sets indicates that there is a significant variation in Tmax, dependent on TOC level. Interpretive difficulties resulting from the effects of low TOC on Tmax results are considered on a case-by-case basis. Evaluation is aided by comparison to Ro, TAl and PI data.

There is an apparent discrepancy between the results of the two labs, observed during evaluation of the complete DGSI and USGS data sets. These data sets were selected to compliment rather than duplicate each other, sampling different rock units and in some cases different wells. The Liles 1 well was sampled in both data sets. When identical samples are analyzed a difference in results between labs of no more than $3-4^{\circ} \mathrm{C}$ is common since there 
are some differences between instruments and between the procedures of different labs (Peters, 1986). Liles 1 samples from the two labs were not identical in this case, but encompassed the same depth interval and all had TOC $>0.50$ weight percent.

Samples analyzed by DGSI averaged $13^{\circ} \mathrm{C}$ higher than those analyzed by the USGS. The $t$ test of the means indicates that the difference is within the range of random variation, not a significant difference in the results of the two labs.

Ro and TAl data are given in Appendix C and Tmax and PI data are compiled with other pyrolysis data in Appendix B. In evaluating the maturation data Ro, TAl, Tmax and PI are considered together for each well or measured section. The correlation chart (fig. 25) shows comparable values for the different techniques relative to the generally accepted maturation ranges of oil and gas formation. All of these maturation parameters can be expected to follow lognormal distributions and are plotted on semi-log graphs. The exception is the production index data for Glory Hole 1, Great Discovery 2, and the coal samples. These cases resulted in PI values of 0.0 , which cannot be plotted on a semi-log scale, and have instead been plotted on a linear scale. For statistical analysis of the results a transformation technique was used in which the measured values were converted to their logarithms. The logarithms were then used to calculate statistical quantities (Koch and Link, 1970; Duckworth, 1968). 
The Liles 1 well, in the central part of the study area, was sampled over a range of $1848 \mathrm{~m}(6063 \mathrm{ft})$ of undifferentiated Umpqua Group mudstones. Maturation indices (Tmax, Ro and PI) are plotted in Figure 26. With TOC values entirely above 0.5 wt\% (fig. 20) Tmax values can be expected to be reliable. The correlation coefficient is $r=0.50$ for the Tmax versus depth data. The $t$ test of $r$ indicates that there is a significant correlation between Tmax and depth in the Liles 1 well. The t test of the slope of the least-squares best-fit line indicates there is a significant increase in Tmax with depth in the well. The increase is not great enough, however, for any of the sediments in the sampled interval to attain the maturity level needed for gas production, based on the standard of $\mathrm{Tmax}=465-470^{\circ} \mathrm{C}$ for the onset of gas production.

The lowest sample at $2123 \mathrm{~m}(6960 \mathrm{ft})$ was the only one for the well with a reported TAl value. The TAl result of 2- (minus sign indicating lower maturity end of TAl range 2, fig. 25), indicates immature organic matter.

Vitrinite reflectance (Ro) values for the Liles 1 well are few in number $(n=5)$ (fig. 26). The t test of the correlation coefficient ( $r=$ $0.44)$ indicates no real correlation between Ro and depth, since Ro values are tightly clustered about the mean $(0.68 \%)$ with very little variation (standard deviation $=0.02 \%$ ). The mean of the Ro data corresponds (by reading across fig. 25) to a Tmax temperature of approximately $443^{\circ} \mathrm{C}$. The mean of the Tmax data is $447^{\circ} \mathrm{C}$. This 


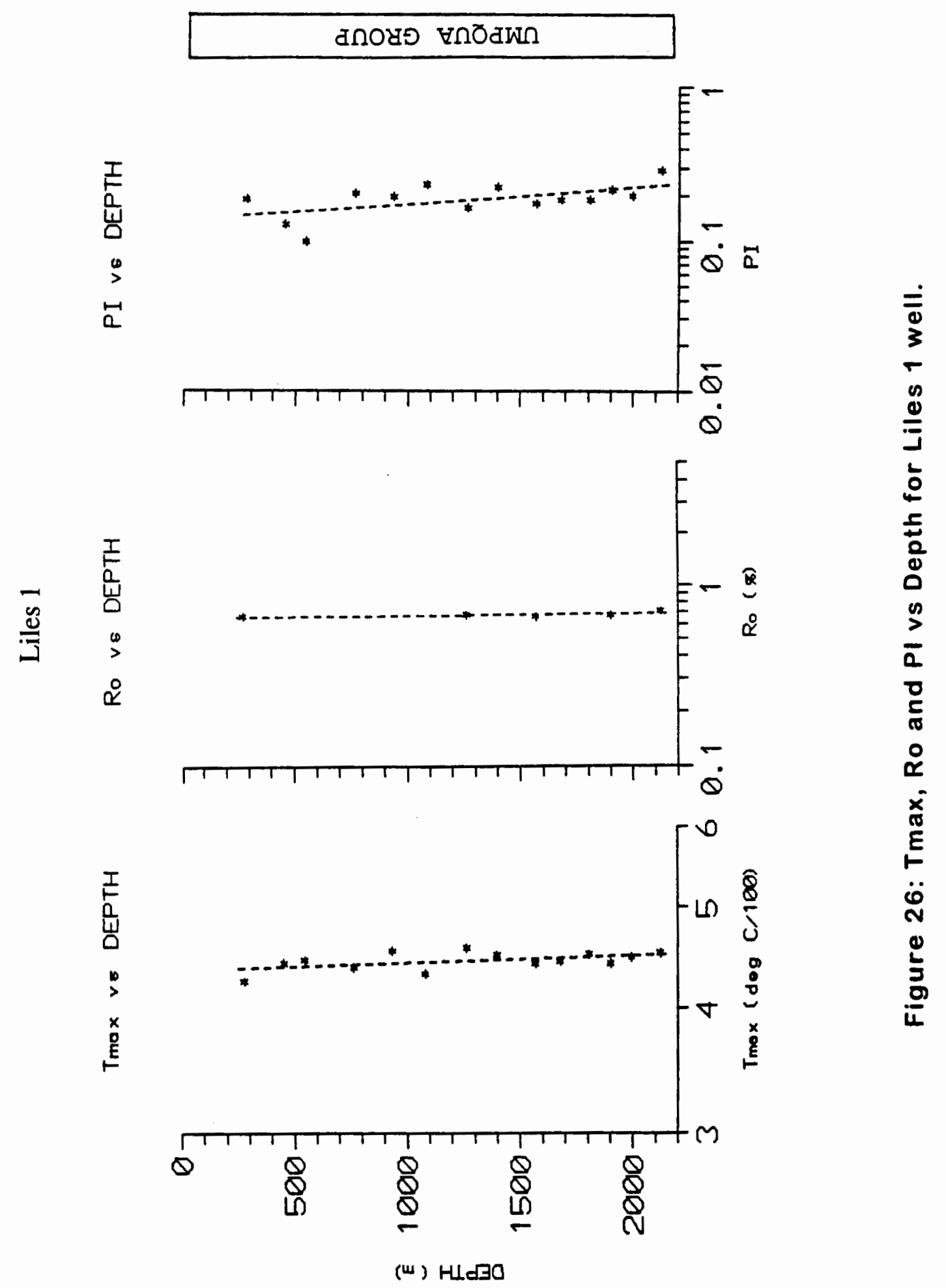


difference is within the range of expected variation between labs and is therefore considered to indicate an agreement of Ro and Tmax maturation data.

Oxidized vitrinite was observed by the microscopist (D. O'Conner, personal communication, 1994) for the deepest sample (L6960) and the two samples nearest the surface (L900 and L4140) of the Liles 1 well (Appendix E). Oxidation is reported to increase Ro measurements by 0.10 to $0.30 \%$ (Robert, 1988). This may account for at least part of the lack of variation in the reflectance data.

The correlation coefficient $(r)$ equals 0.57 for the production index data from the Liles 1 well. The $t$ test of $r$ indicates a significant correlation between $\mathrm{PI}$ and depth for this well. The $t$ test of the slope of the best-fit line confirms that there is a significant increase of PI with depth.

The PI values comparable to the Tmax gas production threshold of $465-470^{\circ} \mathrm{C}$ are $\mathrm{PI}=0.35-0.40$ (compare Tmax and $\mathrm{PI}$ scales, Figure 25). The highest PI value found among the Liles 1 samples was 0.29 at $2123 \mathrm{~m}(6966 \mathrm{ft})$, the deepest of the samples. The value determined from the equation of the best fit line at the same point is even lower $(0.23)$. This sample point is only $13 \mathrm{~m} \mathrm{(43}$ ft) above the bottom of the well, which is believed to be very close to the top of the Siletz River Volcanics (Ryu and others, 1992). Thus the PI data indicates organic maturity levels too low for gas 
production to have occurred in any part of the interval. The data from the Liles 1 well are all in agreement, indicating that sediments in the well are too immature for gas production to have occurred.

The Long Bell 1 well is in the northwest corner of the study area and like the Liles 1 well, has a thick $(840 \mathrm{~m}(2760 \mathrm{ft}))$ section of undifferentiated Umpqua Group mudstones overlain by the thick Tyee Mountain Member of the Tyee Formation. Long Bell 1 was drilled through a substantial thickness $(460 \mathrm{~m}(1509 \mathrm{ft}))$ of Siletz River Volcanics, underlying the Umpqua Group. It was drilled to a total depth of $2744 \mathrm{~m}(9003 \mathrm{ft})$ without re-entering sediments, except for relatively thin $(40 \mathrm{~m}(130 \mathrm{ft})$ or less) tuffaceous sedimentary interbeds (included in the Umpqua Group). The well was sampled over the entire Umpqua Group interval, including one sample from each of four interbeds.

Tmax values from the top of the Umpqua Group to the top of the Siletz River Volcanics, at about $2250 \mathrm{~m}$ (7400 ft), are plotted (fig. $27 a$ ) exclusive of the underlying interbed Tmax values. The $t$ test of $r(r=0.65)$ indicates a significant correlation to depth. The $t$ test of the slope indicates there is a significant increase of Tmax with depth. Below $2250 \mathrm{~m}(7400 \mathrm{ft}) \mathrm{Tmax}$ values drop off sharply (fig. $27 \mathrm{~b}$ ) corresponding with a reduction in TOC to an average of only 0.26 weight percent (fig. 19) in the interbed samples. When the four interbed data points are included the correlation between Tmax and depth changes to a negative one $(r=-0.52)$, and the $t$ test of $r$ indicates that the correlation is no longer significant. As the 


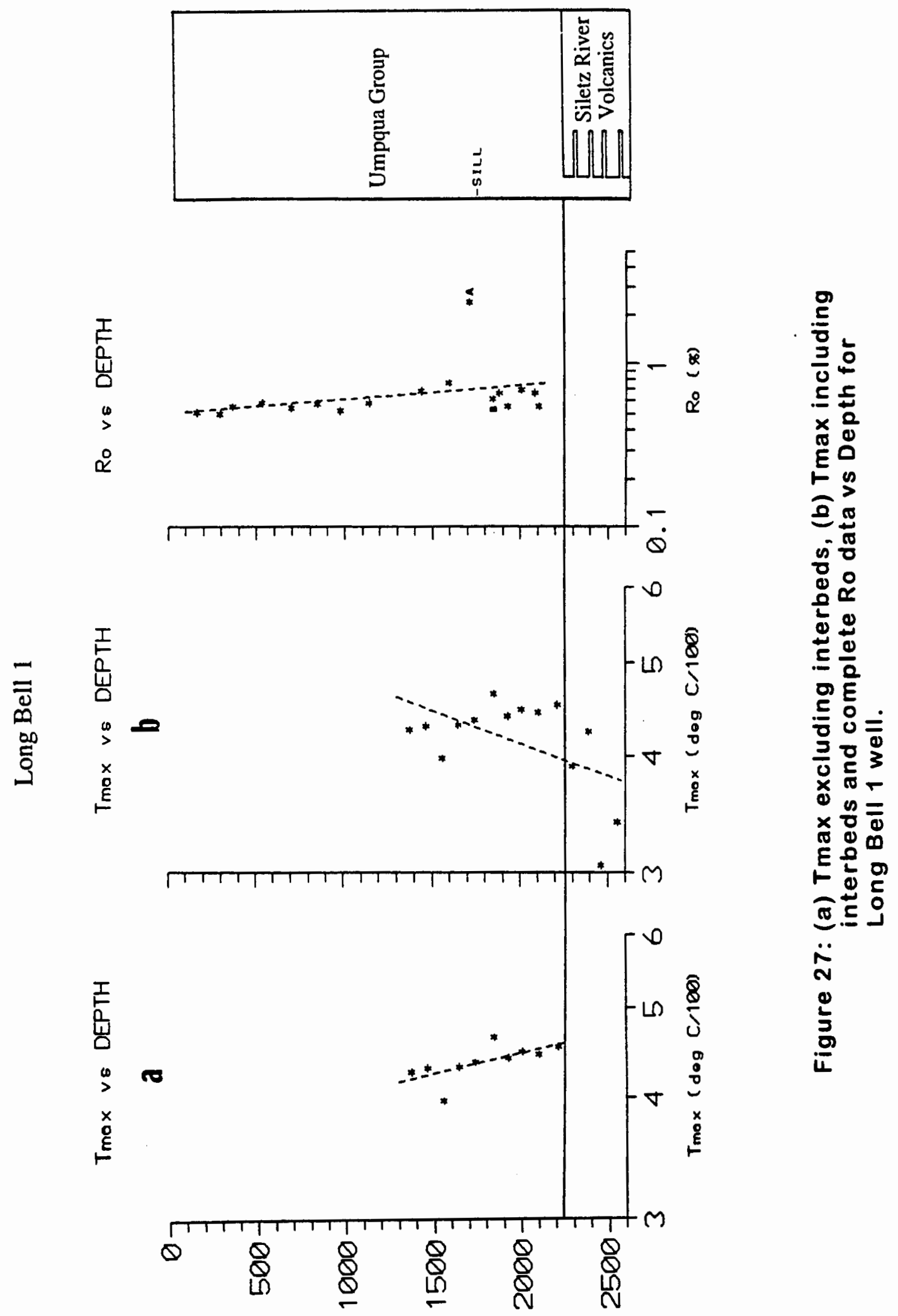

(w) $\mathrm{H} \perp d O$ 
effects of low TOC on Tmax data are well established, the Tmax values from the interbed samples have been excluded from figure 28 on which the best-fit line from the non-interbed data (fig. 27a) has been extrapolated downward to provide a tentative evaluation of the lower part of the well. This extrapolation indicates that at a depth of about $2500 \mathrm{~m}(8200 \mathrm{ft}) \mathrm{Tmax}$ temperatures would be sufficient to be within the dry gas production window. This depth is below the base of the Umpqua Group sediments and below three of the four interbeds. Therefore Tmax data indicates that the only sediments in the well mature enough to have produced gas are from a six $\mathrm{m}(20 \mathrm{ft})$ thick interbed near the base of the well. Calculation using the equation of the best-fit line of Tmax versus depth at the depth of the lowest interbed results in a projected Tmax temperature of $471^{\circ} \mathrm{C}$, high enough for production of gas to have begun.

Ro values for the Long Bell 1 well were obtained from a separate set of samples taken from the same interval. One value strikingly higher than the rest $(2.40 \%)$ is found at the $1706 \mathrm{~m} \mathrm{(5597}$ ft) depth (point A, fig. 27). A $15 \mathrm{~m}$ (49 ft) thick, Miocene or younger, basaltic sill occurs at $1739-1754 \mathrm{~m}(5706-5755 \mathrm{ft})$ and this vitrinite reflectance sample is reported to be baked (I.-C. Ryu, personal communication, 1994). These facts provide no clue as to why the sample at $1739 \mathrm{~m}$ (5706 ft) (point B, fig. 27), which should be right at the contact, shows no elevation in either Tmax or PI. 


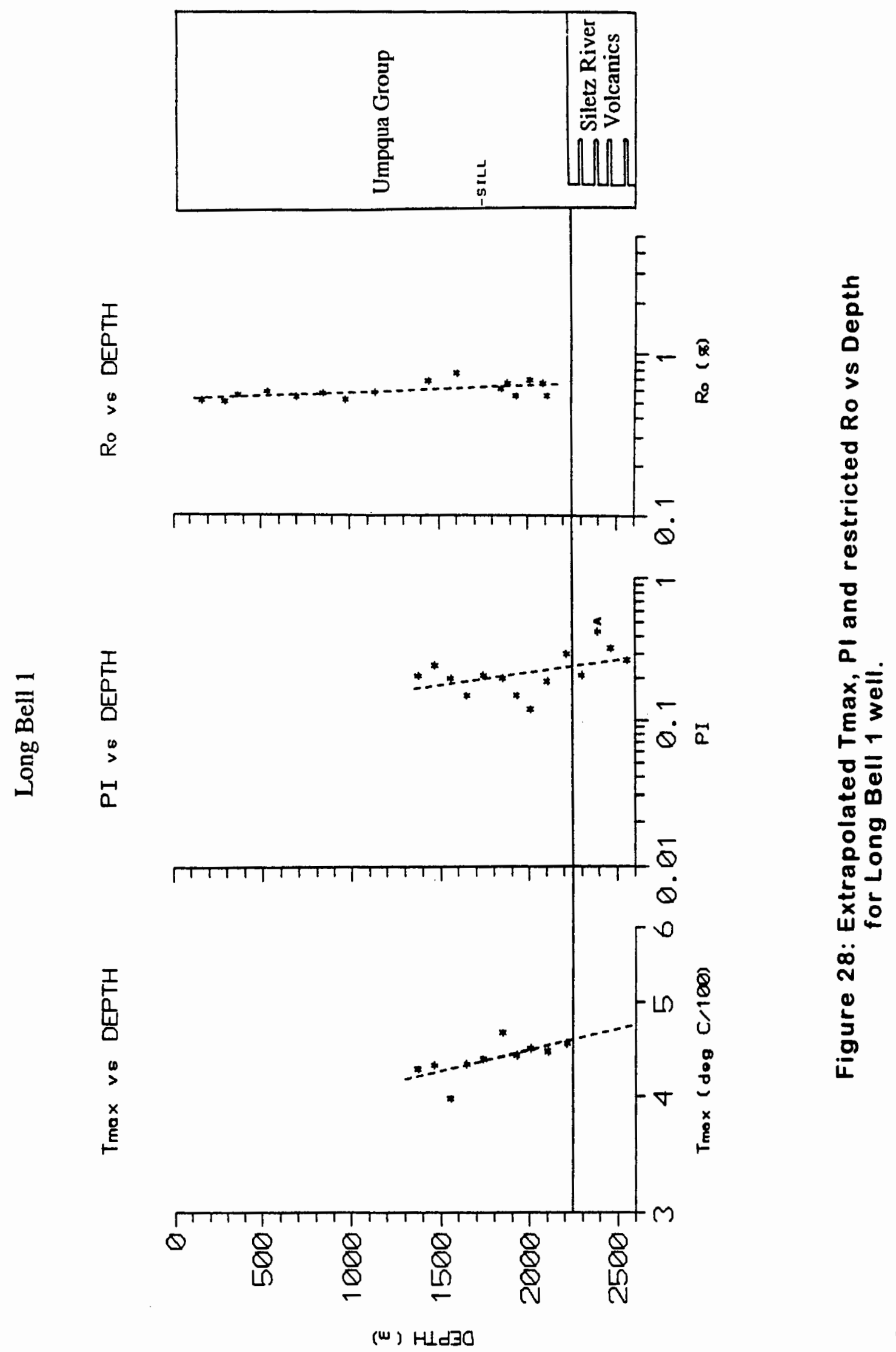


The one anomalous data point (point $A$, fig. 27) has a significant effect on the interpretation of the Ro data. If the data set is plotted with this point, then $r=0.36$ and the $t$ test of the correlation indicates that the possibility that the data are random cannot be rejected. With the anomalous data point removed $r=0.62$ and the test indicates there is a significant correlation between Ro and depth. This replotting of the data (fig. 28) allows consideration of the background maturation level separate from the effect of the localized intrusion. The $t$ test of the resultant slope of the best-fit line confirms that there is a significant increase of Ro with depth. Calculation using the equation of the best-fit line results in an expected Ro value of $0.68 \%$ at the depth of the lowest interbed in the Siletz River Volcanics. This is far below the Ro $=1.20 \%$ that would indicate the beginning of gas production (fig. 25).

PI values (fig. 28) result in a correlation coefficient of $r=0.47$ for the Long Bell 1 well. The t test of the correlation indicates that it is significant. The $t$ test of the slope indicates a significant increase of PI with depth. While one PI result (0.43) at $2391 \mathrm{~m}(7845$ ft) (point A, fig. 28) indicates maturity sufficient to produce gas, no other sample measured greater than 0.33. Calculation using the equation of the best-fit line indicates an expected value of only 0.28 at the base of the sampled interval. The PI data is therefore interpreted as indicating the sediments are too immature for gas production. 
Both Ro and PI data for the Long Bell 1 well indicate insufficient maturation for gas production at any sampled depth. Extrapolation of the Tmax data to greater depth indicates the possibility that one low TOC interbed near the base of the well might have reached a level of maturity just within the gas production window.

The Scott 1 well is located south of the Liles 1 well (fig. 2). Samples from this well were from the Bushnell Rock Formation. A $153 \mathrm{~m}(502 \mathrm{ft})$ thick section of Siletz River Volcanics in the middle of the sampled interval is interpreted as having been thrust into place, causing a repetition of the Bushnell Rock section (Ryu and others, 1992). The highest Tmax values are from near the thrusted volcanics, both above them and below them (fig. 29). This may be due to upward travel of warmer fluids from greater depths along fault planes, causing a localized increase in maturation.

Tmax values for the Scott 1 well are from samples with very low TOC (avg. 0.35 wt\%) (fig. 21). Tmax is not well correlated to depth $(r=0.20)$. The $t$ test of $r$ indicates that there is no reason to reject the conclusion that the data are random.

PI data are also scattered (fig. 29), showing very little relation to depth $(r=0.15)$. The $t$ test of the PI data shows that an interpretation of the results as random cannot be rejected. The lack of any significant correlation to depth for either the Tmax or PI results is attributable to the effect of Iow TOC on pyrolysis results. 


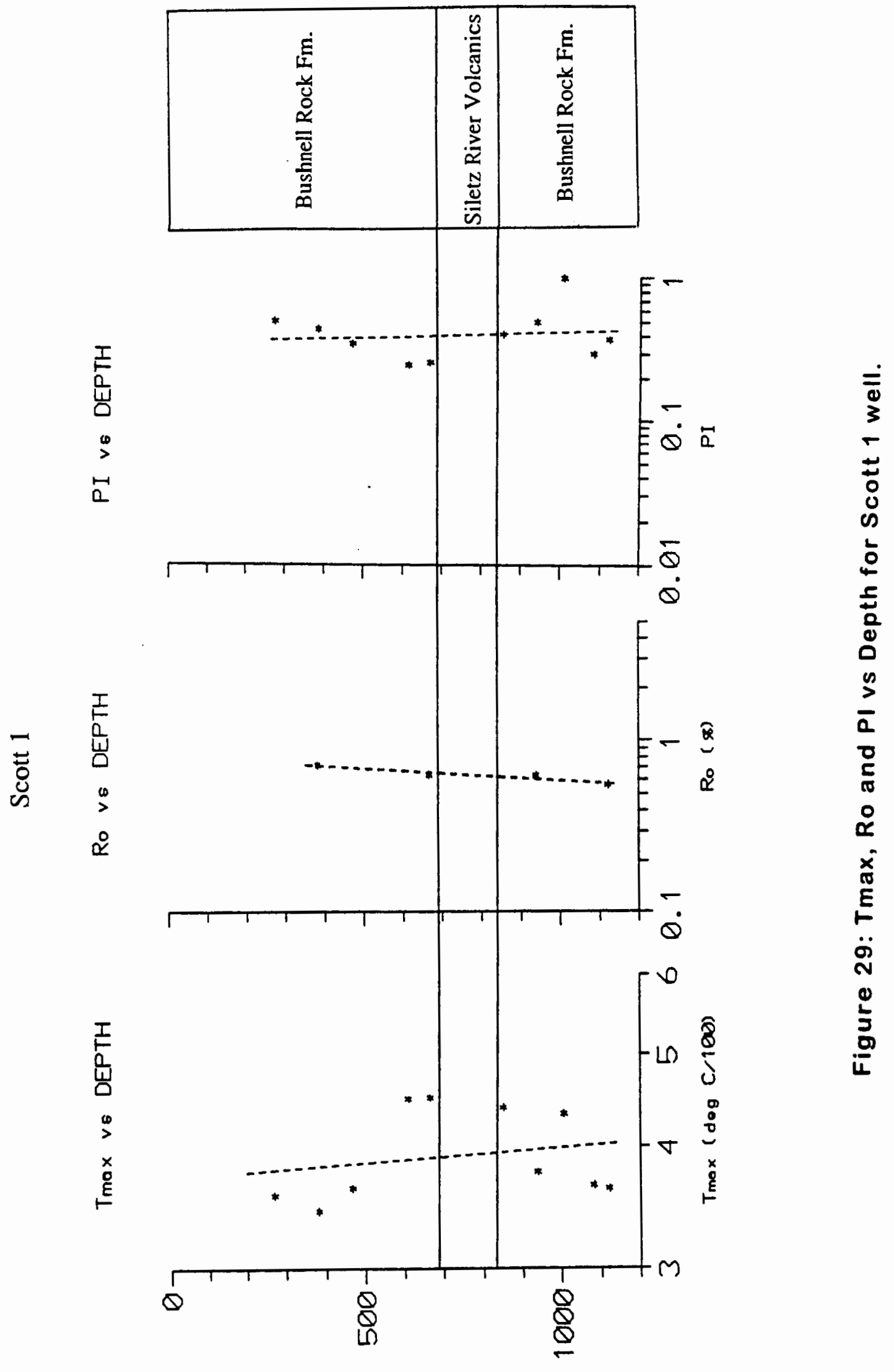

(w) $\mathrm{H \perp d} \exists \mathrm{O}$ 
Ro values, ranging from 0.56 to $0.73 \%$, indicate low maturity (fig. 29). The $t$ test of the correlation of Ro to depth $(r=-0.96)$ indicates that a significant correlation exists, although the indicated gradient is negative. The $t$ test of the slope of the best-fit line indicates that the decrease of Ro with depth is significant. It is possible that the reversal of the expected gradient is due to the thrusting of older sediments over younger ones (Dow, 1977a). Clearly a much larger number of data points would be useful to clarify these results.

Due to the highly variable and unreliable Tmax and PI data for the Scott 1 well, no cross checking of the very limited $(n=4)$ Ro data is possible. The Ro data indicates a level of maturity far too low for any production of gas to have occurred (fig. 25).

The Great Discovery 2 well is in the south-central part of the study area. Tmax values range from 444 to $507^{\circ} \mathrm{C}$, but indicate a reverse correlation, decreasing with depth $(r=-0.77)($ fig. 30$)$. The $t$ tests of the data indicate the correlation is significant and that the slope of the line is also significant. The data indicates a significant decrease of Tmax with depth.

The PI data casts doubt on the Tmax results. PI equals 0.00 to 0.02 for all but one of the samples (fig. 30 ), a result of very low or non-existent $S_{1}$ peaks (Appendix B). Much higher values would be expected, particularly in the upper part of the well, if the Tmax temperatures represented the true state of maturation of the 


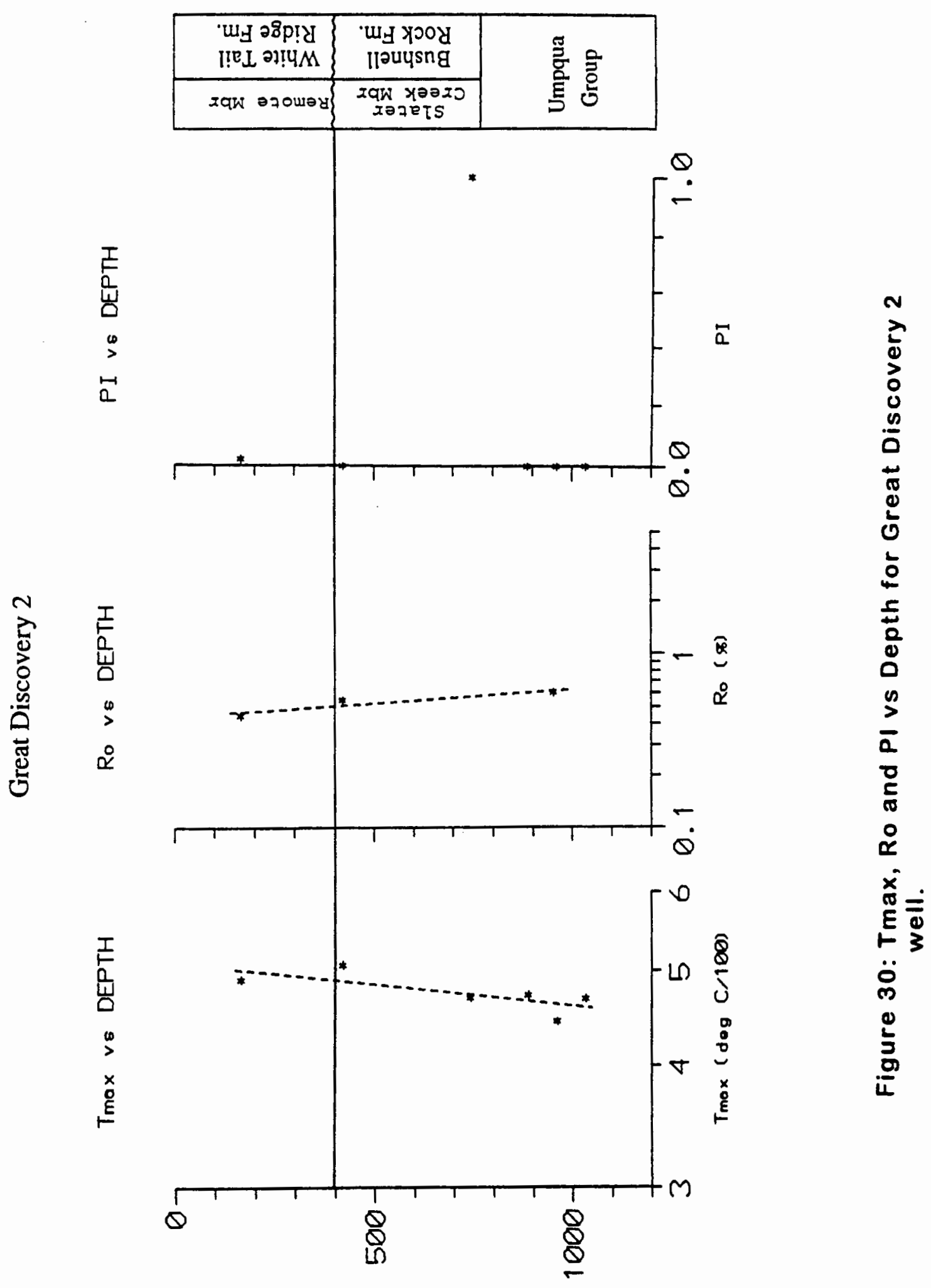

(w) $\mathrm{H} \perp d \exists O$ 
organic matter (compare PI and Tmax scales, fig. 25). The remaining sample calculated to $\mathrm{PI}=1.00$, a completely unreasonable value for a sample with a Tmax of only $469^{\circ} \mathrm{C}$ (fig. 25). Both $S_{1}$ and $S_{2}$ are very low for the sample. All but two of the Tmax results are from samples with less than $0.5 \mathrm{wt} \%$ TOC. Although low TOC is generally expected to lower Tmax temperature, the two samples with higher TOC (fig. 18) have the two lowest Tmax temperatures (fig. 30).

Ro data for the Great Discovery 2 well may be of no value for clarification of this situation. Although $r=0.91$, because of the small number of samples $(n=3)$, the $t$ test of the data indicates no significant correlation between Ro and depth. The means of the Ro and Tmax data were also compared. Ro results range from 0.45 to $0.60 \%$, which corresponds to Tmax temperatures in the range of approximately $425-440^{\circ} \mathrm{C}$ (fig. 25 ), with a mean of $433^{\circ} \mathrm{C}$. The mean of the Tmax data is $475^{\circ} \mathrm{C}$. The $t$ test comparing these means indicates that the difference between them is significant. That is, the Tmax and Ro data do not represent the same level of organic maturation.

TAl data are unavailable for the well due to the difficulty of identifying very small fragments of organic matter, a common problem for microscopists examining Tyee basin samples (D. O'Conner, personal communication, 1994). 
The range of the Great Discovery 2 results represents significant disagreement concerning the maturity of the organic matter in the well. The highest Tmax temperature, $507^{\circ} \mathrm{C}$, at $421 \mathrm{~m}$ (1381 ft) depth, falls well within the dry gas production window, while the lowest Tmax temperature $\left(444^{\circ} \mathrm{C}\right)$, at $961 \mathrm{~m}(3153 \mathrm{ft})$ depth, indicates insufficient maturity for any gas production. Ro and PI data are indicative of a still lower level of maturation.

In the Great Discovery 2 well the Remote Member of the White Tail Ridge Formation is unconformable over the Slater Creek Member of the Bushnell Rock Formation. The Bushnell Rock Formation overlies Umpqua Group undifferentiated mudstones which may be unconformable but are more likely faulted into position (I.-C. Ryu, personal communication, 1994). If the Umpqua Group sediments were thrust beneath the Bushnell Rock Formation late in the history of the basin, it could explain the positioning of lower maturity rocks beneath higher maturity rocks. This would seem to require re-interpretation of the Wildlife Safari Fault, which is now believed to be the underthrust boundary between Umpqua Group sediments and the pre-Tertiary rocks of the Klamath terrane (Ryu and others, 1992) and therefore active early in the history of the basin. Alternatively, a hypothesis of reactivation of movement on the Wildlife Safari Fault late in the history of the basin, as suggested by Niem and Niem (1990) could explain the maturation data. It would be inappropriate to suggest re-interpretation of the 
structural relationships in the basin based on sparse organic geochemical data. The structural relationships in the south and southeastern parts of the basin are important, not only for understanding the tectonic history of the basin, but also for determining its oil and gas potential. If the interpretation of the Wildlife Safari Fault as the underthrust boundary between Umpqua Group and older rocks is correct, then it would be in this area that sediments buried more deeply than any yet drilled might be found.

The Glory Hole 1 well is in the south-central part of the study area, south of the Liles 1 well. Data for this well (fig. 31), from the Tenmile Formation and overlying Berry Creek Member of the White Tail Ridge Formation, are very limited. Tmax results range from 467 to $508^{\circ} \mathrm{C}$, but with only three samples, the $t$ test indicates that no significant correlation between $T$ max and depth has been established. The Ro data $(n=2)$ likewise establishes no correlation. Despite the lack of statistically significant correlations to depth it is still possible to compare the means of the two types of data. Tmax averages $487^{\circ} \mathrm{C}$, while Ro averages $0.54 \%$, which is equivalent to a Tmax value of approximately $431^{\circ} \mathrm{C}$. The $\mathrm{t}$ test comparing these means indicates a significant difference in measured level of maturation by the two methods. The Tmax values indicate that the entire sampled interval is of sufficient maturity for gas production, while Ro data indicates that none of the interval is of sufficient maturity to produce gas. 


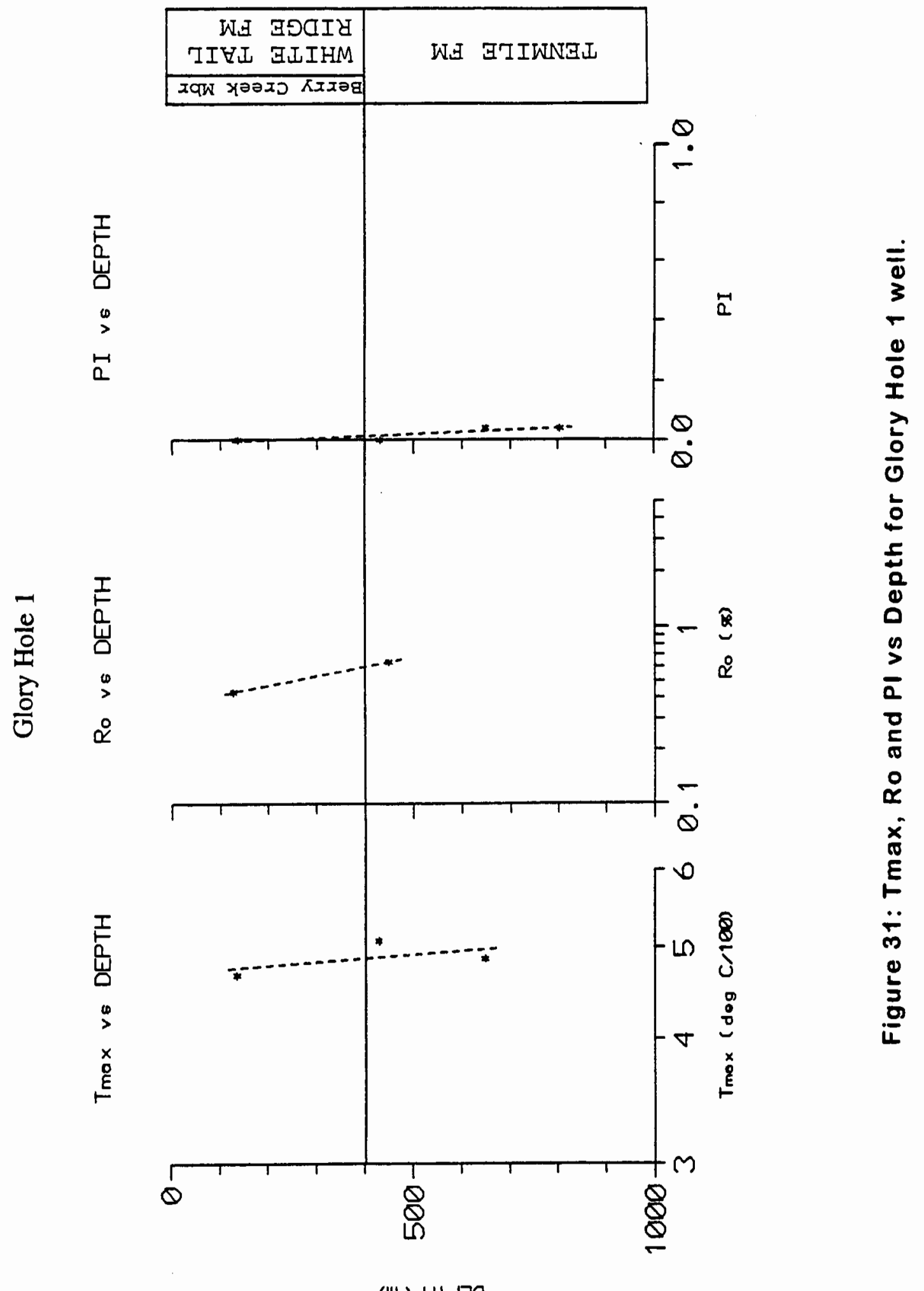


Production index values for Glory Hole 1 are very low due to low or non-existent $S_{1}$ peaks, indicating a low level of maturation. The $t$ test of the correlation coefficient $(r=0.88)$ establishes no significant correlation with depth. The average PI (0.02) corresponds to an Ro value of about $0.2 \%$ and a Tmax of about $405^{\circ} \mathrm{C}$ (fig. 25). The $t$ test comparing mean PI to mean Ro fails to establish a significant difference between the two means.

Tmax data indicates temperatures sufficient for gas production, but Ro and PI do not. None of the types of data establishes a statistically significant relationship between maturation and depth. Thus there is no basis for determining which of these types of data, if any, might be an accurate representation of the level of maturation in the Glory Hole 1 well.

Measured section 7 , in the southwestern portion of the study area, is a composite section and includes surface samples from the Hubbard Creek Member of the Tyee Formation, both the upper and lower members of the Camas Valley Formation, and the Tenmile Formation (fig. 32). The $t$ test of the correlation coefficient ( $r=$ 0.43) for the Tmax data indicates no correlation to elevation has been established. Likewise PI data $(r=0.13)$ shows no correlation to elevation. No Ro data are available for this section. The mean of the Tmax data $\left(435^{\circ} \mathrm{C}\right)$ and the mean of the PI data (0.14) are approximately equal in indicated level of maturation (fig. 25). The $t$ test of the means indicates no significant difference in the levels of 


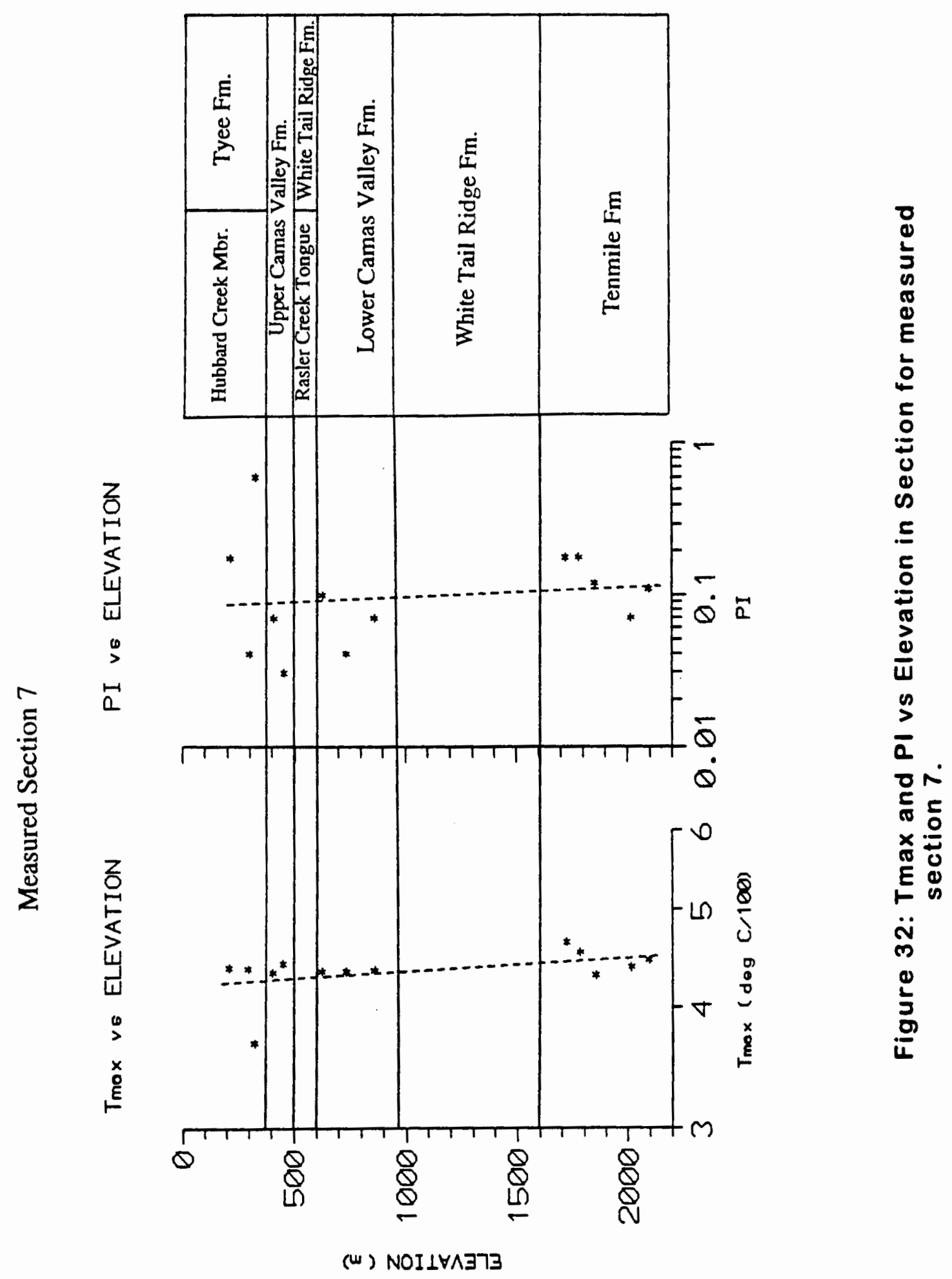


overall maturation of the measured section 7 samples. These values indicate maturation levels well below those needed for gas production.

Three coal samples were analyzed for this study (fig. 33). They are from measured sections 22 , four and six. Section 22 is in the northeastern part of the study area and sections four and six are in the southwest (fig. 2). The t tests of the data show that no correlation with elevation has been established for either Tmax or Ro. It cannot necessarily be expected that samples from widely separated locations will correlate well to elevation when compared in a composite section.

Tmax data for the coal samples indicate a much higher level of maturation than the Ro data. Tmax temperatures are in the 450$468^{\circ} \mathrm{C}$ range, very near the threshold of the dry gas production window, while Ro measurements range from 0.40 to 0.42 percent, which is equivalent to a Tmax temperature of about $420-425^{\circ} \mathrm{C}$. The $t$ test of the means indicates the difference is not random, but rather a significant difference in the maturation level determined by the two techniques.

At the range of temperatures indicated by the Tmax data, just at the threshold of gas production, a small $S_{1}$ peak is usually produced during rock-eval pyrolysis (compare results for other samples, Appendix B). The PI data support the lower maturity interpretation of the Ro data; $P I=0.0$ for all samples. This is due to 

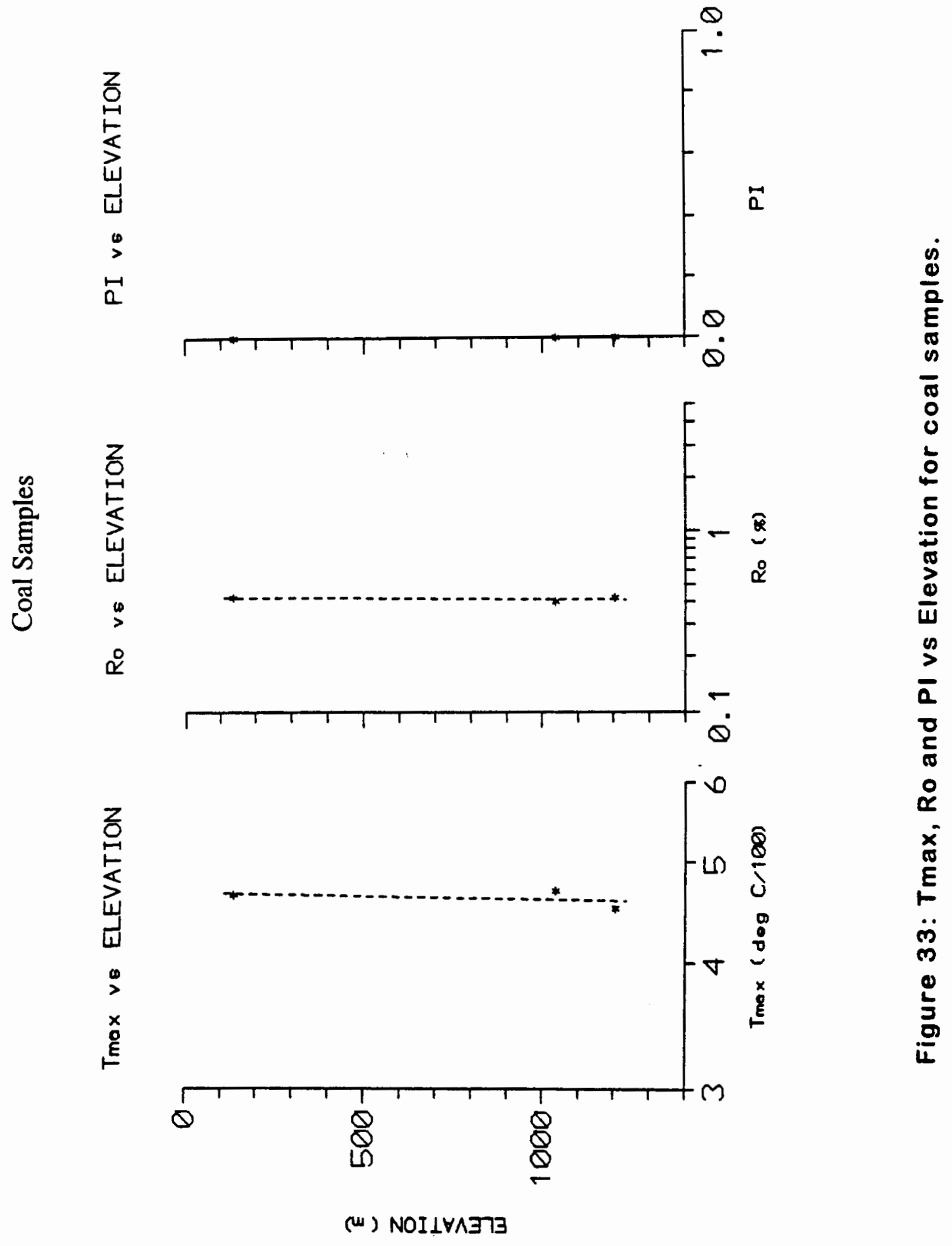
non-existent $S_{1}$ peaks, despite relatively large $S_{2}$ and $S_{3}$ peaks compared to the non-coals. Based on the Ro and PI data these samples are interpreted to be too immature to have entered the dry gas production window.

The maturation data indicate a generally low level of maturity for rocks sampled in this study of the Tyee basin. Liles 1 and Scott 1 were drilled in sediments of too low a maturity for gas production to have occurred. The deepest sedimentary interbed in the volcanics in the lower part of the Long Bell 1 sequence may have reached a high enough maturity for gas production. The thick pile of sediments above the volcanics is immature. Measured section 7 and the coal samples also are of low maturity. Great Discovery 2 and Glory Hole 1 data are too inconclusive for a valid determination to be made.

Wherever PI data are reliable they have very low values, indicating that only very small amounts of oil and gas, if any, have been produced. Nearly the full original capacity to generate hydrocarbons is still contained in the rocks. Unfortunately, based on TOC and HI values, as well as the hydrogen index vs oxygen index plot, this capacity is small.

It is important to remember that several oil and gas shows have been observed in the wells drilled in the basin. In addition, several surface seeps have been reported (Niem and Niem, 1990). These would seem to be indications that some sediments, at least locally, have reached great enough maturity for production of 
hydrocarbons to have occurred. Some of the reports of surface seeps have proven difficult to verify, however, and only one gas sample, from a water well in the southeast part of the basin, has had isotopic analysis. It was found to be biogenic gas (Niem and Niem, 1990).

The maturation data of this study are not particularly encouraging for oil and gas exploration. While the data hold out the possibility that sediments just a little deeper might be in the productive range over a large part of the basin, this in itself is not particularly encouraging since most of the wells in the basin have been drilled through the entire sedimentary section and into the Siletz River Volcanics (Ryu and others, 1992). The subducted oceanic plate model does hold out some hope that deeper sediments that have not yet been encountered may indeed exist in the south and southeastern parts of the basin. Unfortunately, the wells in those areas (Scott 1, Glory Hole 1 and Great Discovery 2) provided the least conclusive of the maturation data.

\section{CONCLUSIONS}

Understanding of the Tyee basin is improving as a result of new mapping and sequence stratigraphic interpretation of the Eocene sedimentary section. These data have been used as an aid in targeting areas for organic geochemical sampling. 
TOC values found in this study are at best fair for source rocks. All mudstone samples classify as either fair or poor source rocks on the basis of TOC (Table 8 ). The low hydrogen index values indicate a very small potential for gas and no oil potential (Table 7). The coals clearly represent much better source rocks than any of the shales or mudstones; it is clear that coals are the richest sources of organic matter found so far in the basin. The question of whether they are abundant enough to produce economic quantities of gas remains unanswered.

The low concentration and poor quality of organic matter in Tyee basin rocks is not particularly encouraging for oil and gas exploration. The fact that nearly all samples plot so consistently in the type III range (classification of Espitalie and others, 1977) indicates a strong, lasting, terrestrial influence on sedimentation in the basin. This terrestrial influence is also an important factor in the low concentration of organic matter. The stratigraphy and lithologies of the basin indicate high rates of sediment influx during much of the history of the basin, resulting in the dilution of organic matter.

The presence of deep-marine mudstones at several levels in the stratigraphic column indicates transgressive periods during which sedimentation rate was reduced. Organic matter in one of the mudstones (Camas Valley Formation) is significantly richer than the average for the Tyee basin samples. 
Maturation indices indicate that most of the basin cannot be expected to contain sedimentary rocks that have matured to the point of producing hydrocarbons. There is a possibility of deeply buried sediments, containing more mature organic matter, in the south and southeastern parts of the basin, based on the tectonic and stratigraphic models.

The Mist gas field in northwest Oregon has produced commercial quantities of gas from a basin with a similar history, and with sediments in the same general range of maturity, as those found here (Armentrout and Suek, 1985; Stormberg, 1991). Thus while the potential for oil or gas production in the Tyee basin is found to be very limited, the results do not preclude the possibility of the discovery of oil or gas in the basin.

Further investigation into the potential of the basin would be reasonable, based on the findings of this study. Additional organic geochemical data from all parts of the basin would be very useful, given the problems of interpreting data from samples with low concentrations of organic matter. Studies to test the tectonic model would certainly be warranted based on the results of this study. More concentrated sampling in the south and southeastern parts of the basin, where data quality was a serious problem in the results presented here, would be of great value. The possibility could be tested that deeper sediments, as yet undrilled, may be of great enough maturity to produce hydrocarbons. More detailed sampling of transgressive deposits could also be used to further 
test the usefulness of the sequence stratigraphic model for finding oil or gas in the basin, and a more detailed examination of the coals in the basin, better defining both their maturity and their extent, would be of great value. 


\section{REFERENCES}

Anderson, E. J., Goodwin, P. W., and Sobieski, T. H., 1984, Episodic accumulation and the origin of formation boundaries in the Helderberg Group of New York State: Geology, v. 12, pp. 120123.

Armentrout, J. M., 1987, Cenozoic stratigraphy, unconformitybounded sequences, and tectonic history of southwestern Washington, in Schuster, J. E., ed., Selected Papers on the Geology of Washington: Washington Division of Geology and Earth Resources, Bulletin 77, pp. 291-320.

Armentrout, J. M., and Franz, U. A., 1983, Tectonic control of Eocene arkosic sediment deposition, Oregon and Washington: American Association of Petroleum Geologists Bulletin, v. 67, pp. 413-414.

Armentrout, J.M., and Suek, D. H., 1985, Hydrocarbon Exploration in Oregon and Washington: American Association of Petroleum Geologists Bulletin, v. 69, no. 4, pp. 627-643.

Atwater, T., 1970, Implications of plate tectonics for the Cenozoic tectonic evolution of western North America: Geological Society of America Bulletin, v. 81, pp. 3513-3536.

Baldwin, E. M., 1965, Geology of the south end of the Oregon Coast Range Tertiary Basin: Northwest Science, v. 39, no. 3, pp. 93103.

Baldwin, E. M., 1974, Eocene stratigraphy of southwestern Oregon:

Oregon Department of Geology and Mineral Industries, Bulletin 83, $40 \mathrm{p}$.

Baldwin, E. M., 1984, The origin of olistostromes in the Roseburg Formation in southwestern Oregon: Oregon Geology, v. 46, pp. 75-76.

Baldwin, E. M., and Perttu, R. K., 1980, Paleogene stratigraphy and structure along the Klamath borderland, Oregon, in Oles, $K$. F., Johnson, J. G., Niem, A. R., and Niem, W. A., eds., Geologic field trips in western Oregon and southwestern Washington: Oregon Department of Geology and Mineral Industries, Bulletin 101, pp. 9-37. 
Barker, C., 1982, Organic geochemistry in petroleum exploration: American Association of Petroleum Geologists, Education Course Note Series 10, $151 \mathrm{p}$.

Bird, K. J., 1967, Biostratigraphy of the Tyee Formation (Eocene), southwest Oregon: Ph.D. dissertation, University of Wisconsin, Madison, 209 p.

Black, G. L., 1990, Geologic map of the Reston Quadrangle, Douglas County, Oregon: Oregon Department of Geology and Mineral Industries Geologic Map Series GMS-68, scale 1:24,000.

Black, G. L., 1993, Geologic map of the Camas Valley Quadrangle, Douglas and Coos Counties, Oregon: Oregon Department of Geology and Mineral Industries Geologic Map Series GMS-76, scale 1:24,000.

Blackwell, D. D., and Steele, J. L., 1989, Thermal Conductivity of Sedimentary Rocks: Measurement and Significance, in Naeser, N. D., and McCulloh, T. H., eds., Thermal History of Sedimentary Basins: Springer-Verlag, New York, pp. 13-37.

Brown, L. F., Jr., and Fisher, W. L., 1977, Seismic Stratigraphic Interpretation of Depositional Systems: Examples from Brazilian Rift and Pull-Apart Basins, in Payton, C. E., ed., Seismic Stratigraphy - Applications to Hydrocarbon Exploration: American Association of Petroleum Geologists, Memoir 26, pp. 53-62.

Browning, J. L., and Flanagan, T., 1980, Source rock study of the lower Tertiary formations of southwestern Oregon: Consultants' report, 96 p.

Buckovic, W. A., 1979, The Eocene deltaic system of west-central Washington, in Armentrout, J. M., Cole, M. R., and Terbest, H., Jr., eds., Cenozoic Paleogeography of the Western United States, Pacific Coast Paleogeography Symposium 3: Society of Economic Paleontologists and Mineralogists, Pacific Section, pp. 147-163.

Burns, L. K., and Ethridge, F., 1979, Petrology and diagenetic effects of lithic sandstone: Paleocene and Eocene Umpqua Formation, southwest Oregon, in Scholle, P. A., and Schluger, P. R., eds., Aspects of Diagenesis: Society of Economic Paleontologists and Mineralogists, Special Publication No. 26, pp. 307-317.

Chan, M. A., 1982, Comparison of sedimentology and diagenesis of Eocene rocks, southwest Oregon: Ph.D. dissertation, University of Wisconsin, Madison, $322 \mathrm{p}$. 
Chan, M. A., 1985, Correlations of diagenesis with sedimentary facies in Eocene sandstones, western Oregon: Journal of Sedimentary Petrology, v. 55, no. 3, pp. 322-333.

Chan, M. A., and Dott, R. H., Jr., 1983, Shelf and deep-sea sedimentation in Eocene fore-arc basin, western Oregon - fan or non-fan?: American Association of Petroleum Geologists Bulletin, v. 67, pp. 2100-2116.

Creaney, S., and Passey, Q. R., 1993, Recurring Patterns of Total Organic Carbon and Source Rock Quality within a Sequence Stratigraphic Framework: American Association of Petroleum Geologists Bulletin, v. 77, pp. 386-401.

Davis, R. A., Jr., 1983, Depositional Systems: A Genetic Approach to Sedimentary Geology: Prentice-Hall, Englewood Cliffs, New Jersey, $669 \mathrm{p}$.

Demaison, G., and Bourgeois, F. T., 1984, Environment of deposition of middle Miocene (Alcanar) carbonate source beds, Casablanca field, Tarragona basin, offshore Spain, in Palacas, J. G., ed., Petroleum Geochemistry and Source Rock Potential of Carbonate Rocks: American Association of Petroleum Geologists, Studies in Geology 18, pp. 151-162.

Dembicki, H., Jr., Horsfield, B., and Ho, T. T. Y., 1983, Source Rock Evaluation by Pyrolysis-Gas Chromatography: American Association of Petroleum Geologists Bulletin, v. 67, pp. 10941103.

DGSI, unpubl., A Profile of DGSI (lab manual): DGSI Labs, The Woodlands, Texas.

Diller, J. S., 1898, Roseburg folio, Oregon: U. S. Geological Survey, Geologic Atlas of U. S., Folio No. 49.

Dott, R. H., Jr., and Bird, K. J., 1979, Sand transport through channels across an Eocene shelf and slope in southwestern Oregon, U. S. A., in Doyle, L. J., and Pilkey, O. H., eds., Geology of continental slopes: Society of Economic Paleontologists and Mineralogists, Special Publication No. 27, pp. 327-342.

Dow, W. G., unpubl., Lab report No. DGSI/94/2941: DGSI, The Woodlands, TX.

Dow, W. G., 1977a, Kerogen studies and geological interpretations: Journal of Geochemical Exploration, v. 7, pp. 79-99. 
Dow, W. G., 1977b, Petroleum Source Beds on Continental Slopes and Rises: American Association of Petroleum Geologists Bulletin, v. 62, pp. 1584-1606.

Dow, W. G., and O'Conner, D. I., 1982, Kerogen Maturity and Type by Reflected Light Microscopy Applied to Petroleum Exploration, in Staplin, R. P., Dow, W. G., Milner, C. W. D., O'Conner, D. I., Pocock, S. A. J., van Gijzel, P., Welte, D. H., and Yukler, M. A., How to assess maturation and paleotemperatures: Society of Economic Paleontologists and Mineralogists, Short Course No. 7, pp. 1-27.

Duckworth, W. E., 1968, Statistical Techniques in Technological Research: An Aid to Research Productivity: Methuen and Co., London, $303 \mathrm{p}$.

Duncan, R. A., 1982, A captured island chain in the Coast Range of Oregon and Washington: Journal of Geophysical Research, $v$. 87, pp. 10827-10837.

Engel, M., and Macko, S. A., eds., 1993, Organic Geochemistry: Principles and Applications: Topics in Geobiology, v. 11: Plenum Press, New York, 861 p.

Espitalie, J., Laporte, J. L., Madec, M., Marquis, F., Leplat, P., Paulet, J., and Boutefeu, A., 1977, Rapid method for source rock characterization and for evaluating their petroleum potential and their degree of evolution (English translation): Institut Francais Du Petrole, v. 32, pp. 23-42.

Galloway, W. F., 1974, Deposition and Diagenetic Alteration of Sandstone in Northeast Pacific Arc-Related Basins: Implications for Graywacke Genesis: Geological Society of America Bulletin, v. 85, pp. 379-390.

Geochem Laboratories, Inc., 1980, Source rock evaluation reference manual, p. E-7.

Heller, P. L., 1983, Sedimentary response to Eocene tectonic rotation in western Oregon: Ph.D. dissertation, University of Arizona, Tucson, $343 \mathrm{p}$.

Heller, P. L., and Dickinson, W. R., 1985, Submarine ramp facies model for delta-fed, sand-rich turbidite systems: American Association of Petroleum Geologists Bulletin, v. 69, pp. 960976.

Heller, P. L., and Ryberg, P. T., 1983, Sedimentary record of subduction to fore-arc transition in the rotated Eocene basin of western Oregon: Geology, v. 11, pp. 380-383. 
Hinch, H. H., 1980, The Nature of Shales and the Dynamics of Hydrocarbon Expulsion in the Gulf Coast Tertiary Section, in Roberts, W. H., III, and Cordell, R. J., eds., Problems of Petroleum Migration: American Association of Petroleum Geologists, Studies in Geology No. 10, pp. 1-18.

Hunt, J. M., 1972, Distribution of Carbon in the Crust of the Earth: American Association of Petroleum Geologists Bulletin, v. 56, pp. 2273-2277.

Hunt, J. M., 1977, Distribution of Carbon as Hydrocarbons and Asphaltic Compounds in Sedimentary Rocks: American Association of Petroleum Geologists Bulletin, v. 61, pp. 100104.

Hunt, J. M., 1979, Petroleum Geochemistry and Geology: W. E. Freeman and Co., San Francisco, $617 \mathrm{p}$.

Koch, G. S., Jr., and Link, R. F., 1970, Statistical Analysis of Geological Data: Wiley and Sons, New York, $375 \mathrm{p}$.

Law, B. E., Anders, D. E., Fouch, T. D., Pawlewicz, M. J., Lickus, M. R., and Molenaar, C. M., 1984, Petroleum source rock evaluations of outcrop samples from Oregon and southern California: Oregon Geology, v. 46, no. 7, pp. 77-81.

Lesher, C. E., 1914, The Eden Ridge Coal Field, Coos County, Oregon: U. S. Geological Survey, Bulletin 541, pp. 399-418.

Loutit, T. S., Hardenbol, J., Vail, P. R., and Baum, G. R., 1988, Condensed sections: the key to age determination and correlation of continental margin sequences, in Wilgus, C. W., Hastings, B. S., Kendall, C. G. C., Posamentier, H. W., Ross, C. A., and Van Wagoner, J. C., eds., Sea-Level Changes: An Integrated Approach: Society of Economic Paleontologists and Mineralogists, Special Publication 42, pp. 109-154.

Lovell, J.P. B., 1969, Tyee Formation: undeformed turbidites and their lateral equivalents: mineralogy and paleogeography: Geological Society of America Bulletin, v. 80, pp. 9-22.

McKeel, D. R., 1972, Systematics, biostratigraphy and paleoceanography of Tertiary planktonic foraminiferal stages, Oregon Coast Range: M.S. thesis, University of California, Davis, $117 \mathrm{p}$. 
Miles, G. A., 1977, Planktonic foraminifera of the lower Tertiary Roseburg, Lookingglass, and Flournoy Formations, southwest Oregon: Ph.D. dissertation, University of Oregon, Eugene, 374 p.

Milner, C. W. D., 1982, Geochemical analyses of sedimentary organic matter and interpretation of maturation and source potential, in Staplin, R. P., Dow, W. G., Milner, C. W. D., O'Conner, D. I., Pocock, S. A. J., van Gijzel, P., Welte, D. H., and Yukler, M. A., How to assess maturation and paleotemperatures: Society of Economic Paleontologists and Mineralogists, Short Course No. 7, pp. 217-52.

Molenaar, C. M., 1985, Depositional relations of Umpqua and Tyee Formations (Eocene), southwestern Oregon: American Association of Petroleum Geologists Bulletin, v. 69, pp. 1217 1229.

Newton, V. C., Jr., 1980, Prospects for oil and gas in the Coos Basin, western Coos, Douglas and Lane counties, Oregon: Oregon Department of Geology and Mineral Industries, Oil and Gas Investigation 6, $74 \mathrm{p}$.

Niem, A. R., and Niem, W. A., 1984, Cenozoic geology and geologic history of western Oregon, in Kulm, L. D., Peterson, C. P., Connard, G. G., Johnson, S. Y., Niem, W. A., McClain, K. J., Loubere, P. W., Lewis, B. T. R., Couch, R. W., Niem, A. R., Scheidegger, K. F., Crosson, R. S., and Stewart, R. J., eds., Western North American continental margin and adjacent ocean floor off Oregon and Washington: Marine Science International, Ocean Margin Drilling Program, Regional Atlas Series, Atlas 1, Sheet 17.

Niem, A. R., and Niem, W. A., 1990, Geology and oil, gas, and coal resources, southern Tyee Basin, southern Coast Range, Oregon: Oregon Department of Geology and Mineral Industries, Open File Report 0-89-3, 43 p.

Olmstead, D. L., 1989, Hydrocarbon Exploration and Occurrences in Oregon: Oregon Department of Geology and Mineral Industries, Oil and Gas Investigation 15, 78 p.

Perttu, R. K., 1976, Structural Geology of the Northeast Quarter of the Dutchman Butte Quadrangle, Oregon: M. S. thesis, Portland State University, $60 \mathrm{p}$.

Perttu, R. K., and Benson, G. T., 1980, Deposition and deformation of the Eocene Umpqua Group, Sutherlin area, southwestern Oregon: Oregon Geology, v. 42, no. 8, pp. 135-140. 
Peters, K. E., 1986, Guidelines for Evaluating Petroleum Source Rock Using Programmed Pyrolysis: American Association of Petroleum Geologists Bulletin, v. 70, pp. 318-329.

Posamentier, H. W., Jervey, M. T., and Vail, P. R., 1988, Eustatic Controls on Clastic Deposition I - Conceptual Framework, in Wilgus, C. W., Hastings, B. S., Kendall, C. G. C., Posamentier, H. W., Ross, C. A., and Van Wagoner, J. C., eds., Sea-Level Changes: An Integrated Approach: Society of Economic Paleontologists and Mineralogists, Special Publication 42, pp. 109-124.

Posamentier, H. W., and Vail, P. R., 1988, Eustatic Controls on Clastic Deposition II - Conceptual Framework, in Wilgus, C. W., Hastings, B. S., Kendall, C. G. C., Posamentier, H. W., Ross, C. A., and Van Wagoner, J. C., eds., Sea-Level Changes: An Integrated Approach: Society of Economic Paleontologists and Mineralogists, Special Publication 42, pp. 124-154.

Powell, T. G., Creaney, S., and Snowden, L. R., 1982, Limitations of use of organic petrographic techniques for identification of petroleum source rocks: American Association of Petroleum Geologists Bulletin, v. 66, pp. 420-435.

Robert, P., 1988, Organic Metamorphism and Geothermal History: Microscopic Study of Organic Matter and Thermal Evolution of Sedimentary Basins (Translation of Robert, P., 1985, Histoire geothermique et diagenese organique: Elf-Aquitaine): D. Reidel Publishing Co., Boston, $311 \mathrm{p}$.

Roure, F., Carayon, V., and Rangib, C., 1986, Evolution des bassins franciscains de California, de l'Oregon, et de basse Californie (Etats-Unis et Mexique): Geological Society of France Bulletin, v. 11, pp. 931-944.

Ryberg, P. T., 1984, Sedimentation, structure and tectonics of the Umpqua Group (Paleocene to early Eocene), southwestern Oregon: Ph.D. dissertation, University of Arizona, Tucson, 422 p.

Ryberg, P. T., 1989, Paleogene to early Eocene depositional systems along a tectonically active continental margin, southwestern Oregon (abstract): Geological Society of America, Abstracts with Programs, v. 21, no. 5, p. 137.

Ryu, I.-C., unpubl., Stratigraphy, sedimentology, and hydrocarbon potential of the early to middle Eocene forearc and subduction zone strata in the southern Tyee Basin, southern Oregon Coast Range: Ph.D. thesis proposal, Oregon State University, Corvallis. 
Ryu, I.-C., and Niem, A. R., 1993, Sequence Stratigraphy in Active Convergent Margins: Eocene Tyee Basin, Southern Oregon Coast Range (abstract): American Association of Petroleum Geologists, Annual Convention Program, pp. 175-176.

Ryu, I.-C., Niem, A. R., and Niem, W. A., 1992, Geologic Interpretation of the Schematic Fence Diagram of the Southern Tyee Basin, Oregon Coast Range: Oregon Department of Geology and Mineral Industries, Oil and Gas Investigation 18, $28 \mathrm{p}$.

Sloss, L. L., 1963, Sequences in the cratonic interior of North America: Geological Society of America Bulletin, v. 74, pp. 93114.

Sloss, L. L., 1988, Forty Years of Sequence Stratigraphy: Geological Society of America Bulletin, v. 100, pp. 1661-1665.

Snavely, P. D., Jr., 1984, Sixty million years of growth along the Oregon continental margin, in Clarke, S. H., ed., U.S. Geological Survey, Highlights in Marine Research: U.S. Geological Survey, Circular 938, pp. 9-18.

Snavely, P. D., Jr., Wagner, H. C., and Lander, D. H., 1980, Interpretation of the Cenozoic geologic history, central Oregon continental margin: Geological Society of America Bulletin, v. 91, pp. 143-146.

Snavely, P. D., Jr., Wagner, H. C., and McLeod, N. S., 1964, Rhythmic-bedded eugeosynclinal deposits of the Tyee Formation, Oregon Coast Range, in Merriam, D. F., ed., Symposium on cyclic sedimentation: Kansas Geological Survey Bulletin, v. 169, pp. 461-480.

Stormberg, G. J., 1991, The Mist Gas Field, N. W. Oregon: Source Rock Characterization and Stable Isotope (C,H,N) Geochemistry: M. S. Thesis, Oregon State University, Corvallis, $164 \mathrm{p}$.

Sweeney, J. J., and Burnham, A. K., 1990, Evaluation of a Simple Model of Vitrinite Reflectance Based on Chemical Kinetics: American Association of Petroleum Geologists Bulletin, v. 74, pp. 1559-1570.

Thoms, R. E., 1965, Biostratigraphy of the Umpqua Formation, southwest Oregon: Ph.D. dissertation, University of California, Berkeley, $219 \mathrm{p}$. 
Tissot, B., Durand, B., Espitalie, J., and Combaz, A., 1974, Influence of Nature and Diagenesis of Organic Matter in Formation of Petroleum: American Association of Petroleum Geologists Bulletin, v. 58. pp. 499-506.

Tissot, B. P., Pelet, R., and Ungerer, P., 1987, Thermal History of Sedimentary Basins, Maturation Indices, and Kinetics of Oil and Gas Generation: American Association of Petroleum Geologists Bulletin, v. 71, pp. 1445-1466.

Tissot, B. P., and Welte, D. H., 1984, Petroleum formation and occurrence, Second Edition: Springer-Verlag, Berlin, 699 p.

Vail, P. R., Mitchum, R. M., and Thompson, S., III, 1977, Seismic stratigraphy and global changes of sea level, part 3: relative changes of sea level from coastal onlap, in Payton, C. W., ed., Seismic Stratigraphy Applications to Hydrocarbon Exploration: American Association of Petroleum Geologists, Memoir 26, pp. 63-97.

van Gijzel, P., 1982, Characterization and identification of kerogen and bitumen and determination of thermal maturation by means of qualitative and quantitative microscopical techniques, in Staplin, R. P., Dow, W. G., Milner, C. W. D., O'Conner, D. I., Pocock, S. A. J., van Gijzel, P., Welte, D. H., and Yukler, M. A., How to assess maturation and paleotemperatures: Society of Economic Paleontologists and Mineralogists, Short Course No. 7, pp. 217-52.

Van Krevelen, D. W., 1961, Coal: Elsevier, Amsterdam, 514 p.

Van Wagoner, J. C., Posamentier, H. W., Mitchum, R. M., Vail, P. R., Sarg, J. F., Loutit, T. S., and Hardenbol, J., 1988, An overview of sequence stratigraphy and key definitions, in Wilgus, C. W., Hastings, B. S., Kendall, C. G. C., Posamentier, H. W., Ross, C. A., and Van Wagoner, J. C., eds., Sea-Level Changes: An Integrated Approach: Society of Economic Paleontologists and Mineralogists, Special Publication 42, pp. 39-45.

Van Wagoner, J. C., Mitchum, R. M., Campion, K. M., and Rahmanian, V. D., 1990, Siliciclastic Sequence Stratigraphy in Well Logs, Cores, and Outcrops: Concepts for High-Resolution Correlation of Time and Facies: American Association of Petroleum Geologists, Methods in Exploration Series No. 7, 55 p.

Waples, D. W., 1981, Organic Geochemistry for Exploration Geologists: Burgess Publishing, Minneapolis, $151 \mathrm{p}$. 
Waples, D. W., 1985, Geochemistry in Petroleum Exploration: International Human Resources Development Corporation, Boston, 232 p.

Weatherby, D. G., 1991, Stratigraphy and sedimentology of the late Eocene Bateman Formation, southern Oregon Coast Range: $M$. S. thesis, University of Oregon, Eugene, $161 \mathrm{p}$.

Weimer, R. J., 1984, Relations of unconformities, tectonics, and sea level changes, Cretaceous of western interior U.S. A., in Schlee, J.S., ed., Interregional Unconformities and Hydrocarbon Accumulation: American Association of Petroleum Geologists, Memoir 36, pp. 7-35.

Wells, R. E., Engebretson, D. C., Snavely, P. D., and Coe, R. S., 1984, Cenozoic plate motions and the volcano-tectonic evolution of western Oregon and Washington: Tectonics, v. 3, pp. 275-294.

Wignall, P. B., 1991, Model for transgressive black shales?: Geology, v. 19, pp. 167-170.

Wignall, P. B., and Maynard, J. R., 1993, The Sequence Stratigraphy of Transgressive Black Shales, in Katz, B. J., and Pratt, L. M., eds., Source Rocks in a Sequence Stratigraphic Framework: American Association of Petroleum Geologists, Studies in Geology 37, pp. 35-47.

Wilson, J. L., 1975, Carbonate Facies in Geologic History: SpringerVerlag, New York, $471 \mathrm{p}$. 


\section{APPENDICES}


APPENDIX A

LITHOLOGY

TOTAL ORGANIC CARBON (TOC) 


\section{LITHOLOGY AND TOC DATA - WELL SAMPLES}

\begin{tabular}{|c|c|c|c|c|c|c|c|c|}
\hline $\begin{array}{l}\text { WELL } \\
\text { NO. }\end{array}$ & \multirow{2}{*}{$\begin{array}{l}\text { L WELL } \\
\text { NAME } \\
\text { ong Bell } 1\end{array}$} & \multirow{2}{*}{$\begin{array}{l}\text { SAMPLE } \\
\text { NO. } \\
\text { LB } 4500\end{array}$} & \multirow{2}{*}{$\begin{array}{l}\text { LAB } \\
\text { DGSI }\end{array}$} & \multicolumn{2}{|c|}{$\begin{array}{c}\text { DEPTH } \\
(\mathrm{ft}) \quad(\mathrm{m})\end{array}$} & \multirow{2}{*}{$\begin{array}{l}\text { FORMATION } \\
\text { Or MEMBER } \\
\text { Umpqua undif. }\end{array}$} & \multirow{2}{*}{$\begin{array}{l}\text { LITHOLOGY } \\
\text { mudstone, carbonaceous }\end{array}$} & \multirow{2}{*}{$\begin{array}{l}\text { TOC } \\
(w t \%) \\
0.34\end{array}$} \\
\hline 1 & & & & 4500 & 1373 & & & \\
\hline 1 & Long Bell 1 & LB4800 & DGSI & 4800 & 1464 & Umpqua undif. & mudstone, carbonaceous & 0.31 \\
\hline 1 & Long Bell 1 & LB5100 & DGSI & 5100 & 1556 & Umpqua undif. & mudstone, carbonaceous & 0.35 \\
\hline 1 & Long Befl 1 & LB 5400 & DGS I & 5400 & 1647 & Umpqua undif. & mudstone, silty ss interbeds & 0.48 \\
\hline 1 & Long Bell 1 & LB 5700 & DGSI & 5700 & 1739 & Umpqua undif. & mudstone, laminated & 0.36 \\
\hline 1 & Long Bell 1 & LB6060 & DGSI & 6060 & 1848 & Umpqua undif. & mudstone, massive & 0.60 \\
\hline 1 & Long Bell 1 & LB6320 & DGSI & 6320 & 1928 & Umpqua undif. & mudstone, a/a & 0.72 \\
\hline 1 & Long Bell 1 & LB6580 & DGSI & 6580 & 2007 & Umpqua undif. & mudstone, ala & 0.65 \\
\hline 1 & Long Bell 1 & LB6900 & DGSI & 6900 & 2105 & Umpqua undif. & mudstone, a/a & 0.73 \\
\hline 1 & Long Bell 1 & LB 7260 & DGSI & 7260 & 2214 & Umpqua undif. & mudstone, tuff., carbonaceous & 0.49 \\
\hline 1 & Long Bell 1 & LB7540 & DGSI & 7540 & 2300 & Umpqua undif. & mudstone, tuff. red, gry, grn & 0.38 \\
\hline 1 & Long Bell 1 & LB 7840 & DGS I & 7840 & 2391 & Umpqua undif. & mudstone, ala & 0.19 \\
\hline 1 & Long Bell 1 & LB8080 & DGSI & 8080 & 2464 & Umpqua undif. & mudstone, tuff., laminated & 0.19 \\
\hline 1 & Long Bell 1 & LB8380 & DGSI & 8380 & 2556 & Umpqua undif. & mudstone, tuff., red-brn, gry & 0.26 \\
\hline 8 & Liles 1 & L900 & DGSI & 900 & 275 & Umpqua undif. & mudstone, silty streaks & 0.54 \\
\hline 8 & Liles 1 & L1480 & DGSI & 1480 & 451 & Umpqua undif. & mudstone, a/a & 0.68 \\
\hline 8 & Liles 1 & L1780 & DGSI & 1780 & 543 & Umpqua undif. & mudstone, a/a & 0.58 \\
\hline 8 & Liles 1 & $L 2500$ & DGSI & 2500 & 763 & Umpqua undif. & mudstone, ala & 0.61 \\
\hline 8 & Liles 1 & L3060 & DGSI & 3060 & 933 & Umpqua undif. & mudstone, a/a & 0.68 \\
\hline 8 & Liles 1 & L3540 & DGSI & $\mathbf{3 5 4 0}$ & 1080 & Umpqua undif. & mudstone, ala & 0.57 \\
\hline 8 & Liles 1 & $L 4140$ & DGSI & 4140 & 1263 & Umpqua undif. & mudstone, ala & 0.64 \\
\hline 8 & Liles 1 & L4580 & DGSI & 4580 & 1397 & Umpqua undif. & mudstone, a/a & 0.64 \\
\hline 8 & Liles 1 & L5140 & DGSI & 5140 & 1568 & Umpqua undif & mudstone, ala & 0.73 \\
\hline $\mathbf{B}$ & Liles 1 & $\mathbf{L 5 5 0 0}$ & DGSI & 5500 & 1678 & Umpqua undif. & mudstone, drk gry poorly cmntd & 0.64 \\
\hline 8 & Liles 1 & $\mathbf{L} 5920$ & DGSI & 5920 & 1806 & Umpqua undif. & mudstone, a/a & 0.66 \\
\hline 8 & Liles 1 & $L 6240$ & DGSI & 6240 & 1903 & Umpqua undif. & mudstone, drk gry, well cmntd & 0.64 \\
\hline 8 & Liles 1 & L6540 & DGSI & 6540 & 1995 & Umpqua undif. & mudstone, silty laminations & 0.67 \\
\hline 8 & Liles 1 & L6960 & DGSI & 6960 & 2123 & Umpqua undif. & mudstone, a/a & 0.60 \\
\hline 10 & $S \operatorname{cott} 1$ & S885 & DGS I & 885 & 270 & Bushnell Rk. & conglomerate & 0.24 \\
\hline 10 & $S \operatorname{cott} 1$ & $\mathbf{S 1 2 5 0}$ & DGSI & 1250 & $\mathbf{3 8 1}$ & Bushnell Rk. & conglomerate & 0.48 \\
\hline 10 & Scott 1 & S1535 & DGSI & 1535 & 468 & Bushnell Rk. & conglomerate & 0.48 \\
\hline 10 & $S \operatorname{cott} 1$ & 52000 & DGSI & 2000 & 610 & Bushnell Rk. & conglomerate & 0.44 \\
\hline 10 & $5 \operatorname{cott} 1$ & 52180 & DGSI & 2180 & 665 & Bushnell Rk. & conglomerate & 0.57 \\
\hline 10 & $s \operatorname{cott} 1$ & $\$ 2790$ & DGSI & 2790 & 851 & Bushnell Rk. & conglomerate & 0.37 \\
\hline
\end{tabular}




\section{LITHOLOGY AND TOC DATA - WELL SAMPLES (CONT.)}

\begin{tabular}{|c|c|c|c|c|c|c|c|c|}
\hline $\begin{array}{l}\text { WELL } \\
\text { NO. }\end{array}$ & $\begin{array}{l}\text { L WELL } \\
\text { NAME }\end{array}$ & $\begin{array}{l}\text { SAMPLE } \\
\text { NO. }\end{array}$ & LAB & $\begin{array}{c}\text { DEP } \\
(\mathrm{ft})\end{array}$ & $\begin{array}{l}\text { TH } \\
(m)\end{array}$ & $\begin{array}{l}\text { FORMATION } \\
\text { Or MEMBER }\end{array}$ & LITHOLOGY & $\begin{array}{l}\text { TOC } \\
(w t \%)\end{array}$ \\
\hline 10 & $s \operatorname{cott} 1$ & 53080 & DGSI & 3080 & 939 & Bushnell Rk. & conglomerate & 0.29 \\
\hline 10 & $s \operatorname{cott} 1$ & 53300 & DGSI & 3300 & 1007 & Bushnell Rk. & conglomerate & 0.06 \\
\hline 10 & scott 1 & $\$ 3550$ & DGSI & 3550 & 1083 & Bushnell Rk. & conglomerate & 0.26 \\
\hline 10 & scott 1 & $\$ 3680$ & DGSI & 3680 & 1122 & Bushnett Rk. & conglomerate & 0.31 \\
\hline 17 & $\begin{array}{l}\text { Great } \\
\text { Disc. } 2\end{array}$ & 51-009 & USGS & 540 & 165 & Remote Mbr. & mudstone & 0.36 \\
\hline 17 & $\begin{array}{l}\text { Great } \\
\text { Disc. } 2\end{array}$ & 51.010 & USGS & 1380 & 421 & Slater Ck. & mudstone & 0.47 \\
\hline 17 & $\begin{array}{l}\text { Great } \\
\text { Disc. } 2\end{array}$ & 51-011 & USGS & 2430 & 741 & Slater Ck. & mudstone & 0.34 \\
\hline 17 & $\begin{array}{l}\text { Great } \\
\text { Disc. } 2\end{array}$ & $51-012$ & USGS & 2910 & 888 & $\begin{array}{l}\text { Umpqua } \\
\text { undif. }\end{array}$ & mudstone & 0.44 \\
\hline 17 & $\begin{array}{l}\text { Great } \\
\text { Disc. } 2\end{array}$ & 51.013 & USGS & 3150 & 961 & $\begin{array}{l}\text { Umpqua } \\
\text { undif. }\end{array}$ & mudstone & 0.69 \\
\hline 17 & $\begin{array}{l}\text { Great } \\
\text { Disc. } 2\end{array}$ & $51-014$ & USGS & $\mathbf{3 3 9 0}$ & 1034 & $\begin{array}{l}\text { Umpqua } \\
\text { undif. }\end{array}$ & mudstone & 0.70 \\
\hline 9 & $\begin{array}{l}\text { Glory } \\
\text { Hole } 1\end{array}$ & $51-015$ & USGS & 450 & 137 & Berry Ck. & mudstone & 0.65 \\
\hline 9 & $\begin{array}{l}\text { Glory } \\
\text { Hole } 1\end{array}$ & $51-016$ & USGS & 1410 & 430 & Tenmile Fm. & mudstone & 0.55 \\
\hline 9 & $\begin{array}{l}\text { Glory } \\
\text { Hole } 1\end{array}$ & $51-017$ & USGS & 2130 & 650 & Tenmile Fm. & mudstone & 0.56 \\
\hline 9 & $\begin{array}{l}\text { Glory } \\
\text { Hole } 1\end{array}$ & $51-018$ & USGS & 2640 & 805 & Tenmile Fm. & mudstone & 0.94 \\
\hline
\end{tabular}




\section{LITHOLOGY AND TOC DATA - OUTCROP SAMPLES}

\begin{tabular}{|c|c|c|c|c|c|c|c|c|}
\hline $\begin{array}{l}\text { SEC } \\
\text { NO. }\end{array}$ & $\begin{array}{l}\text { SECTION } \\
\text { NAME }\end{array}$ & SAMPLE NO. & LAB & $\begin{array}{c}\text { DISTAN } \\
\text { TOP OF } \\
\text { (ft) }\end{array}$ & $\begin{array}{l}\text { CE FROM } \\
\text { SECTION } \\
\text { (m) }\end{array}$ & $\begin{array}{l}\text { FORMATION } \\
\text { Or MEMBER }\end{array}$ & LITHOLOGY & $\begin{array}{l}\text { TOC } \\
(w t \%)\end{array}$ \\
\hline 7 & Sandy Creek* & RN-91-399 & DGSI & 703 & 214 & Hubbard Creek & mudstone & 0.44 \\
\hline 7 & Sandy Creek* & RN-91-398 & DGSI & 985 & 300 & Hubbard Croek & mudstone & 0.76 \\
\hline 7 & Remote & $R N-91-255$ & DGSI & 1077 & 328 & Hubbard Creek & mudstone & 0.06 \\
\hline 7 & Remote & RN-91-396 & DGSI & 1341 & 409 & Upper Camas V. & mudstone & 0.74 \\
\hline 7 & Remote & RN-91-253 & DGSI & 1506 & 454 & Upper Camas V. & mudstone & 0.82 \\
\hline 7 & Remote & $R N-91-180$ & DGSI & 2053 & 626 & Camas Valley & mudstone & 0.41 \\
\hline 7 & Remote & RN-91-179 & DGSI & 409 & 735 & Camas Valley & mudstone & 0.51 \\
\hline 7 & Remote & $R N-91-178$ & DGSI & 2829 & 863 & Camas Valley & mudstone & 0.46 \\
\hline 7 & Remote & $R N-91-243$ & DGSI & 5648 & 1723 & Tenmile & mudstone & 0.57 \\
\hline 7 & Remote & RN-91-244 & DGS I & 5849 & 1784 & Tenmile & mudstone & 0.55 \\
\hline 7 & Remote & $R N-91-245$ & DGSI & 6086 & 1856 & Tenmile & mudstone & 0.34 \\
\hline 7 & Remote & $R N-91-258$ & DGSI & 6606 & 2015 & Tenmile & mudstone & 0.72 \\
\hline 7 & Remote & $R N-91-248$ & DGSI & 6871 & 2096 & Tenmile & mudstone & 0.67 \\
\hline 22 & $1-5$ & $R-92-027$ & USGS & 450 & 137 & Spencer Fm. & coal & 34.26 \\
\hline 4 & Sand Rk. Mtn. & $R-92-017$ & USGS & 3950 & 1205 & Remote Mbr. & shaly coal & 9.74 \\
\hline 6 & Rasler Ck. & $R N-91-270$ & USGS & 3400 & 1037 & Remote Mbr. & coal & 45.58 \\
\hline
\end{tabular}

\footnotetext{
* Upper portion of composite section 7.
} 


\section{APPENDIX B}

ROCK-EVAL PYROLYSIS DATA 


\section{ROCK-EVAL PYROLYSIS DATA - WELL SAMPLES}

WELL WELL SAMPLE LAB DEPTH S1 S2 S3 Tmax S1I HI OI S2/S3 PI NO. NAME NO.

(ft) (m) $(\mathrm{mg} / \mathrm{g})(\mathrm{mg} / \mathrm{g})(\mathrm{mg} / \mathrm{g})\left({ }^{\circ} \mathrm{C}\right)$ TOC

\begin{tabular}{|c|c|c|c|c|c|c|c|c|c|c|c|c|c|c|}
\hline 1 & Long Bell 1 & LB 4500 & DGSI & 4500 & 1373 & 0.03 & 0.11 & 0.33 & 427 & 9 & 32 & 97 & 0.33 & 0.21 \\
\hline 1 & Long Bell 1 & LB 4800 & DGSI & 4800 & 1464 & 0.03 & 0.09 & 0.24 & 431 & 10 & 29 & 77 & 0.38 & 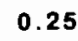 \\
\hline 1 & Long Bell 1 & LB5100 & DGSI & 5100 & 1556 & 0.04 & 0.16 & 0.29 & 398 & 11 & 46 & 83 & 0.55 & 0.20 \\
\hline 1 & Long Bell 1 & LB5400 & DGSI & 5400 & 1647 & 0.03 & 0.17 & 0.28 & 432 & 6 & 35 & 58 & 0.61 & \\
\hline 1 & Long Bell 1 & LB5700 & DGSI & 5700 & 1739 & 0.04 & 0.15 & 0.25 & 437 & 11 & 42 & 69 & 0.60 & 0.2 \\
\hline 1 & Long Bell 1 & LB6060 & DGSI & 6060 & 1848 & 0.06 & 0.24 & 0.20 & 465 & 10 & 40 & 33 & 1.20 & $\mathbf{0}$ \\
\hline 1 & Long Belf 1 & LB6320 & DGSI & 6320 & 1928 & 0.06 & 0.34 & 0.31 & 441 & 8 & 47 & 43 & 1.10 & 0.15 \\
\hline 1 & Long Bell 1 & LB6580 & DGSI & 6580 & 2007 & 0.04 & 0.29 & 0.29 & 448 & 6 & 45 & 45 & 1.00 & 0.1 \\
\hline 1 & Long Bell 1 & LB6900 & DGSI & 6900 & 2105 & 0.08 & 0.35 & 0.56 & 445 & 11 & 48 & 77 & 0.63 & .19 \\
\hline 1 & Long Bell 1 & LB7260 & DGSI & 7260 & 2214 & 0.08 & 0.19 & 0.58 & 453 & 16 & 39 & 118 & 0.33 & 0.30 \\
\hline 1 & Long Bell 1 & LB 7540 & DGSI & 7540 & 2300 & 0.04 & 0.15 & 0.20 & 390 & 11 & 39 & 53 & 0.75 & 0 . \\
\hline 1 & Long Bell 1 & LB7840 & DGSI & 7840 & 2391 & 0.06 & 0.08 & 0.20 & 425 & 32 & 42 & 105 & 0.40 & 0.4 \\
\hline 1 & Long Bell 1 & LB8080 & DGSI & 8080 & 2464 & 0.03 & 0.06 & 0.17 & 305 & 16 & 32 & 89 & 0.35 & 0.3 \\
\hline 1 & Long Bell 1 & LB8380 & DGSI & 8380 & 2556 & 0.03 & 0.08 & 0.13 & 339 & 12 & 31 & 50 & 0.62 & 0.27 \\
\hline 8 & Liles 1 & L900 & DGSI & 900 & 275 & 0.05 & 0.22 & 0.18 & 425 & 9 & 41 & 33 & 1.22 & 9 \\
\hline 8 & Liles 1 & L1480 & DGSI & 1480 & 451 & 0.04 & 0.26 & 0.26 & 442 & 6 & 38 & 38 & 1.00 & 0.1 \\
\hline 8 & Liles 1 & $L 1780$ & DGSI & 1780 & 543 & 0.03 & 0.26 & 0.08 & 445 & 5 & 45 & 14 & 3.25 & 0.1 \\
\hline 8 & Liles 1 & L2500 & DGSI & 2500 & 763 & 0.07 & 0.27 & 0.12 & 438 & 11 & 44 & 20 & 2.25 & 0.2 \\
\hline 8 & Liles 1 & L3060 & DGSI & 3060 & 933 & 0.07 & 0.28 & 0.23 & 454 & 10 & 41 & 34 & 1.22 & 0.20 \\
\hline 8 & Liles 1 & L3540 & DGSI & 3540 & 1080 & 0.05 & 0.16 & 0.22 & 432 & 9 & 28 & 39 & 0.73 & \\
\hline 8 & Liles 1 & L4140 & DGSI & 4140 & 1263 & 0.05 & 0.25 & 0.12 & 457 & 8 & 39 & 19 & 2.08 & 0.1 \\
\hline 8 & Liles 1 & L4580 & DGSI & 4580 & 1397 & 0.09 & 0.30 & 0.20 & 450 & 14 & 47 & 31 & 1.50 & 0.23 \\
\hline 8 & Liles 1 & L5140 & GSI & 5140 & 1568 & 0.07 & 0.33 & 0.16 & 442 & 10 & 45 & 22 & 2.06 & 0.18 \\
\hline 8 & Liles 1 & L5500 & DGSI & 5500 & 1678 & 0.07 & 0.29 & 0.14 & 444 & 11 & 45 & 22 & 2.07 & 0.19 \\
\hline 8 & Liles 1 & L5920 & DGSI & 5920 & 1806 & 0.07 & 0.30 & 0.20 & 451 & 11 & 45 & 30 & 1.50 & 0.19 \\
\hline 8 & Liles 1 & L6240 & DGSI & 6240 & 1903 & 0.08 & 0.29 & 0.29 & 442 & 13 & 45 & 45 & 1.00 & 0.22 \\
\hline 8 & Liles 1 & L6540 & DGSI & 6540 & 1995 & 0.09 & 0.35 & 0.37 & 448 & 13 & 52 & 55 & 0.95 & 0.20 \\
\hline 8 & Liles 1 & L6960 & DGSI & 6960 & 2123 & 0.12 & 0.29 & 0.39 & 452 & 20 & 48 & 65 & 0.74 & 0.29 \\
\hline 0 & $S \operatorname{cott} 1$ & 5885 & DGSI & 885 & 270 & 0.13 & 0.13 & 0.15 & 356 & 54 & 54 & 63 & 0.87 & 0.50 \\
\hline 0 & $S \operatorname{cott} 1$ & S1250 & DGSI & 1250 & 381 & 0.14 & 0.18 & 0.14 & 343 & 29 & 38 & 29 & 1.29 & 0.44 \\
\hline 0 & $S \operatorname{cott} 1$ & $\$ 1535$ & DGSI & 1535 & 468 & 0.17 & 0.31 & 0.17 & 362 & 35 & 65 & 35 & 1.82 & 0.35 \\
\hline & $S \operatorname{cott} 1$ & 52000 & DGSI & 2000 & 610 & 0.06 & 0.18 & 0.04 & 450 & 14 & 41 & 9 & 4.50 & 0.25 \\
\hline 0 & Scott 1 & 52180 & DGSI & 2180 & 665 & 0.10 & 0.29 & 0.10 & 451 & 18 & 51 & 18 & 2.90 & 0.26 \\
\hline & Scott 1 & 52790 & DGSI & 2790 & 851 & 0.11 & 0.16 & 0.15 & 440 & 30 & 43 & 41 & 1.07 & \\
\hline
\end{tabular}




\section{ROCK-EVAL PYROLYSIS DATA - WELL SAMPLES (CONT.)}

\begin{tabular}{|c|c|c|c|c|c|c|c|c|c|c|c|c|c|c|}
\hline $\begin{array}{l}\text { WEL } \\
\text { NO. }\end{array}$ & $\begin{array}{l}\text { LL WELL } \\
\text { NAME }\end{array}$ & $\begin{array}{l}\text { SAMPLE } \\
\text { NO. }\end{array}$ & LAB & $\underset{(f t)}{\text { DEP }}$ & $\begin{array}{l}\text { PTH } \\
(m)\end{array}$ & $\begin{array}{l}\mathrm{s1} \\
(\mathrm{mg} / \mathrm{g})\end{array}$ & $\begin{array}{c}\mathrm{S2} \\
(\mathrm{mg} / \mathrm{g})\end{array}$ & $\begin{array}{c}\mathbf{s 3} \\
(\mathbf{m g} / g)\end{array}$ & $\begin{array}{l}T \max \\
\left({ }^{\circ} \mathrm{C}\right)\end{array}$ & $\begin{array}{l}\text { StI } \\
\text { TOC }\end{array}$ & HI & 01 & $52 / 53$ & PI \\
\hline 10 & scott 1 & S3080 & DGSI & 3080 & 939 & 0.10 & 0.10 & 0.06 & 376 & 34 & 34 & 21 & 1.67 & 0.50 \\
\hline 10 & $s \operatorname{cott} 1$ & S3300 & DGSI & 3300 & 1007 & 0.03 & 0.00 & 0.08 & 433 & 50 & 0 & 133 & 0.00 & 1.00 \\
\hline 10 & $S \operatorname{cott} 1$ & $\mathbf{S 3 5 5 0}$ & DGSI & 3550 & 1083 & 0.03 & 0.07 & 0.05 & 364 & 12 & 27 & 19 & 1.40 & 0.30 \\
\hline 10 & $S \operatorname{cott} 1$ & S3680 & DGSI & 3680 & 1122 & 0.09 & 0.15 & 0.06 & 361 & 29 & 48 & 19 & 2.50 & 0.38 \\
\hline 17 & $\begin{array}{l}\text { Great } \\
\text { Disc. } 2\end{array}$ & 51-009 & USGS & 540 & 165 & 0.01 & 0.44 & 0.41 & 490 & 3 & 122 & 113 & 1.07 & 0.02 \\
\hline 17 & $\begin{array}{l}\text { Great } \\
\text { Disc. } 2\end{array}$ & 51.010 & USGS & 1380 & 421 & 0.00 & 1.63 & 0.53 & 507 & 0 & 346 & 112 & 3.07 & 0.00 \\
\hline 17 & $\begin{array}{l}\text { Great } \\
\text { Disc. } 2\end{array}$ & 51.011 & USGS & 2430 & 741 & 0.02 & 0.01 & 0.53 & 469 & 6 & 2 & 155 & 0.01 & 1.00 \\
\hline 17 & $\begin{array}{l}\text { Great } \\
\text { Disc. } 2\end{array}$ & $51-012$ & USGS & 2910 & 888 & 0.00 & 0.10 & 0.85 & 472 & 0 & 22 & 193 & 0.11 & 0.00 \\
\hline 17 & $\begin{array}{l}\text { Great } \\
\text { Disc. } 2\end{array}$ & $51-013$ & USGS & 3150 & 961 & 0.00 & 0.29 & 0.66 & 444 & 0 & 42 & 95 & 0.43 & 0.00 \\
\hline 17 & $\begin{array}{l}\text { Great } \\
\text { Disc. } 2\end{array}$ & 51-014 & USGS & 3390 & 1034 & 0.00 & 0.19 & 0.86 & 468 & 0 & 27 & 122 & 0.22 & 0.00 \\
\hline 9 & $\begin{array}{l}\text { Glory } \\
\text { Hole } 1\end{array}$ & 51-015 & USGS & 450 & 137 & 0.01 & 0.50 & 1.41 & 467 & 2 & 76 & 216 & 0.35 & 0.00 \\
\hline 9 & $\begin{array}{l}\text { Glory } \\
\text { Hole } 1\end{array}$ & $51-016$ & USGS & 1410 & 430 & 0.00 & 0.29 & 0.82 & 508 & 0 & 52 & 149 & 0.35 & 0.00 \\
\hline 9 & $\begin{array}{l}\text { Glory } \\
\text { Hole } 1\end{array}$ & $51-017$ & USGS & 2130 & 650 & 0.01 & 0.26 & 0.69 & 486 & 2 & 46 & 123 & 0.37 & 0.04 \\
\hline 9 & $\begin{array}{l}\text { Glory } \\
\text { Hole } 1\end{array}$ & 51-018 & USGS & 2640 & 805 & 0.03 & 0.75 & 2.63 & NR & 3 & 79 & 279 & 0.28 & 0.04 \\
\hline
\end{tabular}


ROCK-EVAL PYROLYSIS DATA - OUTCROP SAMPLES

\begin{tabular}{|c|c|c|c|c|c|c|c|c|c|c|c|c|c|c|}
\hline $\begin{array}{l}\text { SEC } \\
\text { NO. }\end{array}$ & $\begin{array}{l}\text { C. SECTIO } \\
\text {. NAME }\end{array}$ & $\begin{array}{l}\text { ON SAMPLE } \\
\text { NO. }\end{array}$ & $\begin{array}{l}\text { LAB DI } \\
\text { TO }\end{array}$ & $\begin{array}{l}\text { STANC } \\
\text { P OF S } \\
(f t)\end{array}$ & $\begin{array}{l}\text { CE FROM } \\
\text { SECTION } \\
\text { (m) }\end{array}$ & $\begin{array}{c}\mathrm{s1} \\
\text { (mg/g }\end{array}$ & $\begin{array}{c}52 \\
/ g)(m g / g\end{array}$ & $\begin{array}{c}\text { S3 } \\
(\mathrm{g})(\mathrm{mg} / \mathrm{g})\end{array}$ & $\begin{array}{l}\operatorname{Tmax} \\
\left({ }^{\circ} \mathrm{C}\right)\end{array}$ & $\begin{array}{l}\text { S1I } \\
\text { TOC }\end{array}$ & $\mathrm{HI}$ & 01 & $52 / 53$ & PI \\
\hline 7 & $\begin{array}{l}\text { Sandy } \\
\text { Creek* }\end{array}$ & RN-91-399 & DGSI & 703 & 214 & 0.02 & 0.09 & 0.07 & 438 & 5 & 20 & 16 & 1.29 & 0.18 \\
\hline 7 & $\begin{array}{l}\text { Sandy } \\
\text { Creek* }\end{array}$ & RN-91-398 & DGSI & 985 & 300 & 0.02 & 0.43 & 0.07 & 437 & 3 & 57 & 9 & 6.14 & 0.04 \\
\hline 7 & Remote & RN-91-255 & DGSI & 1077 & 328 & 0.03 & 0.02 & 0.00 & 369 & 50 & 33 & 0 & 0.00 & 0.60 \\
\hline 7 & Remote & RN-91-396 & DGSI & 1341 & 409 & 0.03 & 0.38 & 0.10 & 433 & 4 & 51 & 14 & 3.80 & 0.07 \\
\hline 7 & Remote & $R N-91-253$ & DGSI & 1506 & 454 & 0.01 & 0.30 & 0.28 & 442 & 1 & 37 & 32 & 1.15 & 0.03 \\
\hline 7 & Remote & $R N-91-180$ & DGSI & 2053 & 626 & 0.03 & 0.28 & 0.09 & 434 & 7 & 68 & 22 & 3.11 & 0.10 \\
\hline 7 & Remote & $R N-91.179$ & DGSI & 2409 & 735 & 0.01 & 0.25 & 0.08 & 434 & 2 & 49 & 16 & 3.13 & 0.04 \\
\hline 7 & Remote & $R N-91-178$ & DGSI & 2829 & 863 & 0.01 & 0.13 & 0.04 & 435 & 2 & 28 & 9 & 3.25 & 0.07 \\
\hline 7 & Remote & RN-91-243 & DGSI & 5648 & 1723 & 0.04 & 0.18 & 0.06 & 464 & 7 & 32 & 11 & 3.00 & 0.18 \\
\hline 7 & Remote & $R N-91-244$ & DGSI & 5849 & 1784 & 0.03 & 0.14 & 0.09 & 453 & 5 & 25 & 16 & 1.56 & 0.18 \\
\hline 7 & Remote & $R N-91-245$ & DGSI & 6086 & 1856 & 0.02 & 0.15 & 0.05 & 430 & 6 & 44 & 15 & 3.00 & 0.12 \\
\hline 7 & Remote & $R N-91-258$ & DGSI & 6606 & 2015 & 0.02 & 0.25 & 0.05 & 438 & 3 & 35 & 7 & 5.00 & 0.07 \\
\hline 7 & Remote & $R N-91-248$ & DGSI & 6871 & 2096 & 0.02 & 0.16 & 0.05 & 445 & 3 & 24 & 7 & 3.20 & 0.11 \\
\hline 22 & 1.5 & $R-92-027$ & USGS & 450 & 137 & 0.00 & 32.30 & 11.38 & 463 & 0 & 94 & 33 & 2.83 & 0.00 \\
\hline 4 & $\begin{array}{l}\text { Sand } \\
\text { Rk. Mtn. }\end{array}$ & $R-92-017$ & USGS & 3950 & 1205 & 0.00 & 5.21 & 4.78 & 450 & 0 & 53 & 49 & 1.08 & 0.00 \\
\hline 6 & $\begin{array}{l}\text { Rasler } \\
\text { Creek }\end{array}$ & RN-91-270 & USGS & 3400 & 1037 & 0.00 & 80.00 & 7.16 & 468 & 0 & 175 & 15 & 11.17 & 0.00 \\
\hline
\end{tabular}




\author{
APPENDIX C \\ VITRINITE REFLECTANCE (RO) \\ THERMAL ALTERATION INDEX (TAI) \\ VISUAL ASSESSMENT SUMMARY
}


WELL WELL SAMPLE LAB NO. NAME NO.$$
\text { (1) }
$$

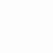

\section{Long Bell 16045}

\section{Long Bell 16160}

\section{Long Bell 16571}

\section{Long Bell 16820}

8 Liles $1 \quad L 900$

8 Liles $1 \quad$ L4140

8 Liles $1 \quad$ L5140

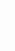

8

8

$(10$

10

10

10

1

17

17

8 Liles $1 \quad$ L6240

8 Liles $1 \quad$ L6960

$10 S \operatorname{cott} 1 \quad \$ 1250$

10 Scott $1 \quad S 2180$

$10 s \operatorname{cott} 1 \quad s 3080$

10 scott $1 \quad S 3680$

17 Great GD540 DGSI $540 \quad 165 \quad 0.45 \quad$ ND

\section{Great GD1380 DGSI $1380 \quad 421 \quad 0.55 \quad$ ND}

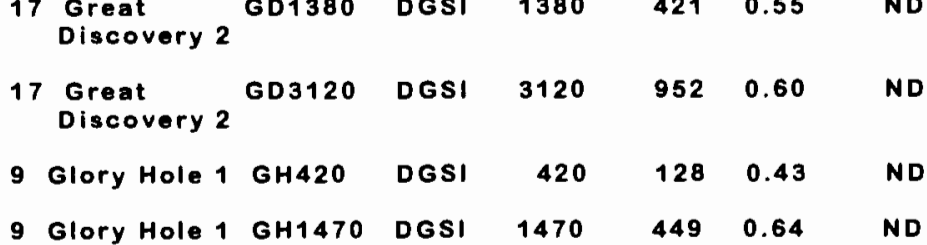

\section{Long Bell 13720
1 Long Bell 14702}

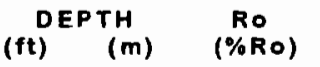

TAI

Organic Matter Type (\%) vitrinite $/$ inertinite $/$ lipids

\begin{tabular}{|c|c|c|}
\hline 40 & 30 & 30 \\
\hline 60 & 20 & 20 \\
\hline ND & ND & ND \\
\hline ND & ND & ND \\
\hline ND & ND & ND \\
\hline ND & ND & ND \\
\hline ND & ND & ND \\
\hline ND & ND & ND \\
\hline ND & ND & ND \\
\hline ND & ND & ND \\
\hline ND & ND & ND \\
\hline ND & ND & ND \\
\hline ND & ND & ND \\
\hline ND & ND & ND \\
\hline ND & ND & ND \\
\hline ND & ND & ND \\
\hline ND & ND & ND \\
\hline 55 & 10 & 35 \\
\hline 45 & 10 & 45 \\
\hline 50 & 10 & 40 \\
\hline 55 & 10 & 35 \\
\hline 65 & 20 & 15 \\
\hline 50 & 20 & 30 \\
\hline 50 & 20 & 30 \\
\hline 50 & 10 & 40 \\
\hline 45 & 20 & 35 \\
\hline$M$ & $M$ & $\mathbf{T}$ \\
\hline 50 & 20 & 30 \\
\hline 30 & 10 & 60 \\
\hline 65 & 10 & 25 \\
\hline 75 & 20 & 5 \\
\hline
\end{tabular}




\section{SUMMARY Of RO, TAI, VISUAL ASSESSMENT DATA - OUTCROP SAMPLES}

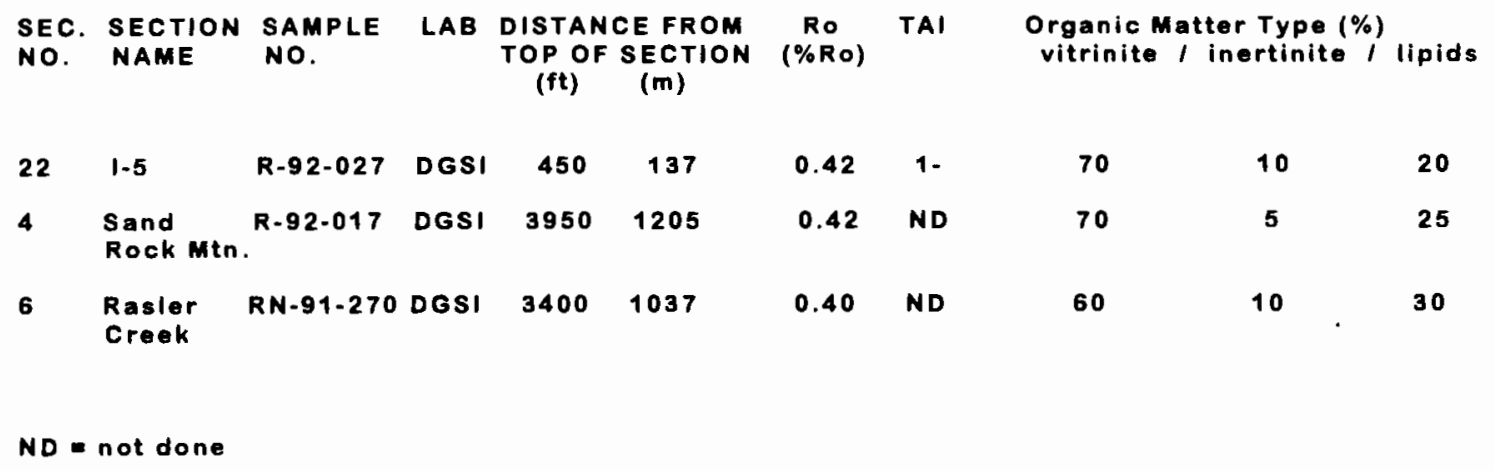


APPENDIX D

VITRINITE REFLECTANCE HISTOGRAMS 


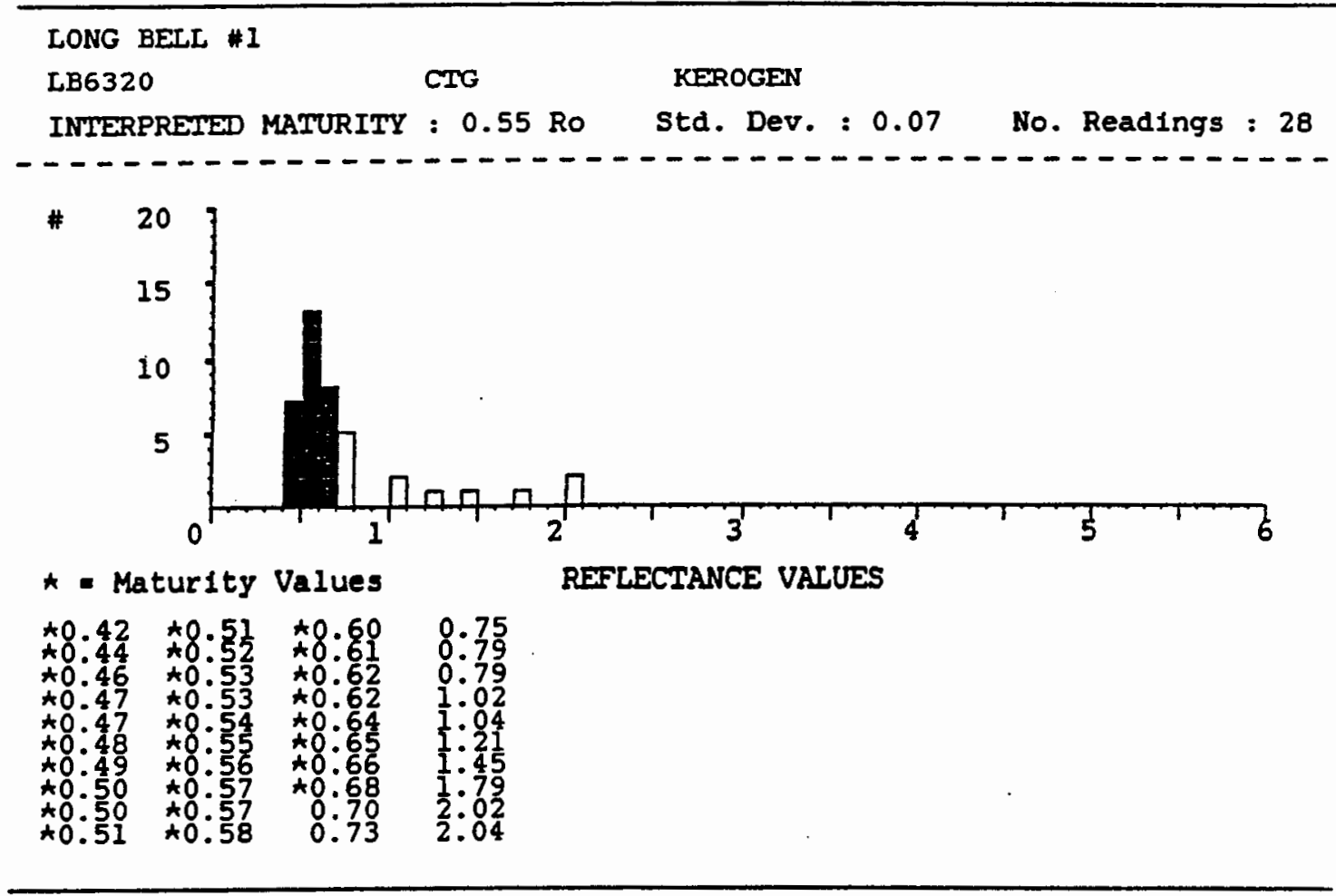

LONG BELL \#I

LB6900 CTG KEROGEN

INTERPRETED MATURITY : 0.55 Ro std. Dev. : 0.07 No. Readings : 26
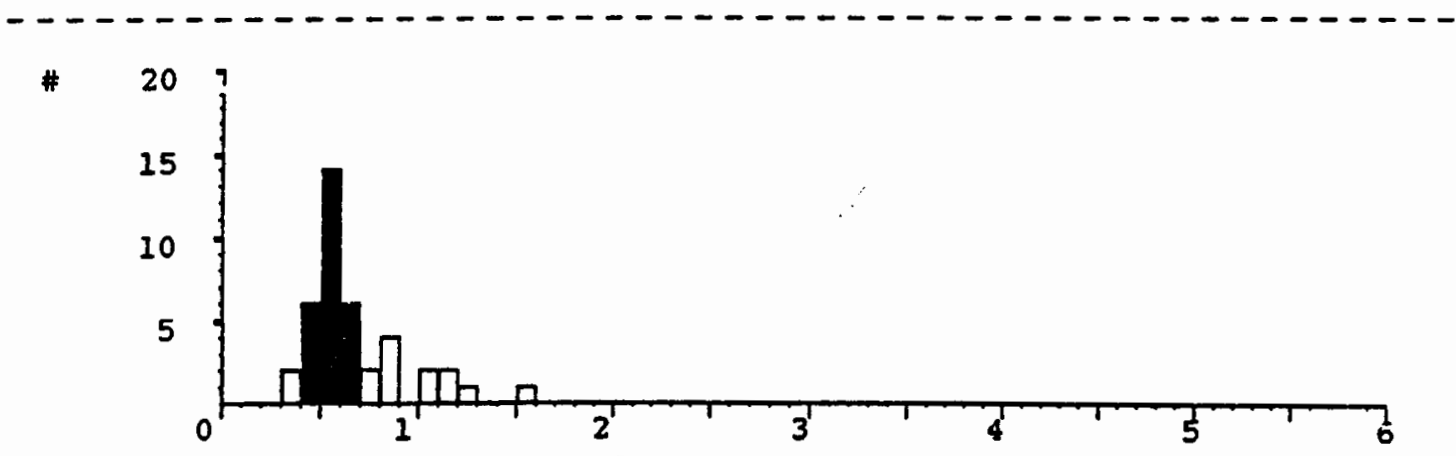

$\star$ = Maturity Values

REFLECTANCE VALUES

$\begin{array}{rrrr}0.36 & \star 0.52 & \star 0.58 & 0.82 \\ \star 0.36 & \star 0.53 & \star 0.59 & 0.82 \\ \star 0.42 & \star 0.54 & \star 0.60 & 0.85 \\ \star 0.43 & \star 0.54 & \star 0.62 & 0.89 \\ \star 0.44 & \star 0.54 & \star 0.63 & 1.08 \\ \star 0.45 & \star 0.55 & \star 0.64 & 1.08 \\ \star 0.48 & \star 0.57 & \star 0.65 & 1.12 \\ \star 0.49 & \star 0.57 & \star 0.67 & 1.18 \\ \star 0.51 & \star 0.57 & 0.74 & 1.26 \\ \star 0.52 & \star 0.58 & 0.77 & 1.58\end{array}$




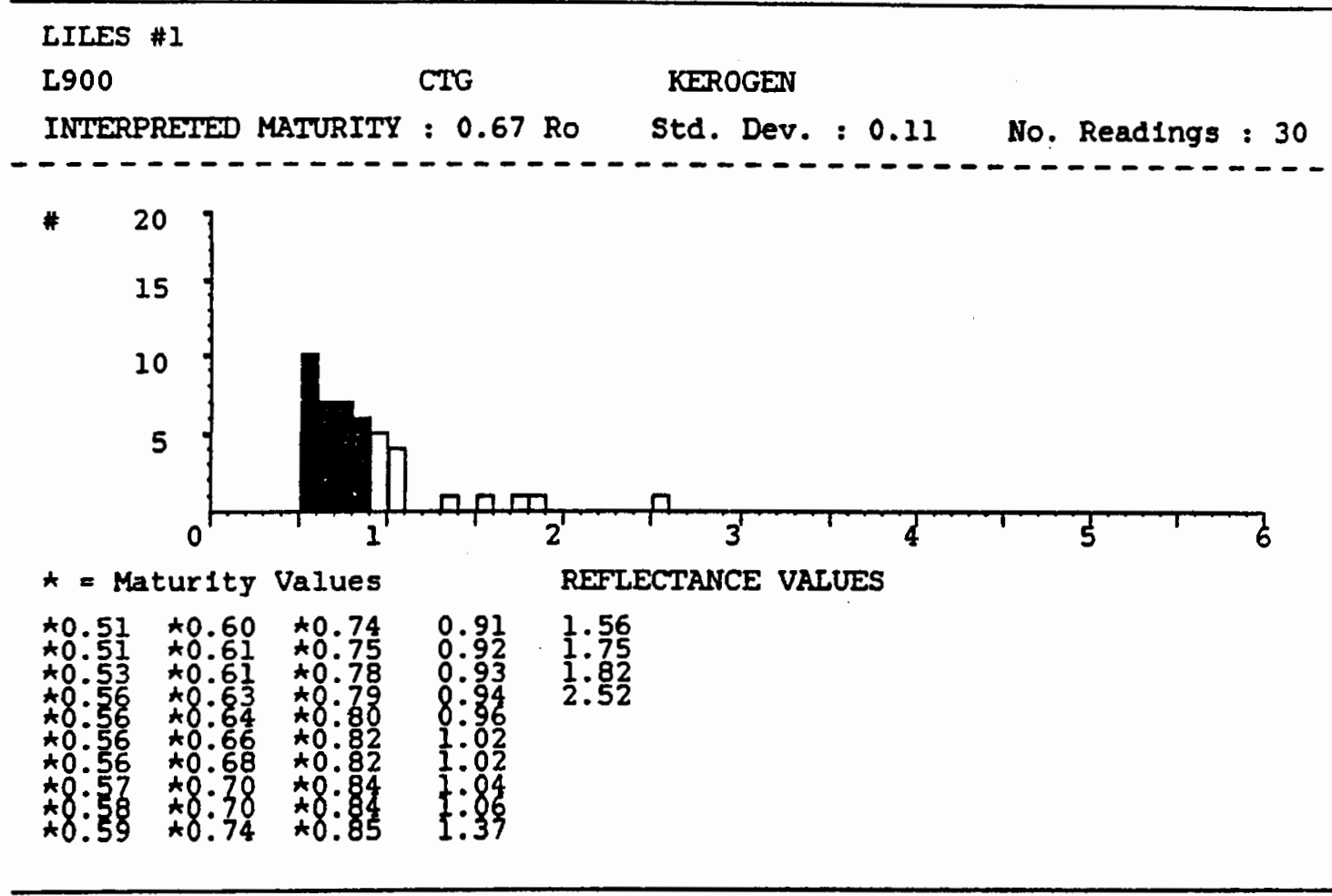

\section{LILES \#I}

L4140 CTG KEROGEN

INTERPRETED MATURITY : 0.68 Ro Std. Dev. : 0.11 No. Readings : 25
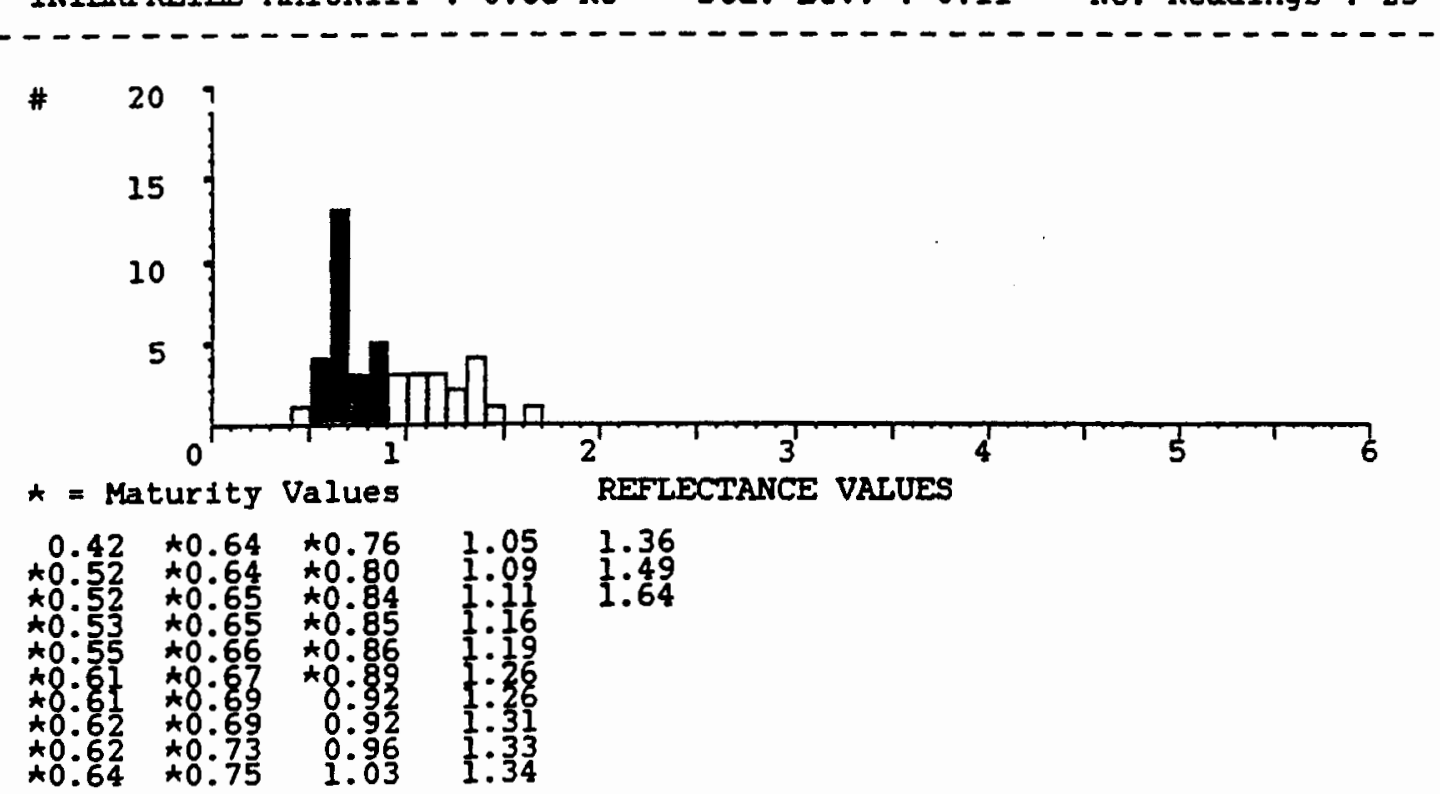


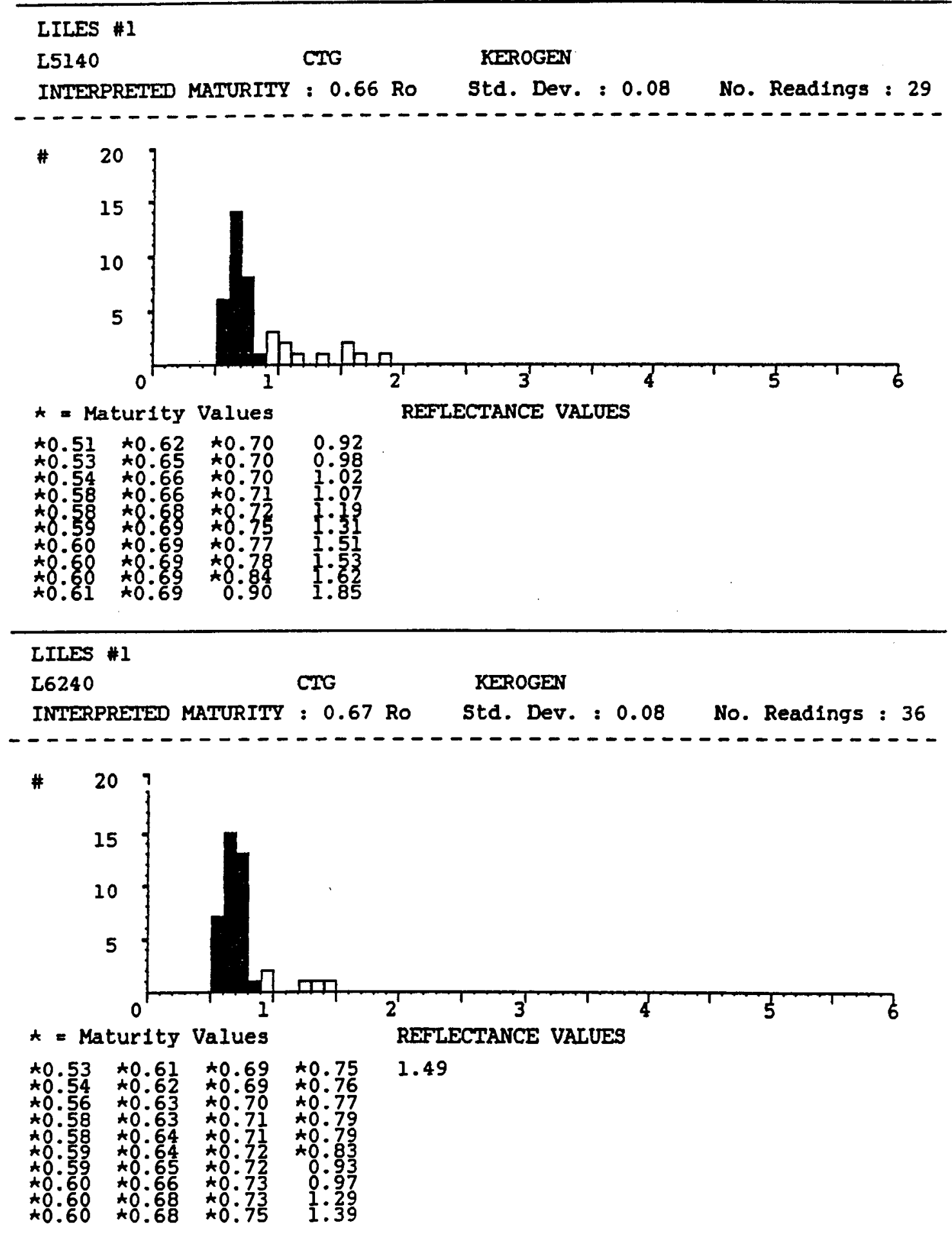




\section{LILES \#I}

\section{L6960 CTG KEROGEN}

INTERPRETED MATURITY : 0.71 Ro std. Dev. : 0.07 No. Readings : 31

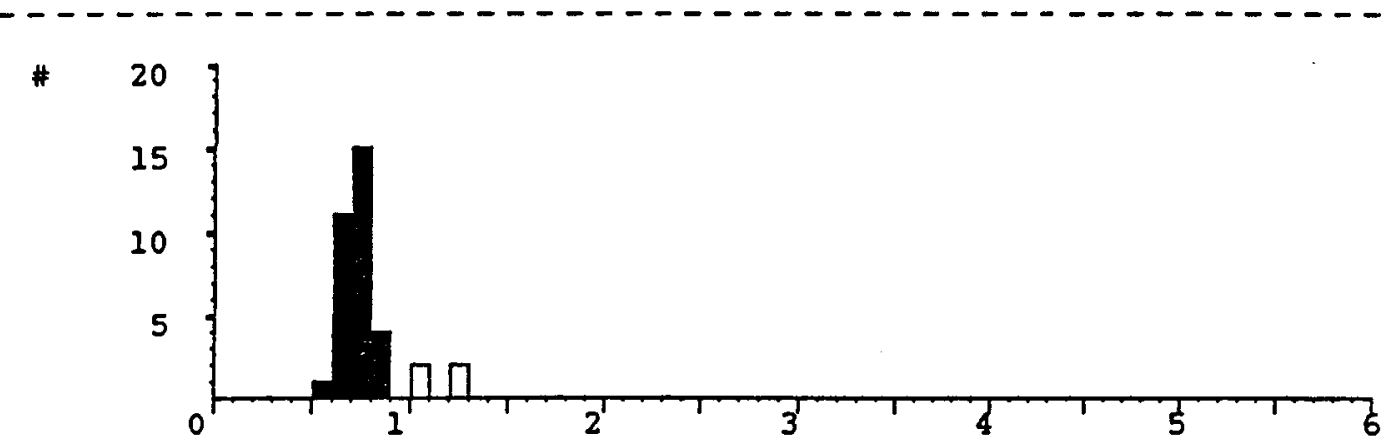

\begin{tabular}{|c|c|c|}
\hline $\begin{array}{l}\star 0.58 \\
\star 0.60 \\
\star 0.61 \\
\star 0.61 \\
\star 0.65 \\
\star 0.655 \\
\star 0.65 \\
\star 0.65 \\
\star 0.65 \\
\star 0.65\end{array}$ & $\begin{array}{l}\star 0.67 \\
\star 0.69 \\
\star 0.70 \\
\star 0.72 \\
\star 0.72 \\
\star 0.73 \\
\star 0.73 \\
\star 0.73 \\
\star 0.73 \\
\star 0.74\end{array}$ & $\begin{array}{l}\star 0.75 \\
\star 0.76 \\
\star 0.77 \\
\star 0.77 \\
\star 0.78 \\
\star 0.79 \\
\star 0.79 \\
\star 0.80 \\
\star 0.80 \\
\star 0.81\end{array}$ \\
\hline
\end{tabular}

\section{SCOTT}

\$1250 CTG KEROGEN

INIERPRETED MATURITY : 0.73 Ro Std. Dev. : 0.08 No. Readings : 18

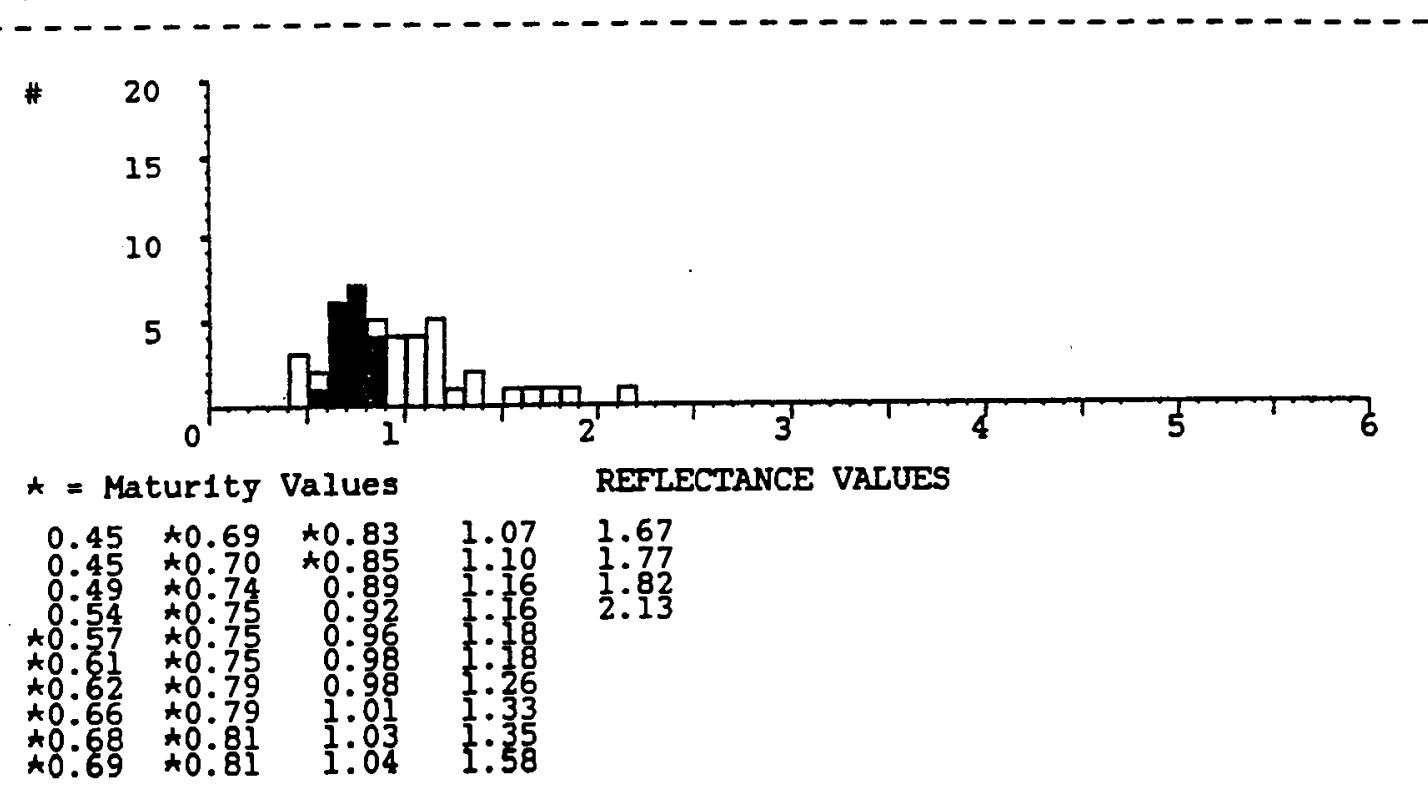




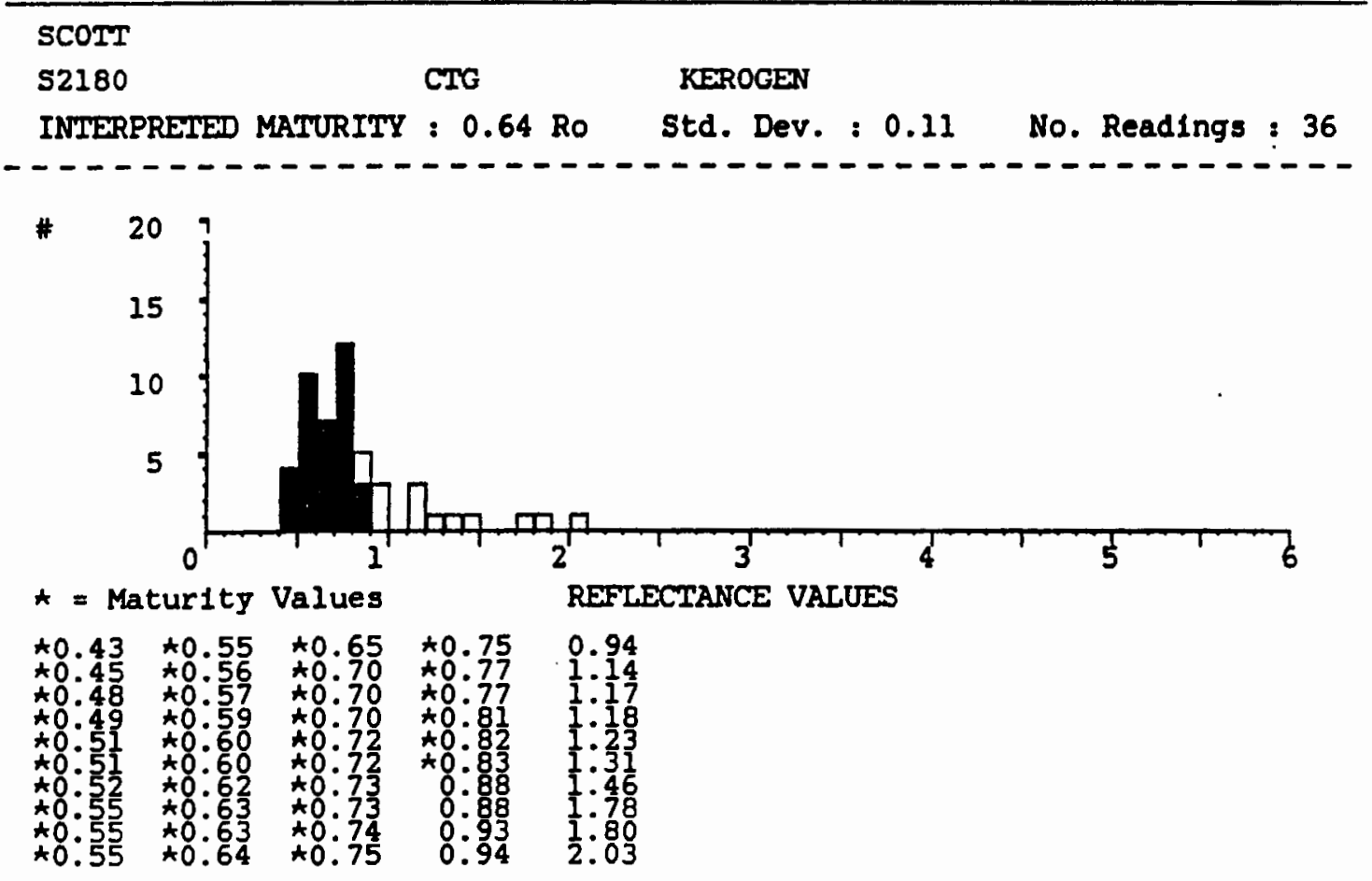

\section{SCOTT}

53080

CTG

KEROGEN

INTERPRETED MATURITY : $0.63 \mathrm{Ro}$ std. Dev. : 0.13 No. Readings : 23

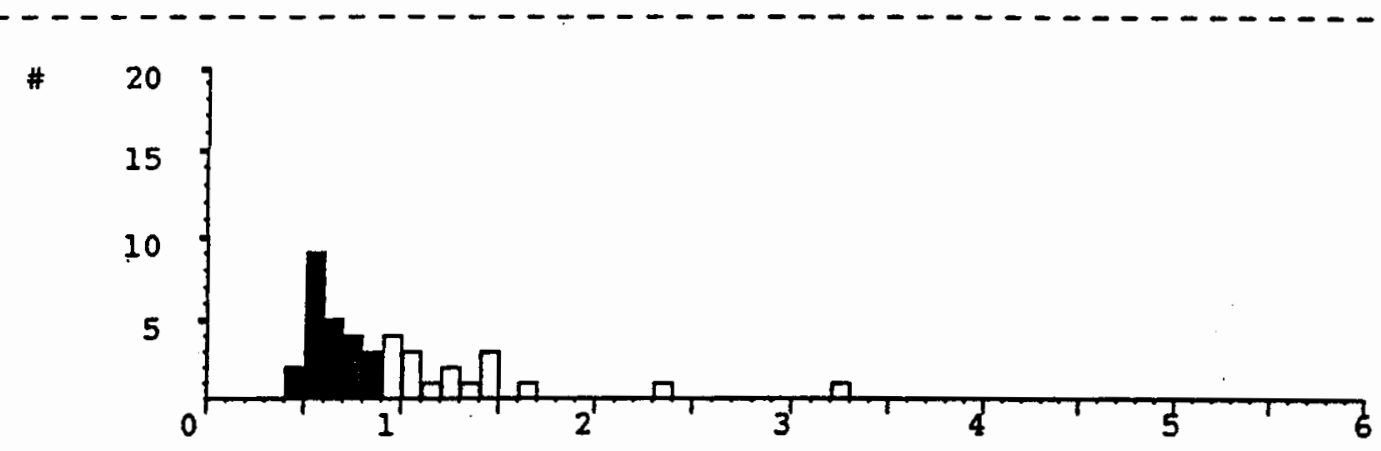

$\star$ = Maturity Values

REFLECTANCE VALUES

$\begin{array}{rrrr}\star 0.45 & \star 0.59 & \star 0.82 & 1.14 \\ \star 0.48 & \star 0.61 & \star 0.84 & 1.22 \\ \star 0.51 & \star 0.63 & \star 0.87 & 1.25 \\ \star 0.51 & \star 0.63 & 0.93 & 1.39 \\ \star 0.52 & \star 0.64 & 0.94 & 1.42 \\ \star 0.52 & \star 0.69 & 0.98 & 1.48 \\ \star 0.52 & \star 0.74 & 0.98 & 1.49 \\ \star 0.54 & \star 0.76 & 1.00 & 1.61 \\ \star 0.55 & \star 0.77 & 1.01 & 2.13 \\ \star 0.56 & \star 0.79 & 1.07 & 3.21\end{array}$




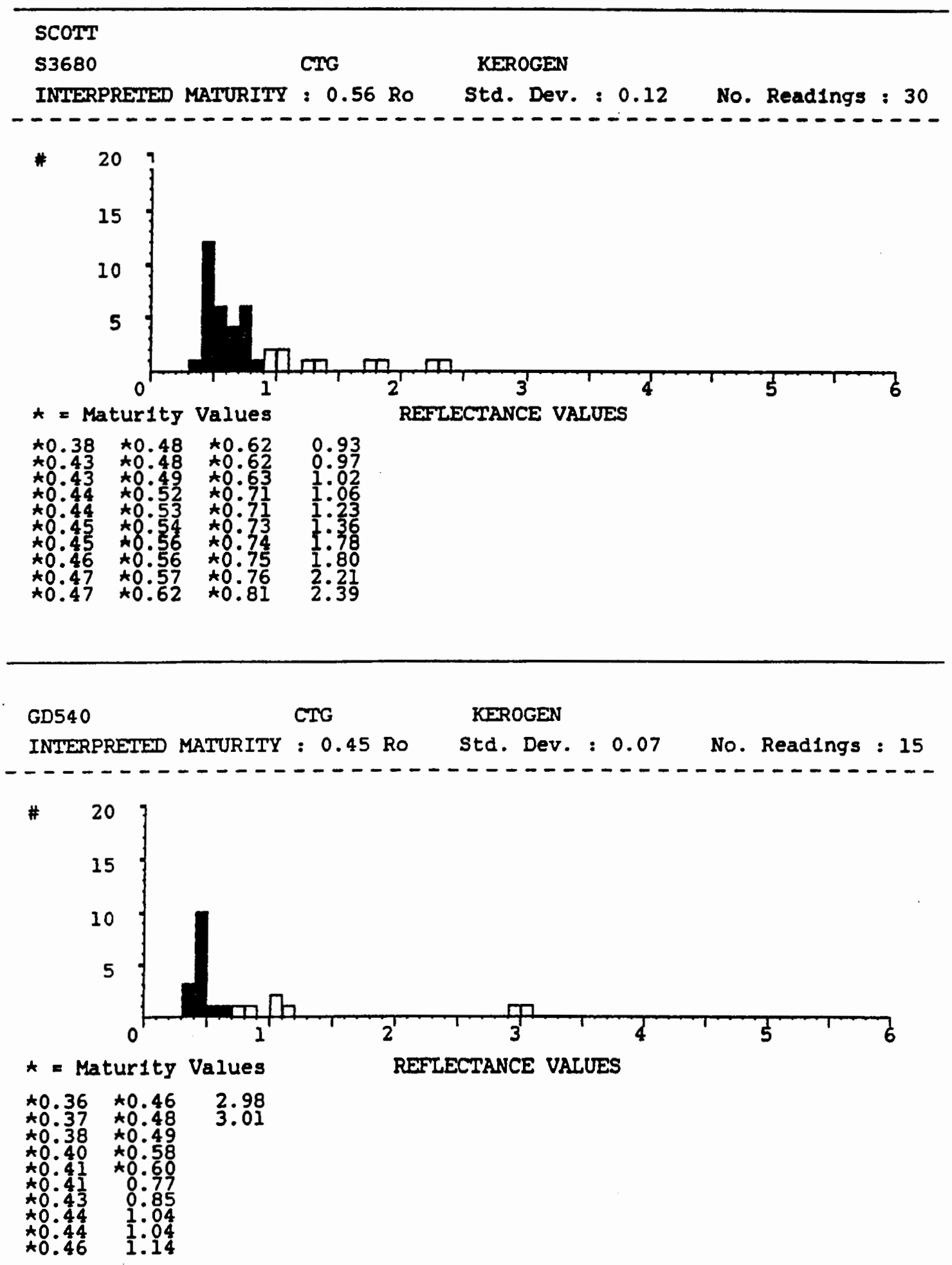




$\begin{array}{llll}\text { GD1380 CTG } & \text { KEROGEN } \\ \text { INIEERPRETED MATURITY : } 0.55 \text { RO } & \text { Std. Dev. : } 0.12 \text { No. Readings : } 24\end{array}$

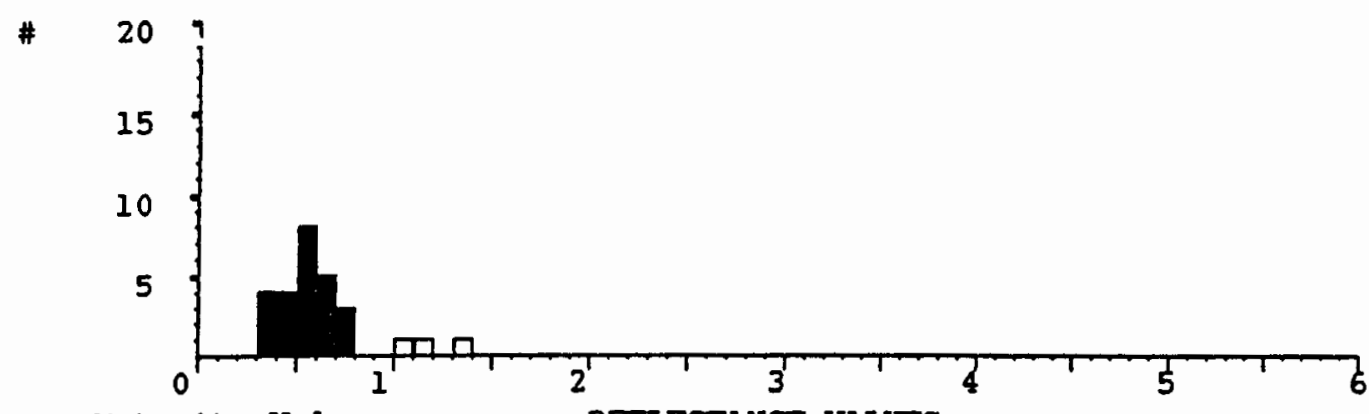

$\star$ = Maturiţ Values

REFLECTANCE VALUES

$\begin{array}{lll}\star 0.35 & \star 0.54 & \star 0.66 \\ \star 0.36 & \star 0.57 & \star 0.71 \\ \star 0.37 & \star 0.57 & \star 0.75 \\ \star 0.37 & \star 0.58 & \star 0.78 \\ \star 0.42 & \star 0.58 & 1.07 \\ \star 0.43 & \star 0.59 & 1.14 \\ \star 0.45 & \star 0.63 & 1.31 \\ \star 0.19 & \star 0.54 & \\ \star 0.53 & \star 0.64 & \\ \star 0.53 & \star 0.65 & \end{array}$

$\star 0.53$

GD3120 CTG KEROGEN

INTERPRETED MATURITY : 0.60 Ro Std. Dev. : 0.06 No. Readings : 29

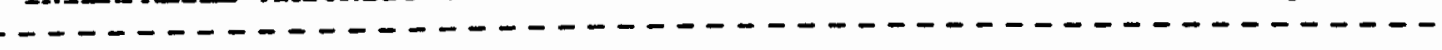

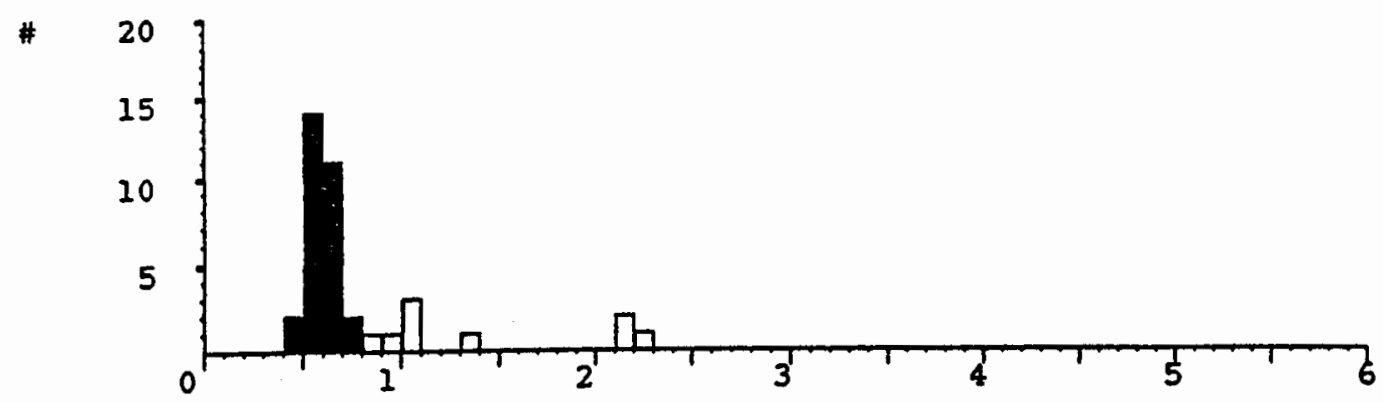

$\star=$ Maturity Values

REFLECTANCE VALUES

$\begin{array}{llll}\star 0.49 & \star 0.58 & \star 0.62 & 0.95 \\ \star 0.49 & \star 0.59 & \star 0.62 & 1.01 \\ \star 0.52 & \star 0.59 & \star 0.64 & 1.03 \\ \star 0.53 & \star 0.59 & \star 0.66 & 1.07 \\ \star 0.55 & \star 0.59 & \star 0.66 & 1.36 \\ \star 0.55 & \star 0.59 & \star 0.66 & 2.15 \\ \star 0.55 & \star 0.60 & \star 0.68 & 2.15 \\ \star 0.57 & \star 0.60 & \star 0.70 & 2.26 \\ \star 0.57 & \star 0.61 & \star 0.71 & \\ \star 0.58 & \star 0.61 & & \end{array}$




$\begin{array}{llll}\text { GH420 CTG } & \text { KEROGEN } \\ \text { INTERRPETED MATURITY : } 0.43 \text { RO } & \text { Std. Dev. : } 0.04 & \text { No. Readings : } 34\end{array}$

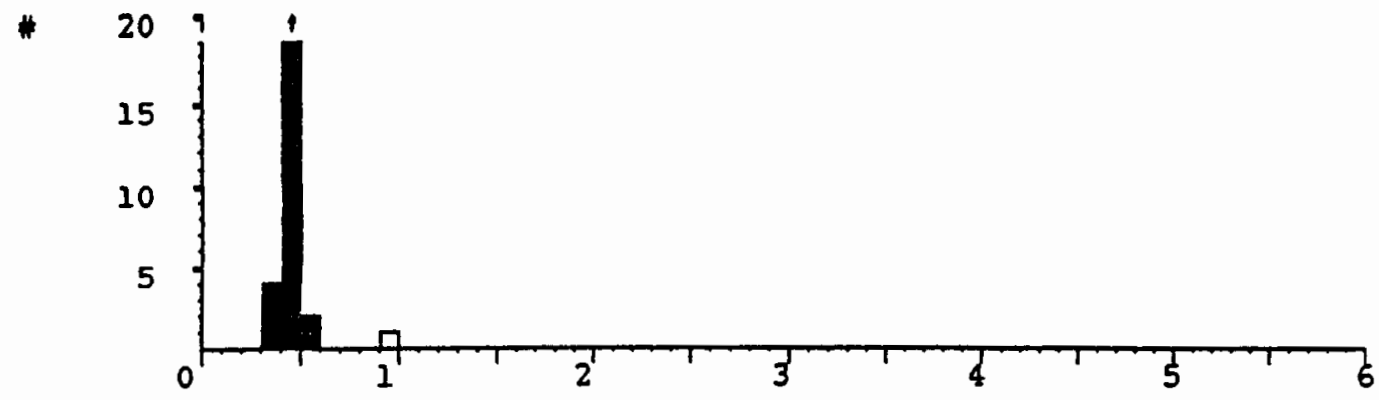

$\star=$ Maturitg Values

REFLECTANCE VALUES

$\begin{array}{llll}\star 0.36 & \star 0.40 & \star 0.43 & \star 0.46 \\ \star 0.37 & \star 0.41 & \star 0.43 & \star 0.46 \\ \star 0.37 & \star 0.41 & \star 0.43 & \star 0.50 \\ \star 0.39 & \star 0.41 & \star 0.44 & \star 0.54 \\ \star 0.40 & \star 0.42 & \star 0.44 & 0.94 \\ \star 0.48 & \star 0.42 & \star 0.45 & \\ \star 0.48 & \star 0.42 & \star 8.45 & \\ \star 0.40 & \star 0.42 & \star 0.45 & \\ \star 0.48 & \star 0.43 & \star 0.45 & \\ \star 0.40 & \star 0.43 & \star 0.46 & \end{array}$

GH1470 CTG KEROGEN

INIERPRETED MATURITY : 0.64 Ro Std. Dev. : 0.08 No. Readings : 12

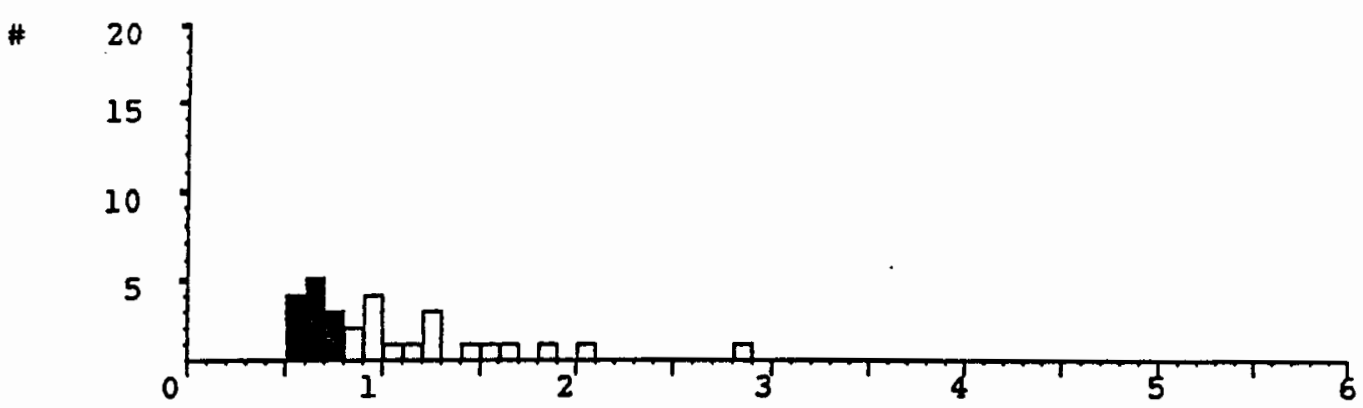

$\star$ = Maturity Values

REFLECTANCE VALUES

$\begin{array}{rrr}\star 0.50 & \star 0.75 & 1.21 \\ \star 0.53 & \star 0.77 & 1.27 \\ \star 0.59 & 0.85 & 1.28 \\ \star 0.59 & 0.86 & 1.40 \\ \star 0.60 & 0.90 & 1.57 \\ \star 0.60 & 0.93 & 1.65 \\ \star 0.65 & 0.93 & 1.85 \\ \star 0.68 & 0.97 & 2.07 \\ \star 0.69 & 1.06 & 2.85 \\ \star 0.71 & 1.13 & \end{array}$




\section{RN90-322 OUTCROP KEROGEN}

INTERPRETED MATURITY : 0.36 Ro? std. Dev. : 0.06 No. Readings : 4
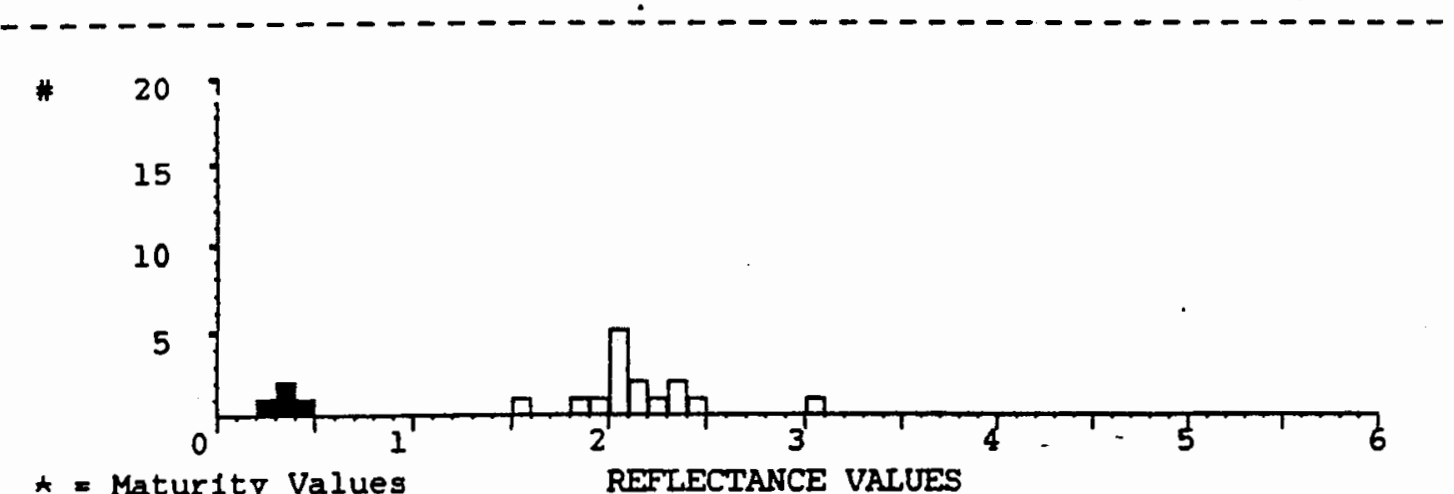

$\begin{array}{rr}\star 0.28 & 2.03 \\ \star 0.35 & 2.07 \\ \star 0.38 & 2.10 \\ \star 0.43 & 2.18 \\ 1.58 & 2.27 \\ 1.89 & 2.32 \\ 1.96 & 2.39 \\ 2.01 & 2.45 \\ 2.02 & 3.03 \\ 2.02 & \end{array}$

OUTCROP KEROGEN
INTERPRETED MATURITY : 0.42 RO Std. DeV.: 0.03 No. Readings : 30
-

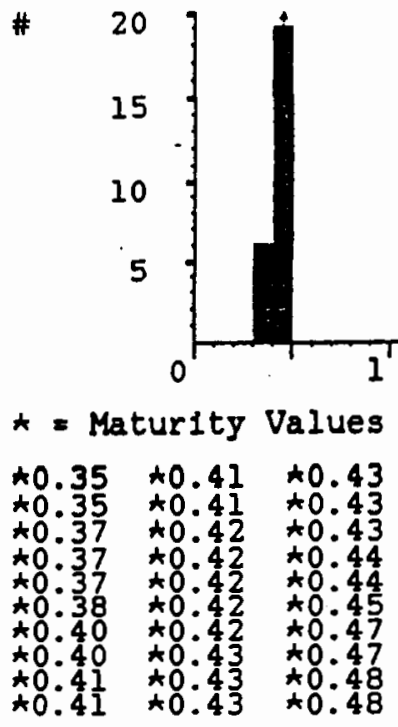




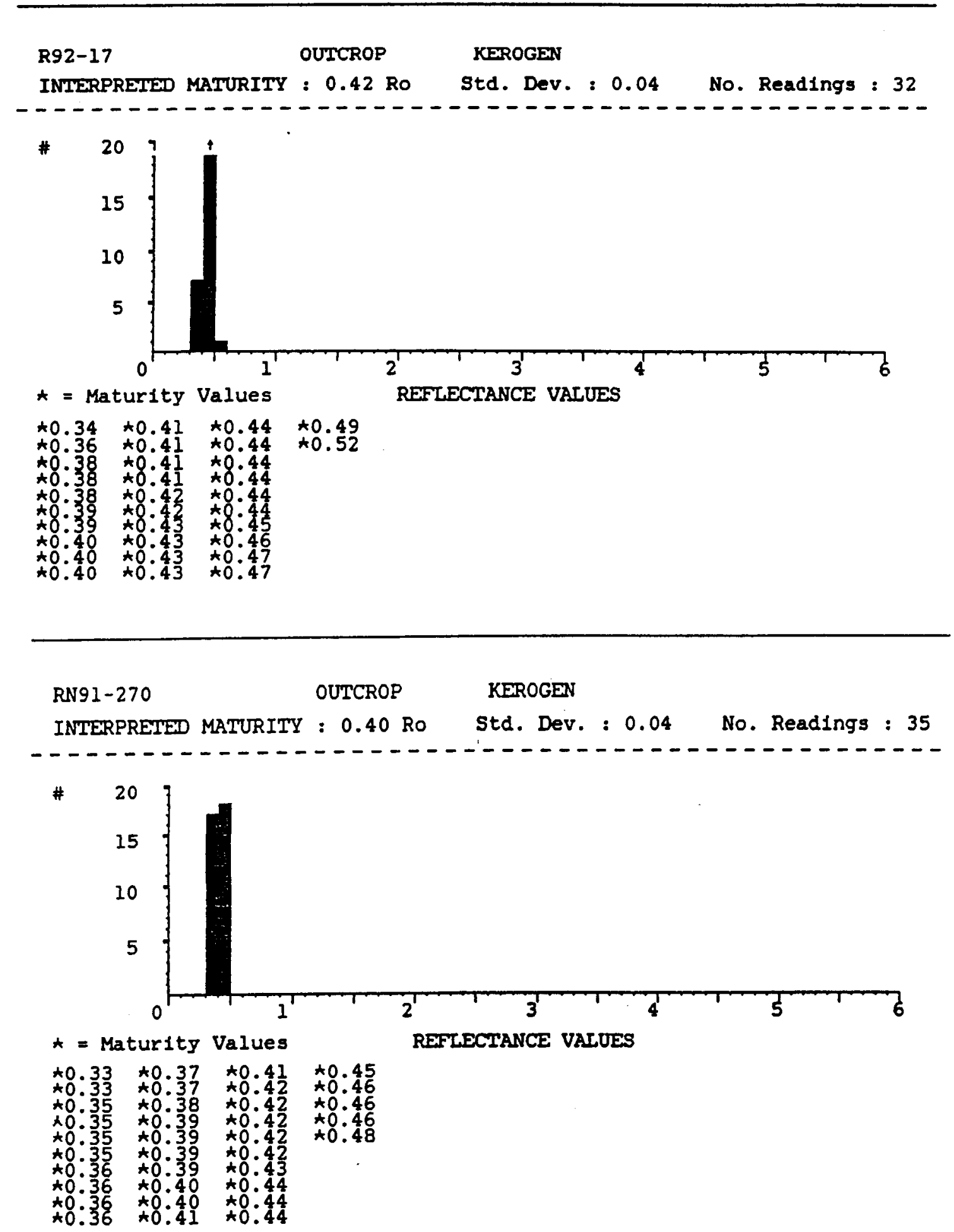




\section{APPENDIX E}

COMPLETE VISUAL ASSESSMENT DATA 


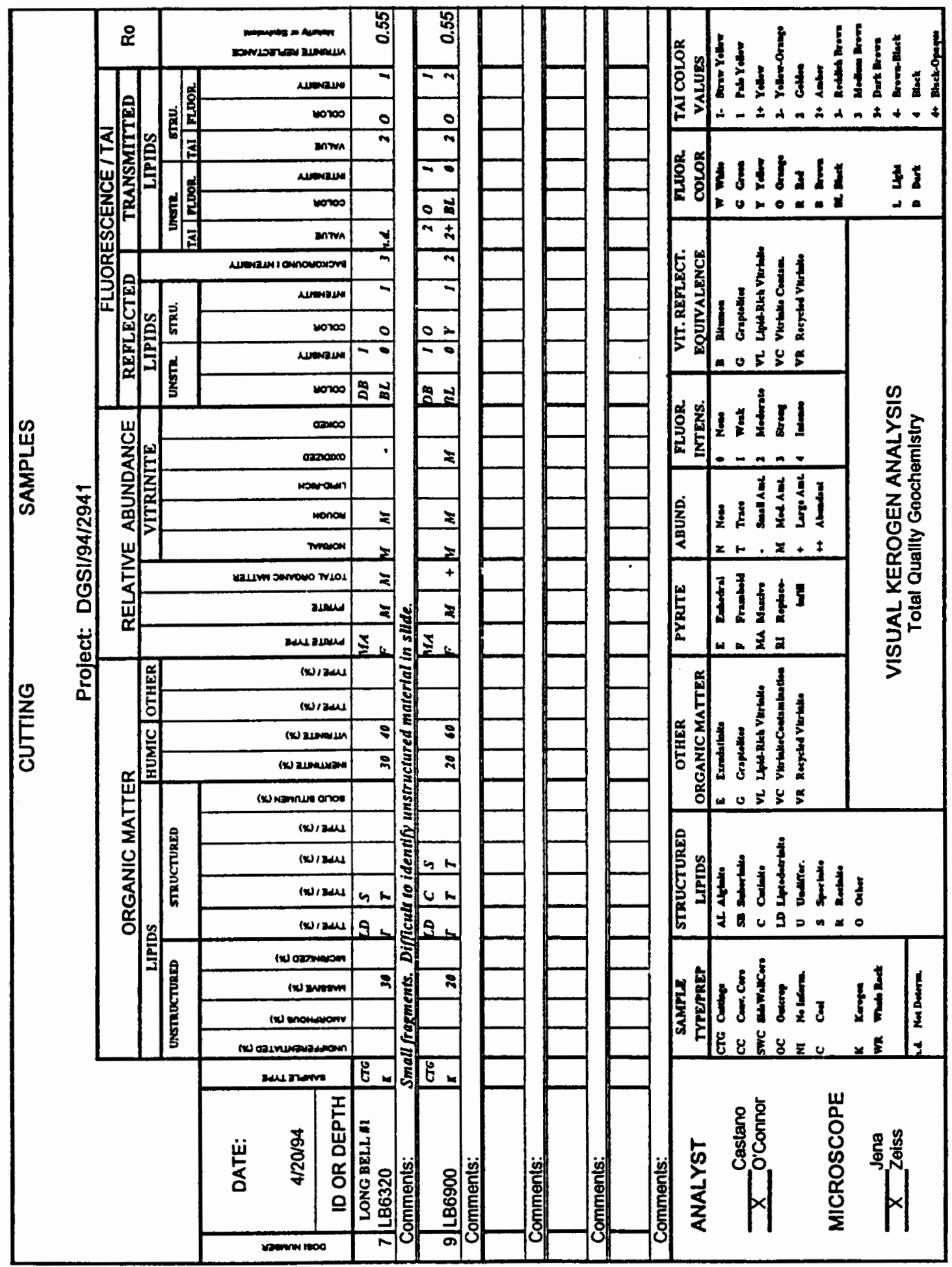




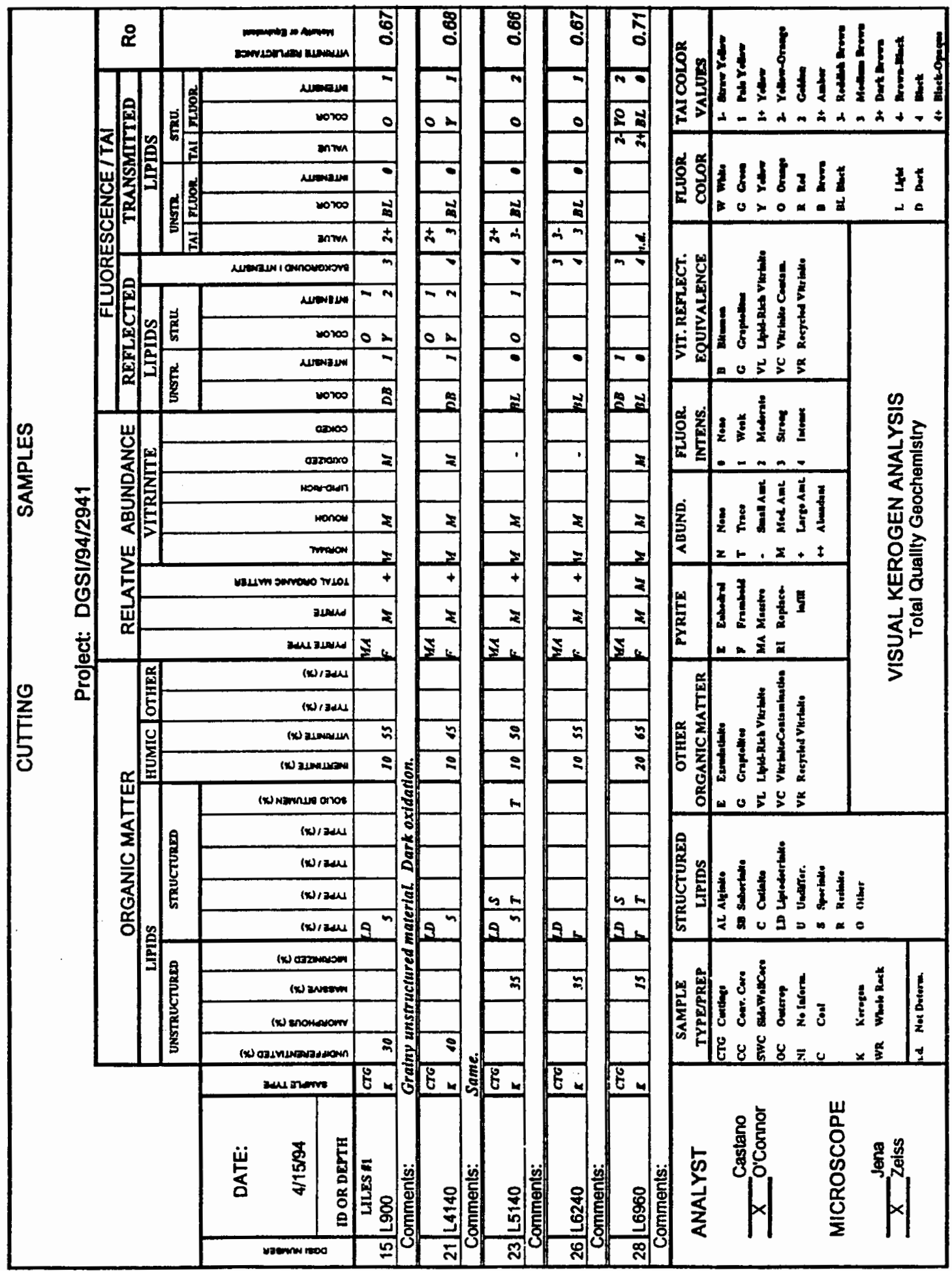




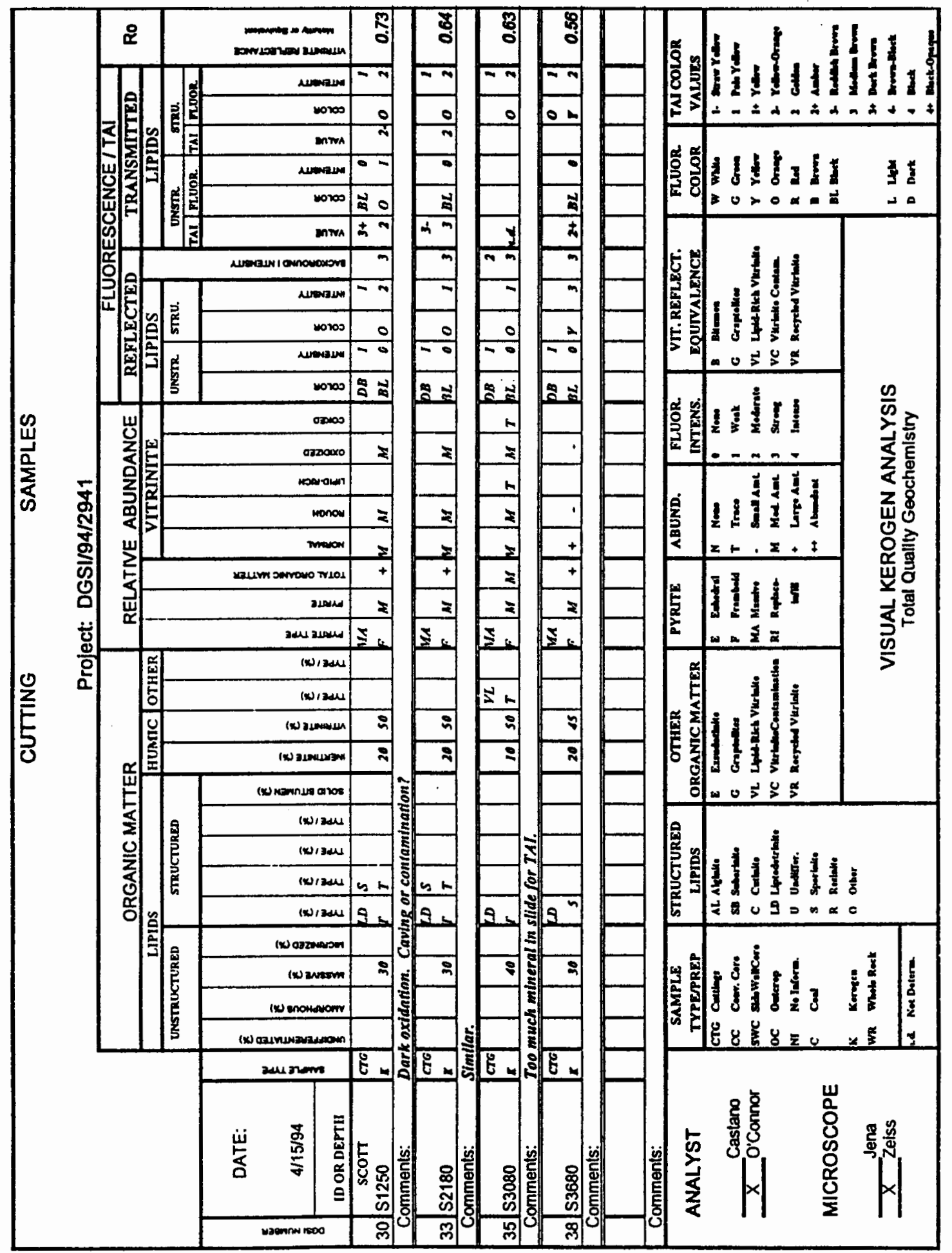




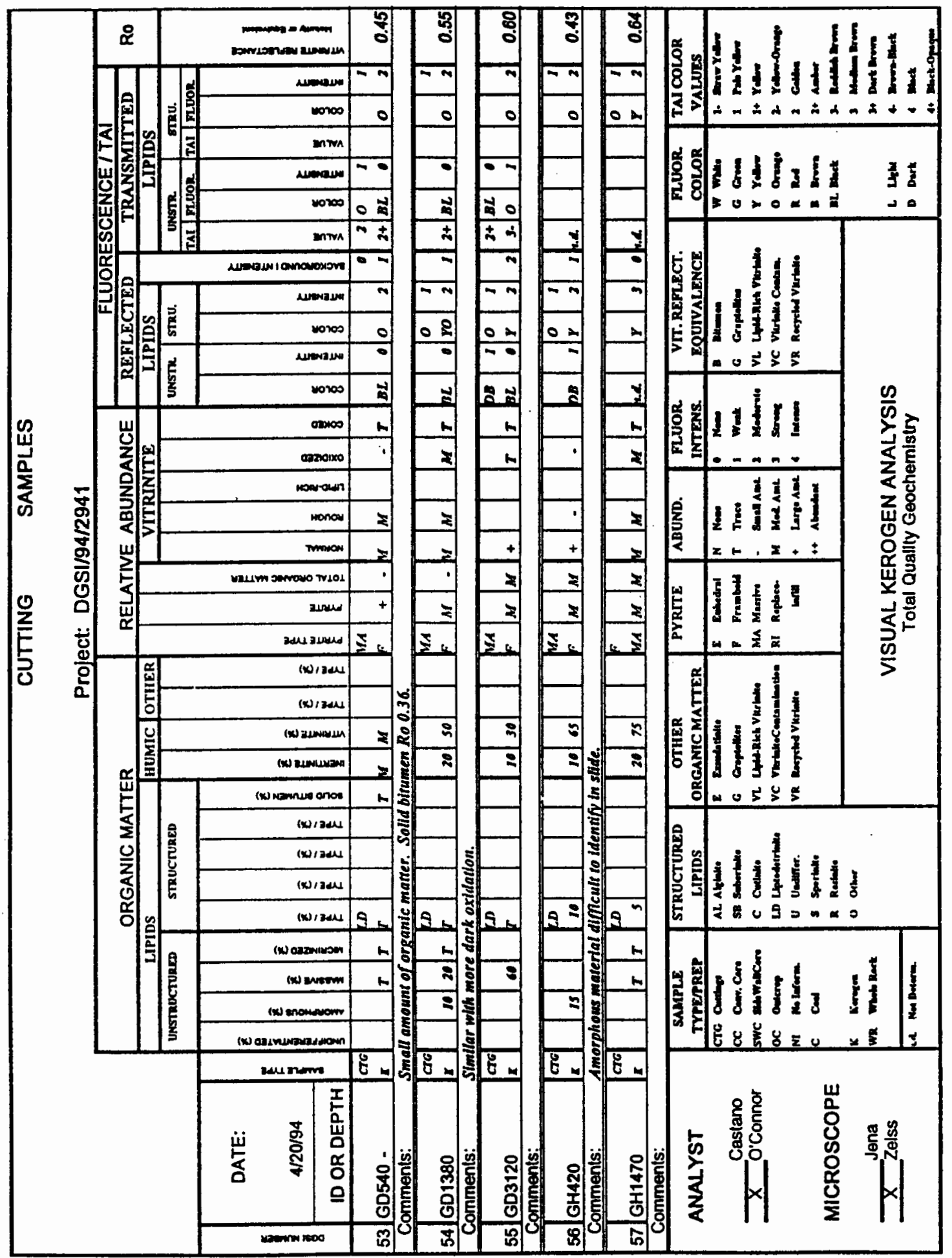




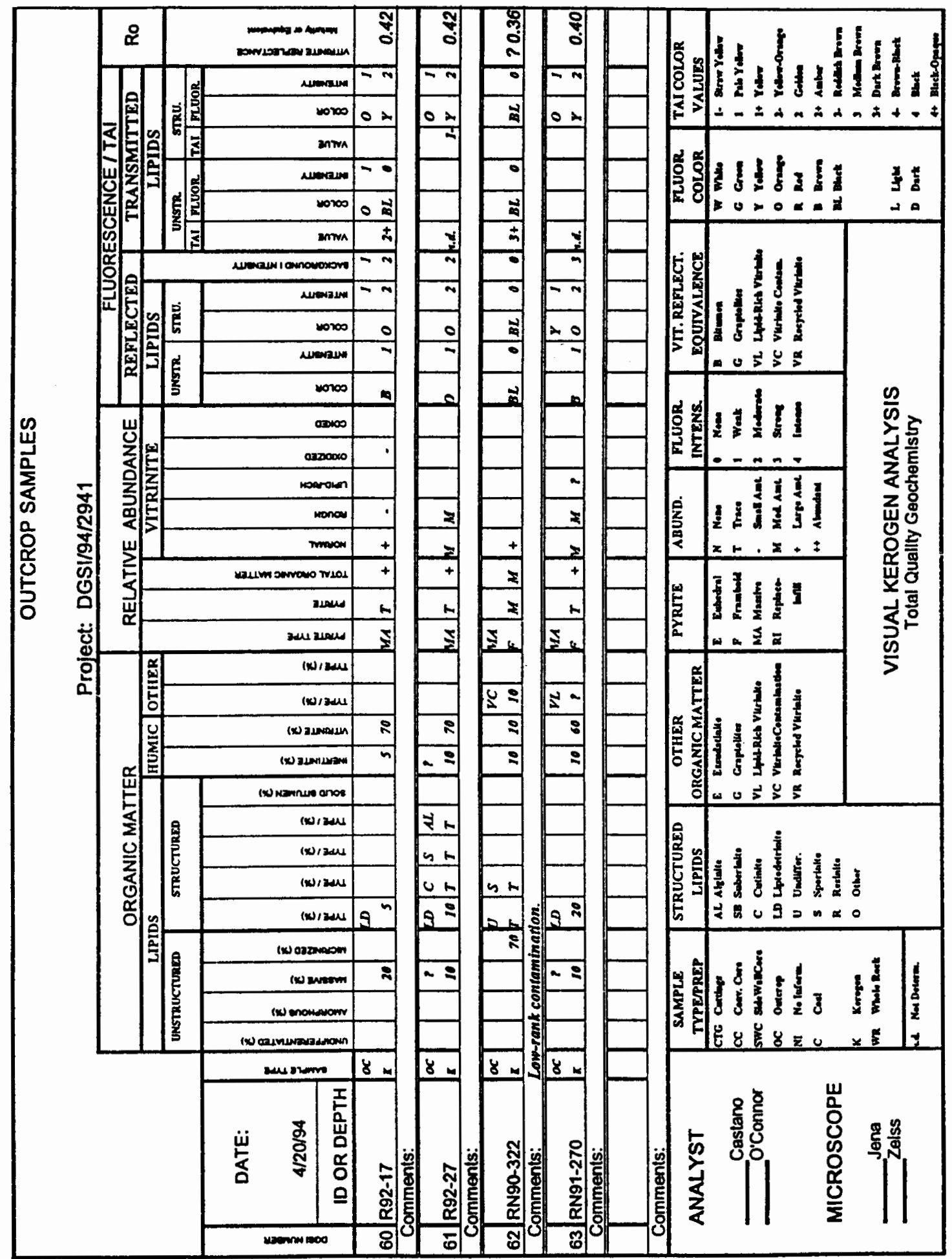

